\title{
The Huqoq Excavation Project: 2014-2017 Interim Report
}

\author{
Jodi Magness, Shua Kisilevitz, Matthew Grey, Dennis Mizzi, \\ Daniel Schindler, Martin Wells, Karen Britt, Ra'anan Boustan, \\ Shana O'Connell, Emily Hubbard, Jessie George, Jennifer Ramsay, \\ Elisabetta Boaretto, and Michael Chazan
}

\begin{abstract}
Excavations at Huqoq in Israel's eastern Lower Galilee are bringing to light a Late Roman synagogue, a medieval public building, and the remains of ancient and modern (pre-1948) villages. In this interim report, we describe the major discoveries of the 2014-2017 seasons, including the extraordinary figural mosaics decorating the synagogue floor. Our discoveries provide evidence of a Galilean Jewish community that flourished through the 5th and 6th centuries C.E.-a picture contrasting with recent claims of a decline in Jewish settlement under Byzantine Christian rule. The possibility that the medieval public building might also be a synagogue has important implications for understanding Galilean Jewish settlement in the Middle Ages, about which almost nothing is known. The excavations also shed light on the last phase of the settlement's long history: the development of the modern village of Yakuk in the 19th through 20th centuries.
\end{abstract}

Keywords: Huqoq; Galilee; mosaics; synagogue; Late Roman; Byzantine; medieval; Mamluk; Ottoman; village

$\mathrm{S}$ ince 2011, a consortium of universities has excavated at Horvat Huqoq (henceforth, Huqoq) in Israel's eastern Lower Galilee, under the direction of Jodi Magness of The University of North Carolina at Chapel Hill with Assistant Director Shua Kisilevitz of the Israel Antiquities Authority and Tel Aviv University (Fig. 1). This report provides an overview of the project's discoveries from 2014 through 2017. ${ }^{1}$

${ }^{1}$ For an interim report on the 2011-2013 seasons, see Magness et al. 2014.

Jodi Magness: Department of Religious Studies, The University of North Carolina at Chapel Hill, CB \#2225, Chapel Hill, NC 27599-3225; magness@email.unc.edu

Shua Kisilevitz: Tel Aviv University, and Israel Antiquities Authority, Jerusalem Region, 2 Betar Street, Second floor, Jerusalem, Israel; shua_kisilevitz@hotmail.com

Matthew Grey: Department of Ancient Scripture, Brigham Young University, Provo, UT 84602; matthew_grey@byu.edu

Dennis Mizzi: Department of Oriental Studies, University of Malta, Msida, MSD2080 Malta; dennis.mizzi@um.edu.mt

\section{Project Rationale}

Early in the 20th century, Heinrich Kohl and Carl Watzinger (1916) surveyed and excavated a number of

Daniel Schindler: Department of World Languages and Cultures, Elon University, Carlton Building 220, 2125 Campus Box, Elon, NC 27244; dschindler3@elon.edu

Martin Wells: Department of Classical and Modern Languages, Austin College, 900 North Grand Avenue, Suite 61614, Sherman, TX 75090; mawells@austincollege.edu

Karen Britt: School of Art and Design, Western Carolina University, 356 Pelohi Cove Road, Bryson City, NC 28713; kbritt@wcu.edu

Ra'anan Boustan: Program in Judaic Studies, Princeton University, 101 Broadmead Street, Princeton, NJ 08540; rboustan@princeton.edu

Shana O'Connell: Classics Department, Howard University, Locke Hall 254, 2441 Sixth Street NW, Washington, DC 20059; shana.oconnell@howard.edu

Emily Hubbard: 19 Russell Street, Toronto ON, M5S, Canada; emily.hubbard@mail.utoronto.ca 


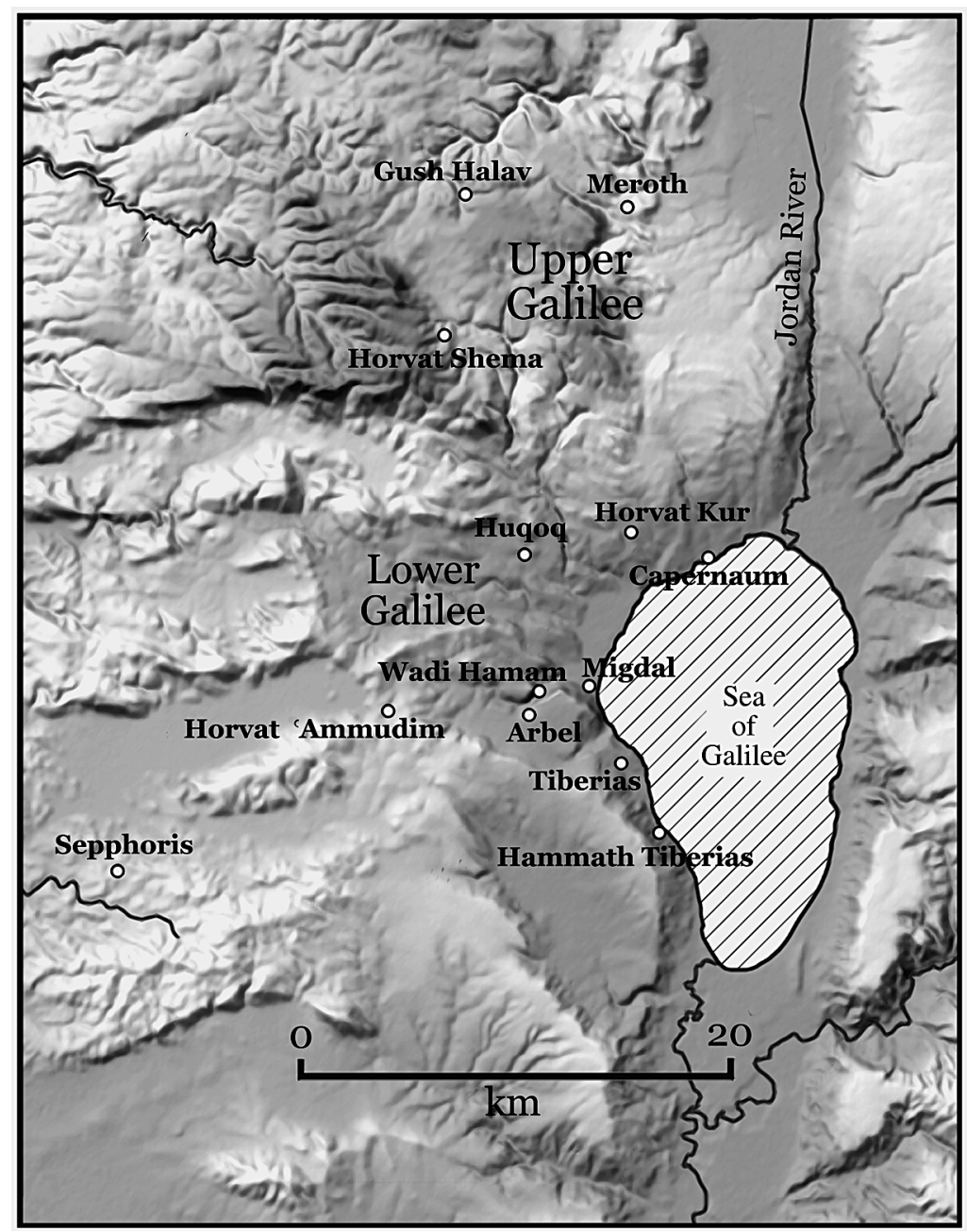

Fig. 1. Map of the Galilee. (Prepared by R. Mohr; base map courtesy of NordNordWest [http://creativecommons.org/licenses/by-sa/3.0/])

Jessie George: Department of Geography, University of California, Los Angeles, Los Angeles, CA 90095; jmgeorge@ucla.edu

Jennifer Ramsay: Department of Anthropology, The College at Brockport, State University of New York, 350 New Campus Drive, Brockport, NY 14420; jramsay@brockport.edu

Elisabetta Boaretto: DANGOOR-Research Accelerator Mass Spectrometry (D-REAMS) Laboratory, Weizmann Institute of Science, Rehovot 7610001, Israel;

Elisabetta.Boaretto@weizmann.ac.il

Michael Chazan: Department of Anthropology, University of Toronto, 19 Russell Street, Toronto M5S2S2, Canada; mchazan@chass.utoronto.ca ancient synagogues in Galilee, which they dated to the 2nd and 3rd centuries C.E. on the basis of comparisons with Roman temples in Syria and Asia Minor. The best example of these buildings - which became known as Galilean-type synagogues-is the synagogue at Capernaum, ca. $5 \mathrm{~km}$ from Huqoq. It is a monumental basilica, entered through three doorways in the south (short) wall, with the interior of the hall surrounded on the east, west, and north sides by a stylobate supporting columns on pedestals.

In 1929, Eleazar Sukenik and Nahman Avigad excavated the apsidal synagogue at Beth Alpha in the Jordan Valley. Soon thereafter, Sukenik (1934) published a typology assigning Galilean-type synagogues to the 2nd and 3rd centuries C.E. and Byzantine-type synagogues with 
an apse (such as Beth Alpha) to the 5th and 6th centuries. The typology was later expanded by Erwin Goodenough (1953-1968 1: 178-267) and Michael Avi-Yonah (1961), who added a Transitional (broad house) type, dated to the 4th century (such as Hammath Tiberias).

Magness undertook excavations at Huqoq to clarify the chronology of Galilean-type synagogues, which she believes date to the 4 th century C.E. and later, and thus contemporary with Transitional- and Byzantine-type synagogues. The earlier dating-which is still favored by many archaeologists in Israel and elsewhere-is based on stylistic considerations, whereas Magness's chronology is based on the archaeological material (mainly pottery and coins) associated with the construction of these buildings. Magness believes that before the 4th century, synagogue buildings in Palestine were relatively modest structures undistinguished by Jewish decorative motifs and without permanent liturgical furniture, such as Torah shrines. ${ }^{2}$ In Magness's opinion, the appearance of monumental synagogue architecture and art in the 4th century C.E.- - and especially from the later 4th century on-should be understood within the context of the rise of Christianity, which was legalized by Constantine in 313 C.E. In other words, Jews began building monumental synagogues around the same time that Christians began building monumental churches.

The linear evolutionary model represented by the traditional typology has been challenged by new and ongoing discoveries and by reevaluations of the existing archaeological evidence. The biggest challenge comes from Capernaum, where Franciscan archaeologists have conducted excavations since the late 1960s. Below the paving stones of the floor of the synagogue and adjacent courtyard, they have found over 25,000 small bronze coins and large quantities of pottery dating to the 4 th and 5 th centuries C.E. The latest of these finds date to approximately 500 C.E., indicating that the synagogue was built no earlier than the beginning of the 6th century-centuries later than previously thought. ${ }^{3}$ Because Capernaum is always cited as the classic example of a Galilean synagogue, this discovery removes the cornerstone of the traditional typology.

The discoveries at Capernaum have created an ongoing controversy in ancient synagogue studies (see Tsafrir 1989; Ma'oz 1999; Foerster 2004; Amit 2007; and Arubas and Talgam 2014). To account for the 4 th- and 5th-century pottery and coins under the floors, some scholars argue that the Capernaum synagogue originally was built

\footnotetext{
${ }^{2}$ An exception is the stone table from the Migdal synagogue, which is decorated with motifs alluding to the Jerusalem temple (see Avshalom-Gorni and Najar 2013).

${ }^{3}$ For discussions with references, see Magness 2001: 18-26; 2012.
}

in the 2 nd or 3 rd century c.E. but later was destroyed and rebuilt. However, the published reports give no indication of an earlier phase or evidence that the synagogue was rebuilt. This argument also fails to account for the dating of other Galilean-type synagogues to the 4th-6th centuries. $^{4}$

The inescapable conclusion is that the traditional typology can no longer be considered valid. The limited data available in the first half of the 20th century supported the typology, but today we have a wealth of additional information and many more excavated synagogues. The differences between the traditional synagogue types are due not to different dates but other factors, such as regional traditions and local building materials, congregational or donor preferences, and perhaps different movements or liturgies within Judaism. ${ }^{5}$ For example, Galilean-type synagogues cluster in the area to the north and northwest of the Sea of Galilee, with a related type characteristic of the Golan (see Ma`oz 1981; 1993). Broad house buildings (the Transitional type) are concentrated especially in southern Judaea (the Darom or Daroma): Eshtamoa', Khirbet Susiya, Ma'on, and Horvat 'Anim (all without an internal colonnade and with entrances in the eastern broad wall), and 'Ein Gedi. ${ }^{6}$ Although Golan synagogues resemble the Galilean type, they differ in having one doorway instead of three in the main wall (except for edDikke) and typically are decorated with a greater number and variety of figured reliefs (especially lions and eagles) (Macoz 1981: 101-2, 110). Furthermore, different types are attested even within the same region-for example, the broad house synagogues at Khirbet Shema' (Meyers, Kraabel, and Strange 1976; Magness 1997) and Horvat Kur (Zangenberg et al. 2013a; 2013b) in Galilee.

The ongoing debate over synagogue chronology has been sharpened by the recent work of Uzi Leibner, who claims that Jewish settlement in the eastern Lower Galilee experienced a dramatic decline beginning in the mid-4th century C.E., precisely when it appears the local Jewish

\footnotetext{
${ }^{4}$ See, e.g., the Galilean-type synagogue at Gush Halav (Meyers, Meyers, and Strange 1990; Magness 2001: 3-18); and the Galilean-type synagogue at Nabratein (Meyers and Meyers 2009; Magness 2010). Also see Spigel 2016; for a response, see Schindler 2017: 46-47, n. 96; 82 , n. 17.

${ }^{5}$ E.g., "[W]hile a regional and chronological distribution of synagogue types is apparent, these 'types' in no way reflect a strict geographic or chronologic typology" (Fine and Meyers 1997: 119-20). For a discussion, see Levine 2005: 319-26, which states, "[T]he linear approach equating each type of building to a specific historical period can rightly be put to rest. Diversity reigned in synagogue architecture and art, as it did in other dimensions of synagogue life" (2005: 322).

6 See Amit 1995 (at Ma'on, internal supports were added to the hall in a second phase). For 'Ein Gedi, see Barag 1993. For a recent study of the southern synagogues, see Werlin 2015.
} 
population started to build monumental synagogues. ${ }^{7}$ Underlying Leibner's claim is the assumption that Jews suffered under Christian rule, a view influenced by literary sources, such as the writings of the Church Fathers and Late Roman legislation:

If these [Galilean-type] synagogues were indeed built two or three hundred years later than the period during which their architectural style is known to have flourished, then the standard art-historical method of stylistic dating would be problematic, to say the least. Furthermore, adopting the late chronology [of Magness] would leave us with no synagogues from the 2 nd to early 4th c., the heyday of the Galilean Jewish community, and would date them instead to an era characterised by the sources as one of a declining Jewish population suffering from oppression under a Christian regime. (Leibner 2010: 223)

The discoveries at Huqoq contradict this picture by providing evidence of a monumental Galilean-type synagogue that was erected in the early 5 th century and a prosperous Jewish settlement that flourished through the 6th century. The following is a description of these discoveries, focusing on the 2014-2017 excavation seasons. ${ }^{8}$ The site of Huqoq is located on a limestone outcrop, with multiple limestone and dolomite formations to the north and surface basalt to the south. All of the pre-medieval structures and nearly all of the medieval ones are constructed of limestone, with basalt incorporated in the Late Roman synagogue's foundations, while basalt was used for the modern village houses, with recycled limestone elements from earlier buildings.

\section{Area 2000: The Ancient Village}

From 2011 to 2014, Chad Spigel of Trinity University (San Antonio, TX) supervised the excavations in Area 2000, which lies to the east of Area 3000 (the synagogue) and is not covered by the ruins of the Ottoman village of Yakuk. ${ }^{9}$ The goal in excavating Area 2000 was to uncover part of the ancient village to provide a context for understanding the community that constructed the synagogue. Altogether, nine squares were opened in Area 2000 (Figs. 2, 3). ${ }^{10}$ Excavations in Area 2000 ceased after

\footnotetext{
7 See Leibner 2004; 2009a; 2009b; 2010; Ben David 2005; and Leibner and Ben David 2014. For responses to Leibner, see Magness 2001; 2009; 2012; Magness and Schindler 2015; and Lapin 2017.

${ }^{8}$ For preliminary reports on these seasons, see Magness et al. 2016a; 2016b; 2017; 2018.

9 The phasing and chronology presented here are based on Schindler 2017: 143-59.

10 Two squares were opened in 2011 (SE 7/7, SE 7/8); two squares in 2012 (SE 7/6, SE 6/7); two squares in 2013 (SE 6/6, SE 6/8); and three squares in 2014 (SE 6/5, SE 5/5, SE 5/6). No floors or walls were
}

2014, since which time the area has been backfilled and the project's resources directed to Area 3000. ${ }^{11}$

By the end of 2013, we had uncovered two distinct domestic units (Units 1,2) separated by a common wall (W212). Both structures have at their core two rooms, one behind the other: Unit 1 (the western unit) consists of Rooms 1 and 2 (separated by W217), and Unit 2 (the eastern unit) consists of Rooms 3 and 4 (separated by W226). The main entrance to Unit 1 was through a doorway in the south wall (W208), composed of a nicely hewn threshold stone and two large stone doorposts. The main doorway into Unit 2 was not found, as the south wall is covered by a balk. Additional rooms surround Units 1 and 2 to the west (Room 5), north (Rooms 7, 8), and east (Room 9 [perhaps an alley?]), and on the northernmost part of the excavated area (Rooms 6a/b, 10, 11 [only the southeast corner of which was exposed, bounded by W228 and W229]).

The walls of the units are constructed of roughly worked or unworked fieldstones laid in two rows, with one face made of fieldstones and roughly hewn stones arranged as headers, and the other face of small- and medium-sized fieldstones. Most of the walls are well preserved, some to a height of over $2.0 \mathrm{~m}$. The floors are of compacted plaster or compacted dirt with plaster flecks. There are no signs of destruction in Area 2000. Instead, Units 1 and 2 and the surrounding rooms (5-9) were abandoned and gradually collapsed, as suggested by a layer of dirt that accumulated on top of the floors. This accumulation above the floors seems to include the collapse of the roofs (there is no evidence of a second story), as indicated by the presence of artifacts, including grinding stones and a roof roller, which crashed onto the floors. After the roofs collapsed, the walls gradually tumbled down.

Different floor levels in abutting rooms in Area 2000, evidenced by the elevations of thresholds for doorways, create a confusing stratigraphic picture. For example, in Unit 2 a doorway with finely hewn threshold blocks in W226 provided access from Room 3 to Room 4. A threshold for a doorway in W222 could have provided access from Room 4 to Room 8 to the north. However, the threshold is approximately $0.60 \mathrm{~m}$ above the floor level in Room 4, and $0.35 \mathrm{~m}$ above the floor level in Room 8 , without any sign of steps. It is possible that the threshold was associated with later floors at higher elevations in Rooms 4 and 8, although no evidence of such floors was

reached in the westernmost square (SE 6/5), which was excavated for only a short time in 2014 .

${ }^{11}$ In 2017, the balks separating Squares $5 / 5,5 / 6,6 / 5$, and $6 / 6$ were removed before the area was backfilled. The removal of the balk between Rooms 10 and 11 indicated that W235 and W236 seem to be a single massive wall instead of two separate walls. 


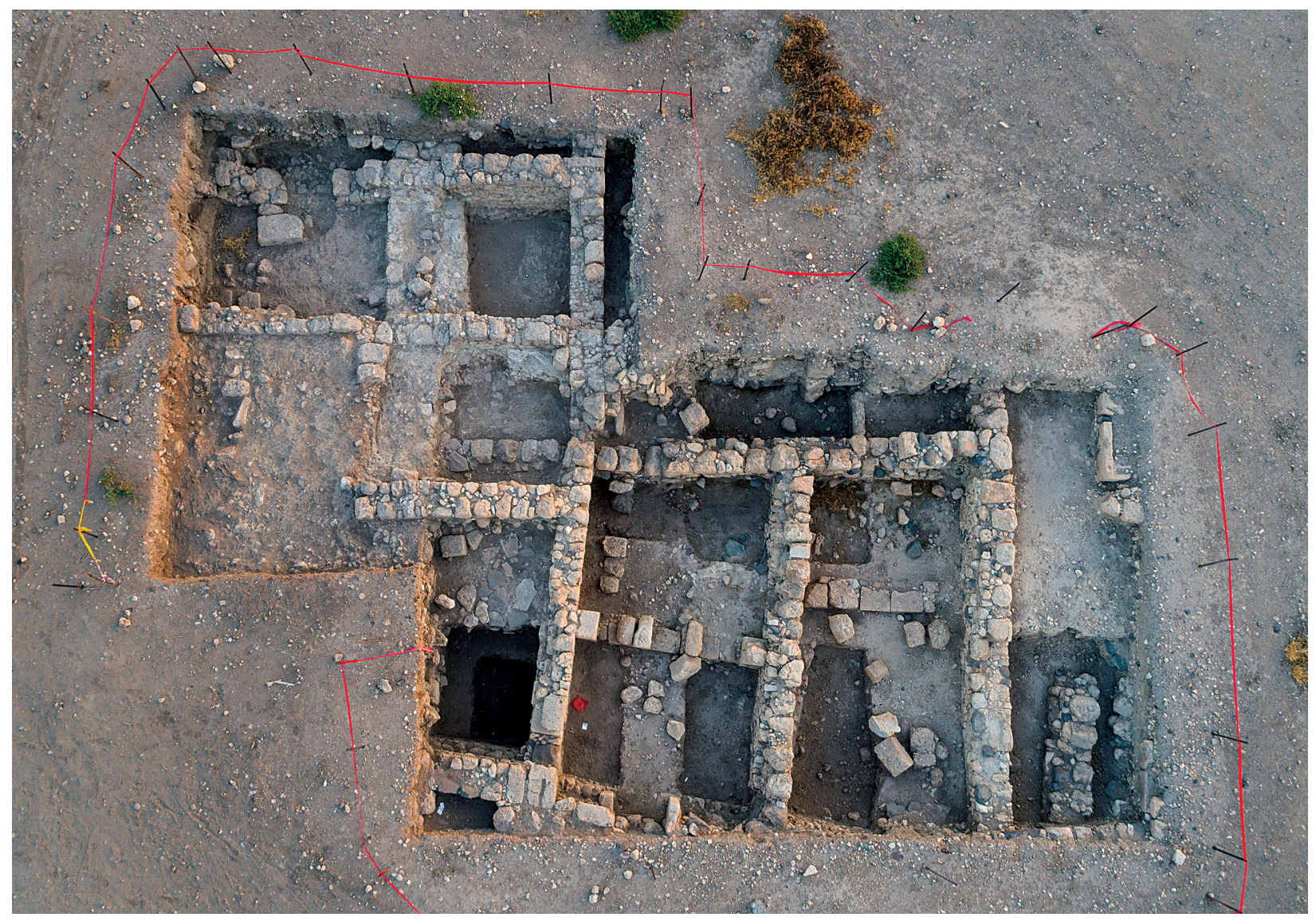

Fig. 2. Aerial view of Area 2000 (north at top). (Photo by SkyView Photography; courtesy of the Huqoq Excavation Project)

discerned in the excavations. Indeed, only one floor was found in every room in Area 2000, with the exception of Rooms $6 \mathrm{~b}$ and 10 . The floor levels in the surrounding rooms (5-10), however, were over $0.30-0.50 \mathrm{~m}$ higher (ca. $27.00 \mathrm{~m}$ ) than those in Units 1 and 2, with the floors in the latter sharing a common elevation of ca. $26.50 \mathrm{~m}$. In addition, the foundations of W223 and W211 are nearly $2 \mathrm{~m}$ below the floor in Room 5, and no other surfaces or floors were discovered in this room. Only Rooms $6 \mathrm{~b}$ and 10 have clear evidence of multiple resurfacings and later occupation extending into the Early Islamic period. That the rooms surrounding Units 1 and 2 were constructed slightly later is borne out by the pottery and coins.

Four phases of construction and/or occupation were identified in Area 2000:12

12 The strata presented for both Areas 2000 and 3000 in this report are provisional. A stratigraphic framework for the entire site will be provided in the final report.
Stratum 1: earlier walls likely dating to the Hellenistic period (W216 [Room 3], W221 [Room 9]); ;

Stratum 2: late 4th/5th-6th-century C.E. construction and occupation of Units 1 and 2 (Rooms 1-4) and Rooms 7-9; the original construction phase of Rooms 5,6 , and 10 ;

Stratum 3: abandonment of Units 1 and 2; a 6th-century construction phase in Rooms 5, 6, and 10, with occupation continuing until the Early Islamic period; and Stratum 4: 12th-13th-century walls (W201, W202, W220) constructed in Room 9. ${ }^{14}$

\footnotetext{
13 The dating of these walls is based on the predominantly Hellenistic pottery found in the fills surrounding them, as well as their different orientation in relation to the 5th-century structures under which they were sealed. However, as no associated surfaces were excavated, the dating of these walls is tentative.

14 The elevation of the walls indicates that their associated surfaces could not have been lower than an elevation of $27.40 \mathrm{~m}$. Because they were just under the topsoil, the surfaces were not preserved. However, a threshold in W220 (elevation $27.71 \mathrm{~m}$ ) seems to be in situ.
} 
Stratum 2 is the earliest significant occupation phase uncovered in Area 2000. In the first half of the 5th century C.E., Units 1 and 2 were constructed, around the same time as the synagogue building in Area 3000. Units 1 and 2 are delineated by the following walls: W222 (north), W218 (east), W208 and W209 (south), and W223 (west). Rooms 5-10 were constructed in the second half of the 5 th century. The difference in elevations between the surfaces in Units 1 and 2 and Rooms 5-10 (see above) is the result of architectural alterations and the accumulation of domestic refuse around Units 1 and 2 over roughly 50 to 75 years, from ca. 400 c.E. to the later 5 th century. Rooms 5-10 are delineated by the following walls: Room 5: W225 (north), W223 (east), and W234 (south); Room 6: ${ }^{15}$ W239 (north), W230 (east), W225 (south), and W236 (west); Room 7: W215 (east), W222 (south) and W230 (west); Room 8: W240 (east), W222 (south), and W215 (west); Room 9: W218 and W240 (west); and Room 10: W231 (north) ${ }^{16}$ and W236 (east). ${ }^{17}$ This stratum ends with the abandonment and collapse of Units 1 and 2 and Rooms 7-9 by the late 6 th century C.E.

Stratum 3 dates to the 6 th century C.E. At this time, new structures were built in the western part of Area 2000, some of them comprising repairs and building onto walls from the previous stratum and thus maintaining the same wall orientation while creating a new layout. In Room 5, the upper parts of the southern and eastern walls were rebuilt (W211 above W234 and W210 above W223), and a new north wall was constructed (W219) (bonding at its eastern end with W210), slightly reducing the room's dimensions in comparison with the previous phase. Although no associated floor was found in Room 5 (due to later pitting and its proximity to topsoil), the elevation of W219 (the foundation of which overlies the floors of Stratum 2) indicates a height no lower than 27.70 $\mathrm{m}$ for the surface. The western part of the room was not excavated. Two units were constructed in place of Room 6 of the previous stratum. Room 6a is delineated by W233 (north), W230 (east), W219 (south), and W241 (west). No associated floors were found in this room. Room $6 \mathrm{~b}$ is delineated by W228 (north), W230 (east), W233 (south) and W235 (west). Although it is not clear when occupation ended in Rooms 5 and 6a, occupation continued in Rooms $6 \mathrm{~b}$ and 10 (which originally were constructed in

\footnotetext{
15 In this phase, this room incorporates a larger area. Later, it was divided into two rooms: $6 \mathrm{a}$ and $6 \mathrm{~b}$.

16 Although W238 underlies W231, no associated floors were found, as it was not reached until the end of the 2014 season. Consequently, its date and relationship to the adjacent structures is unclear.

17 The full extent of Rooms 7-9 is unclear, as several of their closing walls are unexcavated. While the floors of Stratum 2 in the northern part of Room 6 are clearly associated with W236, it is unclear why this wall is exceptionally wide and appears to disappear south of W233.
}

Stratum 2) until the 9 th-11th centuries C.E. ${ }^{18}$ The Stratum 2 and 3 occupation levels in Area 2000 yielded a rich assemblage of ceramic vessels, including imported red-slipped fine wares. A representative sample of the 5th-7th-century C.E. types is illustrated in Figure 4.

Outside the confines of Room $6 \mathrm{~b}$, narrow strips were excavated in Square SE 5/6 to the east of W230 and in the corner of Room 11 (bounded by W228 and W229) up to the balks. Beneath layers of collapse, some of which contained roof tiles and burned embers, two possible surfaces were uncovered, overlaid by compact soil with mixed Stratum 2 and 3 pottery. Early Islamic occupation is not well represented in the southern and eastern parts of Area 2000 (Rooms 1-4, 7-9), where only a few sherds of the 8th-10th centuries were recovered.

\section{Area 3000: The Modern Village of Yakuk, the Medieval Building, and the Late Roman Synagogue}

Since 2015, excavations have focused entirely on Area 3000 , where the remains of the synagogue were covered by the ruins of the modern village of Yakuk, which was abandoned in 1948. The supervisors in Area 3000 were Matthew Grey (2011-2017), Dennis Mizzi (2015-2017), and Benjamin Gordon (2014). Five strata have been distinguished in Area 3000.

Stratum 1: The Late Roman synagogue was constructed in the early 5 th century C.E., as indicated by the pottery and coins from the foundation trench of the east wall and radiocarbon dating of a charcoal sample from the bedding of the mosaic floor. We have not yet determined when or why the synagogue went out of use, although there are no signs of destruction by fire.

Stratum 2: In the 12th-13th centuries, a medieval public building reused and expanded the Late Roman synagogue. The medieval public building is dated by glazed potsherds found in subsurface fills and embedded in the thick, concrete-like makeup of the floor.

Stratum 3: After the medieval public building went out of use, it was robbed out and pitted, and scattered walls and installations were constructed over the course of the 13 th-16th centuries.

Stratum 4: In the 18th-19th centuries, this was an open area with numerous cooking installations (tabuns) associated with layers of ash and a few partition walls.

\footnotetext{
${ }^{18}$ Because of extensive robbers' trenches, the evidence for Early Islamic occupation in Room 10 is less clear than in Room 6b. The most likely candidate is a surface consisting of paving stones and packed earth that survived only in patches, having suffered from stone robbing in the 13 th- 15 th centuries.
} 


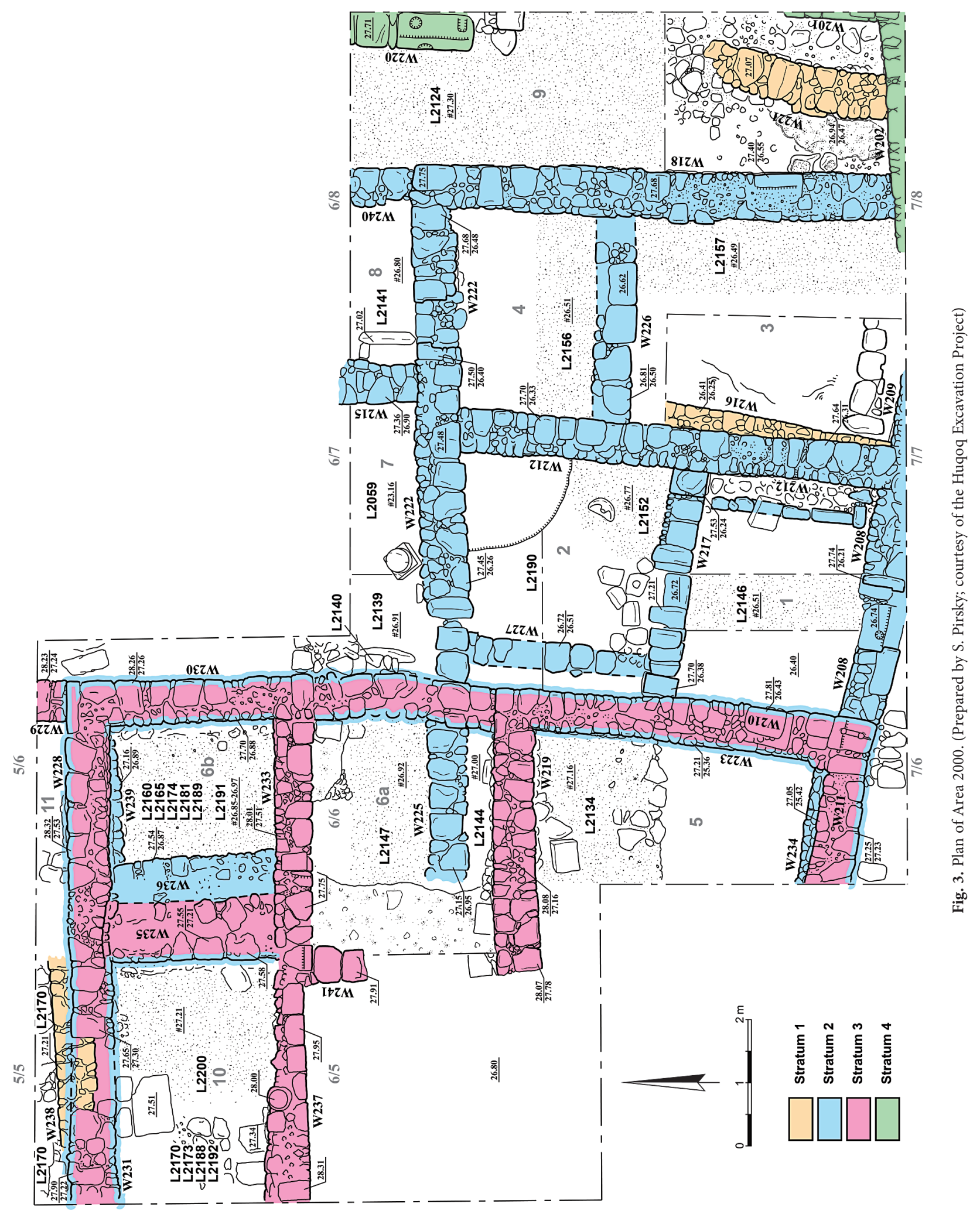



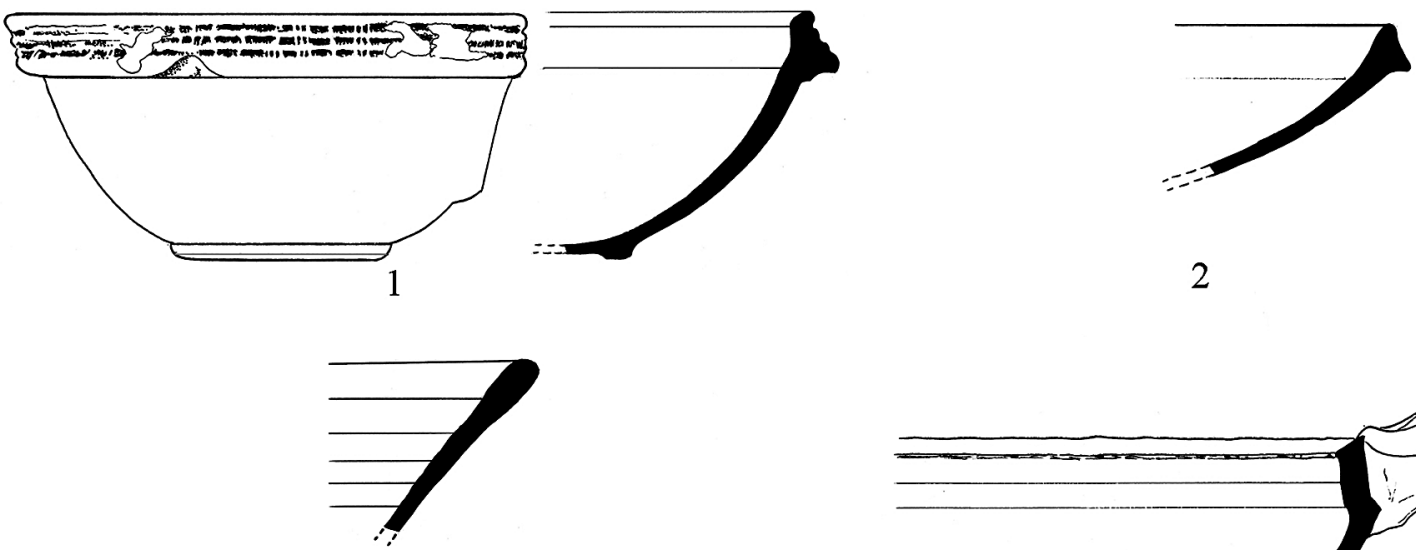

3
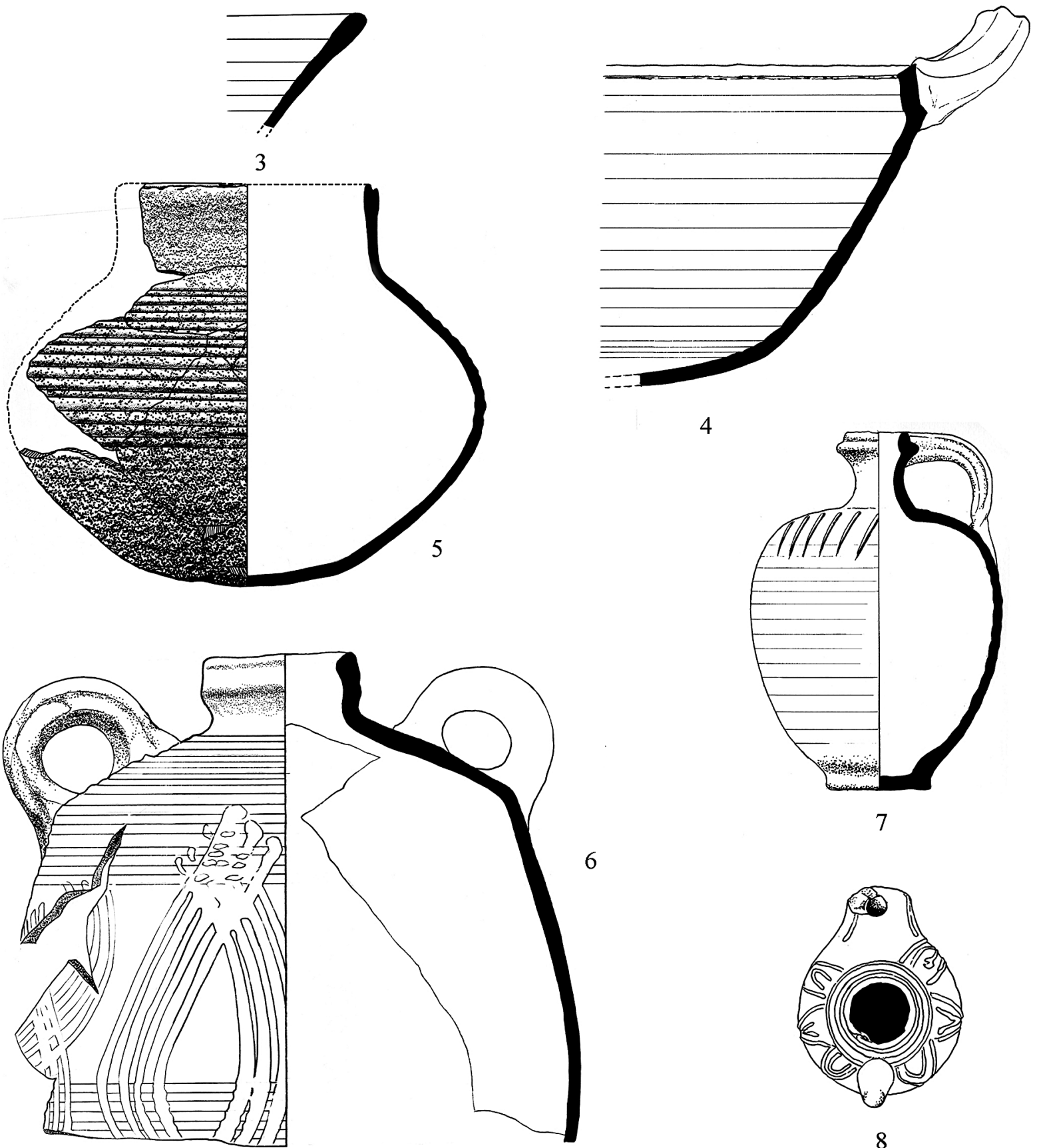

\section{4}

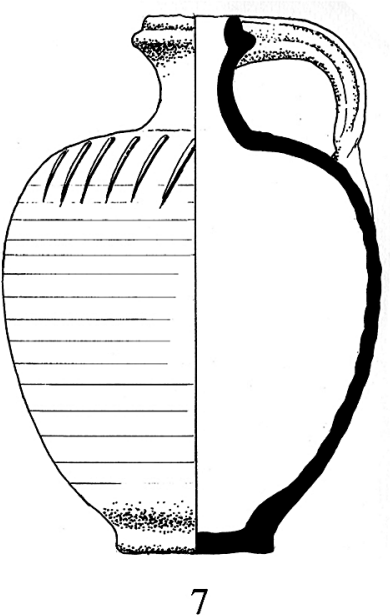

6

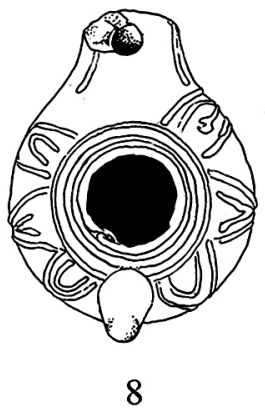

Fig. 4. Area 2000: examples of pottery from Strata 2 and 3. (Prepared by D. Schindler and R. Mohr; courtesy of the Huqoq Excavation Project) 
Stratum 5: In the late 19th century and first half of the 20th century, the area was built up with houses separated by a north-south alley.

The following discussion describes these remains beginning with the most recent stratum (5) and focusing especially on Strata 1 and 2.

\section{Stratum 5: The Late Ottoman to Modern Village of Yakuk (Late 19th Century to 1948) (Fig. 5)}

This stratum is characterized by the establishment of domestic structures along a north-south alley: two large, adjoining buildings to the west (Units 1,2), one in the southeast (Unit 3), and a third building in the northeast (Unit 4). At the southern end of Area 3000, the houses built above the earlier ash-and-tabun layer were covered by another ash-and-tabun layer, above which a large house (Unit 3), dating to the last occupation phase (pre1948), was established.

The modern village houses are constructed mostly of small basalt fieldstones, sometimes incorporating reused limestone building stones and architectural fragments from the synagogue. Each dwelling consists of a single room with one or two sets of supporting arches for the roof, which were carried on pairs of pilasters, built of hewn rectangular stones and set upon a rectangular block with a foundation of packed stones (Fig. 6). The stone arches carried wooden ceiling beams overlaid by layers of mud, plaster, and smaller pieces of wood. The rooms had plaster floors and contained built installations. ${ }^{19}$ The finds include 20th-century coins and numerous glass and metal artifacts, such as tools, wires, and even house keys, as well as modern Rashaya pottery, black Gaza ware, and imported porcelain (Fig. 7:6-10).

The most completely excavated dwelling (Unit 1) dates from the 1920s through 1948. It had at least two major occupation phases, distinguished by the raising and narrowing of a semicircular entryway accessed by a ramp from an alley to the west (Fig. 8). The north side of Unit 1 still contained installations in the recessed spaces on either side of the pilaster. On the west side of the pilaster, a two-legged mud-brick stove was found (Fig. 9) together with various objects, including perforated metal braziers, a tripod gas burner, and a green glass bottle embossed with "This bottle made in Scotland." The recessed space on the east side of the pilaster yielded the burned remains of a trunk made of wood and iron sheets, which contained a shell, a stone weight, a coin, and a wooden

${ }^{19}$ For parallels to some of these features in traditional Palestinian dwellings in the Hebron Hills, including the stone arches, ceiling and roofing materials, and mud-brick installations, see Hirschfeld 1995: $126,136-37,175-78$. diptych picture frame (Fig. 10). A complete ceramic jar lay smashed on the floor next to the trunk.

This stratum - the last in Huqoq's long history-ended with a conflagration in 1948 that burned the ceiling timbers and caused the walls and ceilings of the structures to collapse. The destruction of all the excavated houses by fire indicates that it was the result of a deliberate act. The archaeological remains suggest the villagers had time to collect their most valuable possessions before fleeing but left the rest behind. After 1948, a layer of dirt accumulated on top of the floors, and the burned-out houses were used for military exercises by the Israel Defense Forces, as evidenced by scattered shell casings. In the 1960s, the Israeli government bulldozed the remains of the ruined houses, creating an overlay of mounds of rubble.

\section{Stratum 4: The Ottoman Period (18th- 19th Centuries C.E.) (Figs. 11, 12)}

In Stratum 4, Area 3000 was an open space with cisterns on the east and south, surrounded by several built installations and numerous tabuns (Fig. 13). The tabuns, sometimes fenced off by meager walls, together with the adjacent cisterns suggest this space was used for food preparation. Massive quantities of ash from the tabuns were deposited throughout the area and accumulated above the post-medieval remains of Stratum 3. The houses of the modern village of Yakuk (Stratum 5) were established above the ash deposits.

\section{Stratum 3: The Mamluk-Early Ottoman Periods (13th-16th Centuries C.E.) (Fig. 14)}

There are signs of post-medieval activity throughout Area 3000, consisting of the robbing out of walls as well as the presence of pits and silos dug into the floor of the medieval public building (and sometimes through the mosaic floor of the Late Roman synagogue below). At this time, some of the stones in the medieval public building's north wall, west stylobate, and northern and western benches were robbed out. At the same time or perhaps slightly later, scattered and fragmentary fieldstone walls and installations were constructed, the complete plan and function of which are unknown. This activity was followed by the accumulation of a soil layer that covered the floor of the medieval public building and yielded pottery dating to the Late Mamluk or Early Ottoman period (15th-16th centuries). Modern fill found under the large threshold stones, associated with the doorway in the middle of the medieval public building's west wall, and in some pits indicates that the robbing and pitting activity continued into the 19th and 20th centuries. 


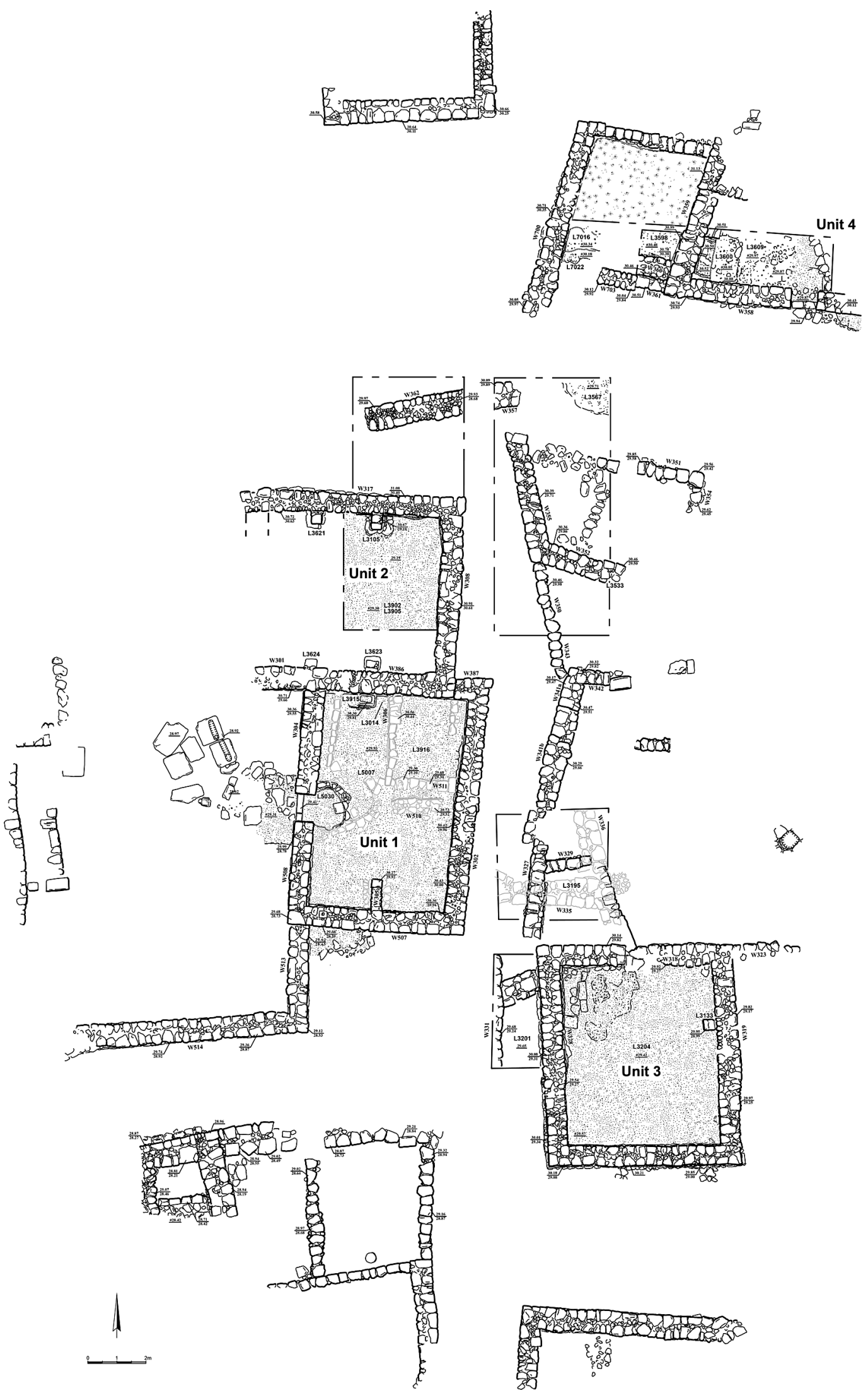

Fig. 5. Plan of Area 3000, Stratum 5. (Prepared by S. Pirsky; courtesy of the Huqoq Excavation Project) 


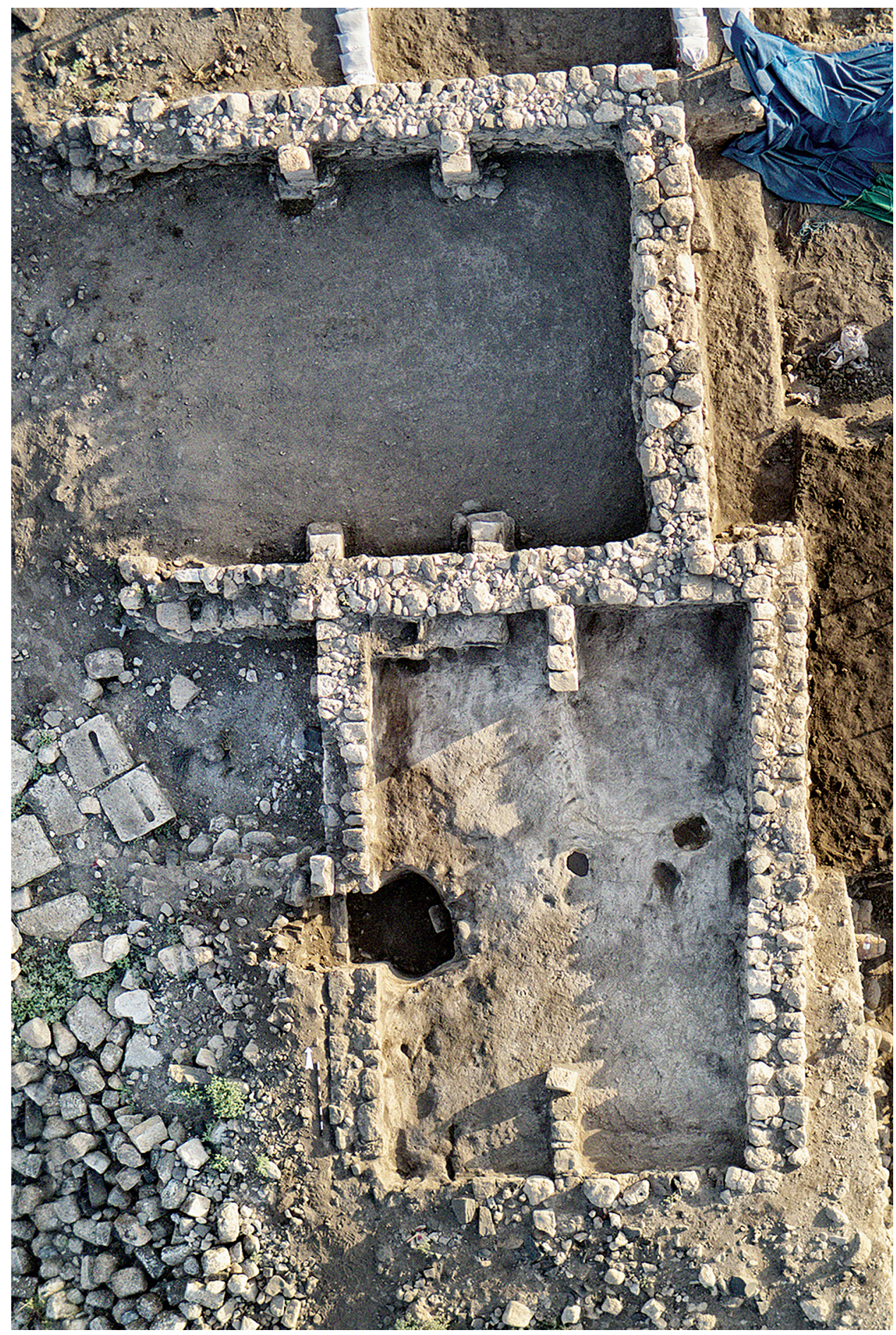

Fig. 6. Area 3000: aerial view of Units 1 and 2 (north at top). (Photo by J. Haberman; courtesy of the Huqoq Excavation Project) 

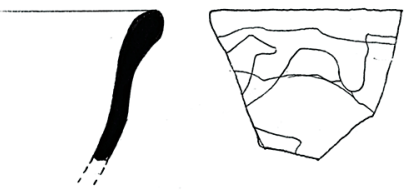

1

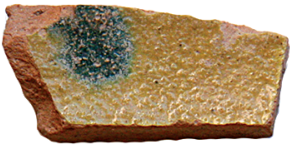

3
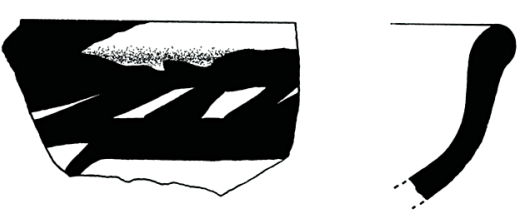

6
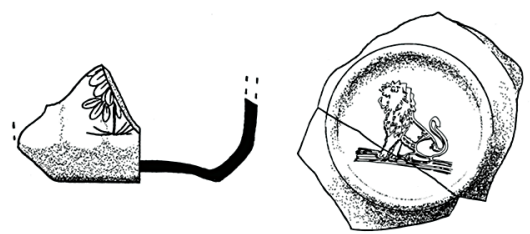

8

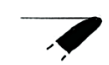

2

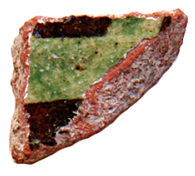

4

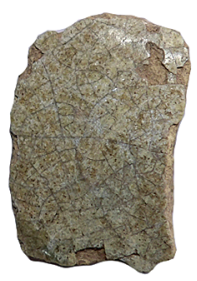

5

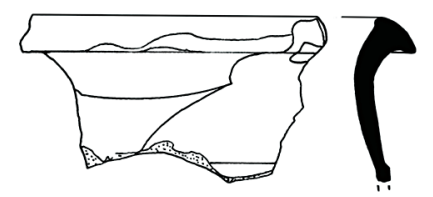

7
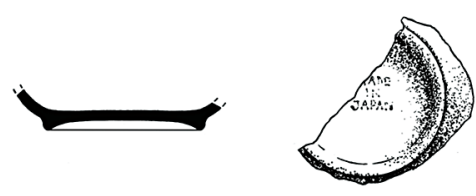

9

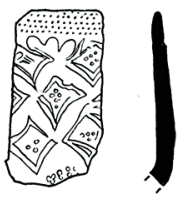

10

Fig. 7. Area 3000: examples of pottery from Stratum 2 (nos. 1-5) and Stratum 5 (nos. 6-10). (Prepared by D. Schindler and R. Mohr; courtesy of the Huqoq Excavation Project) 


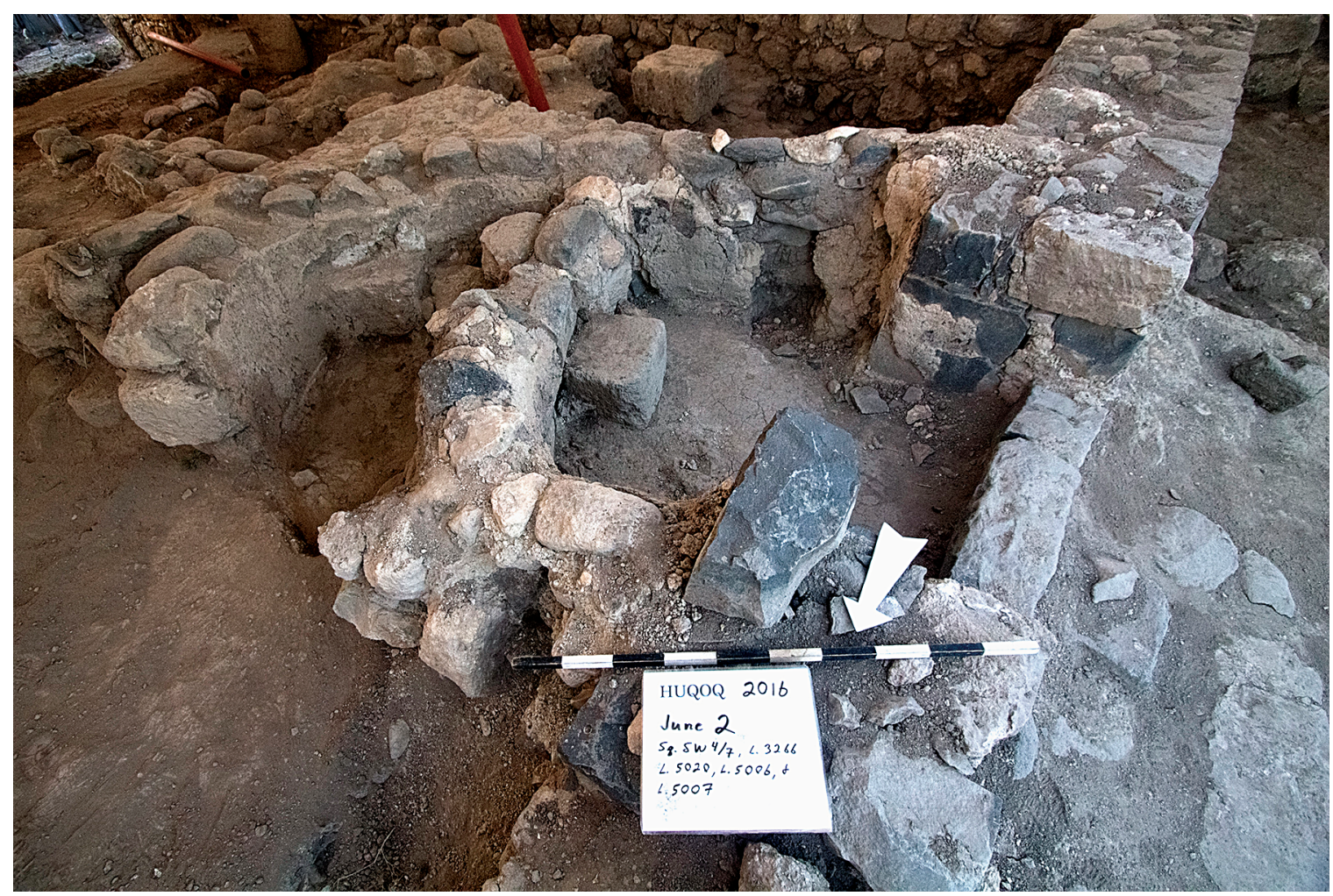

Fig. 8. Area 3000: semicircular entryway into Unit 1 showing the raising and narrowing in its later phase. (Photo by J. Haberman; courtesy of the Huqoq Excavation Project)

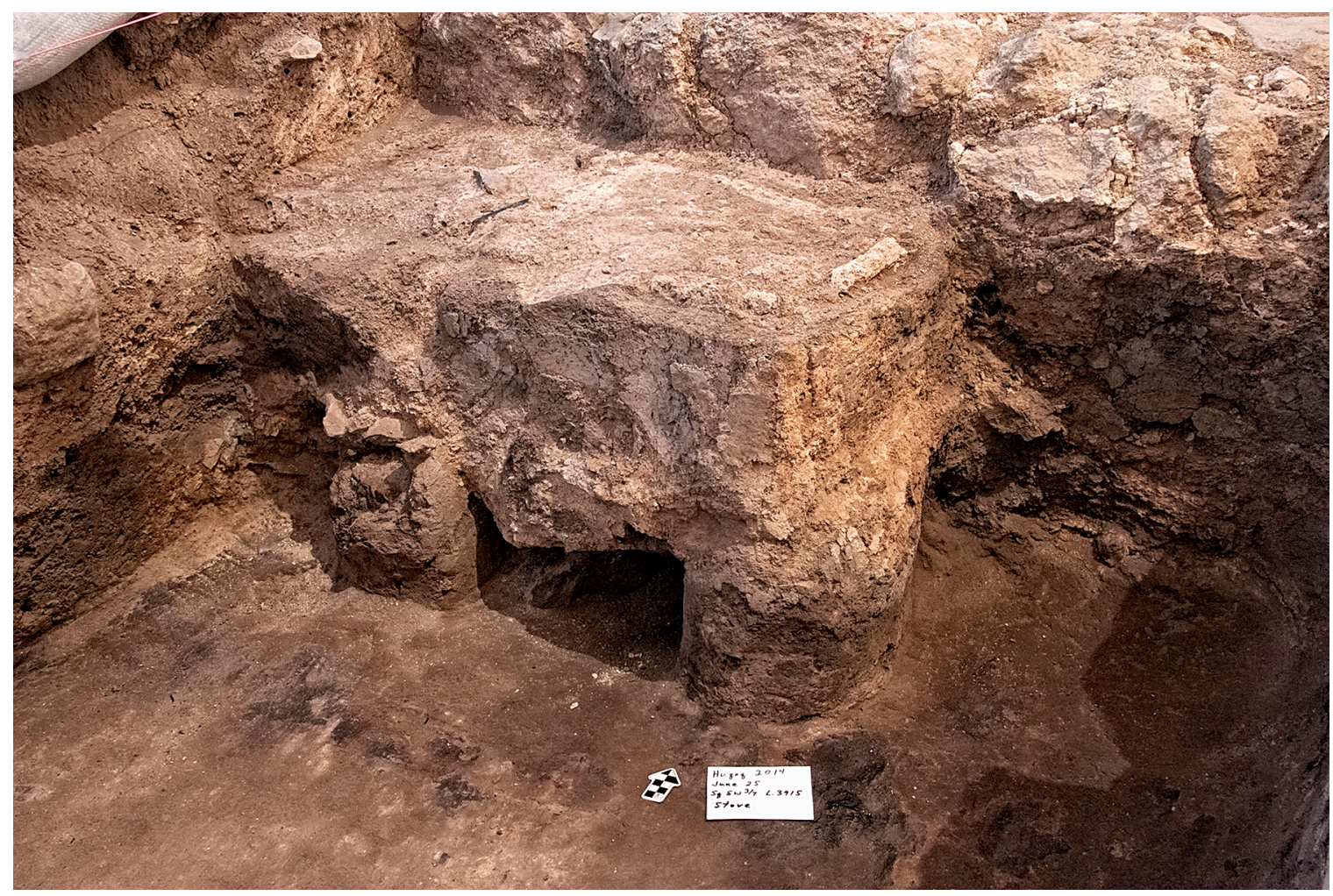

Fig. 9. Area 3000: mud-brick stove in Unit 1. (Photo by J. Haberman; courtesy of the Huqoq Excavation Project) 


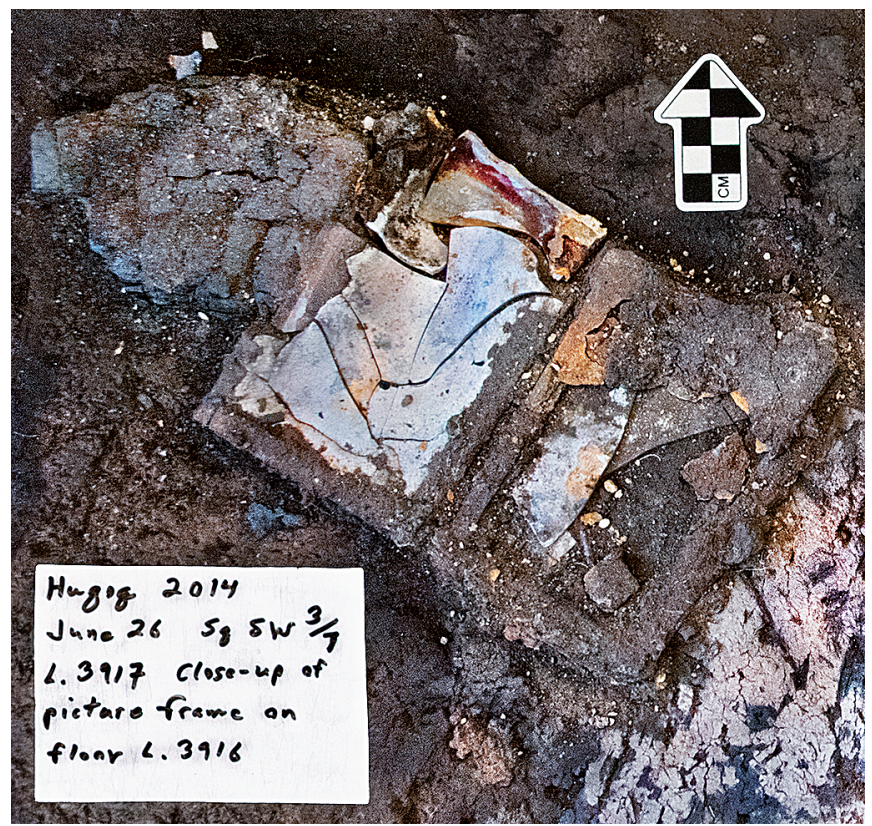

Fig. 10. Area 3000: wooden diptych picture frame from Unit 1. (Photo by J. Haberman; courtesy of the Huqoq Excavation Project)

\section{Stratum 2: The Medieval Public Building (12th-13th Centuries C.E.) (Figs. 15-18)}

In the Ayyubid, Crusader, or Mamluk period (12th13th centuries), a monumental public building was erected on the same spot as the Late Roman synagogue, reusing some of the earlier structure's architectural elements but expanding it in size (Fig. 19). Specifically, the medieval public building reused the synagogue's east wall (but extended it farther to the south) and north wall (but extended it farther to the west). Although the east and north walls are on the line of the original synagogue's walls, the incorporation of reused ashlar blocks of different sizes bonded by gray mortar indicates that parts were rebuilt in the medieval period.

Like the Late Roman synagogue that preceded it, the medieval public building is a basilica but with three doorways in the east wall and at least one in the center of the west wall. The nave is separated from the north, east, and west aisles by a stylobate, which on the north and east consists of meticulously dressed stones that supported columns on pedestals. The north and east stylobates overlie the lines of the corresponding Late Roman synagogue stylobates, and the west stylobate overlies the line of the Late Roman synagogue's (still unexcavated) west wall. The medieval public building's stylobates, columns, and pedestals appear to have originated in the Late Roman synagogue, having been dug out and lifted ca. $1 \mathrm{~m}$ to the level of the medieval floor above, as indicated by a broad, clearly defined foundation trench for the stylobate, which cut through the western edge of the mosaics in the Late Roman synagogue's east aisle and destroyed the mosaics on the east side of the synagogue's nave (Fig. 20). The stylobate's foundation trench also cut through the accumulations overlying the Late Roman synagogue's mosaic floor. The trench was filled with brown soil and was covered by leveling fills under the medieval floor.

The stones of the Late Roman synagogue's west stylobate are robbed out. One fragmentary pedestal was discovered still sitting in situ atop the east stylobate of the medieval public building, while another, found toppled on the medieval floor next to the east stylobate farther to the south, was restored to its original position. Pieces of other pedestals lie scattered in the north and east aisles. These discoveries indicate that the medieval public building measured ca. $24 \times 17.86 \mathrm{~m}$. From east to west, the interior of the building spanned ca. $16.80 \mathrm{~m}$. The nave was ca. $8.44 \mathrm{~m}$ wide, whereas the west and east aisles-respectively, $2.22 \mathrm{~m}$ and $2.66 \mathrm{~m}$ wide-were of unequal width.

Architectural pieces from the Late Roman synagogue, including plastered column drums still preserving their original painted decoration (consisting of red-andyellow vine or ivy leaves), were placed underneath and along the medieval public building's east stylobate to 


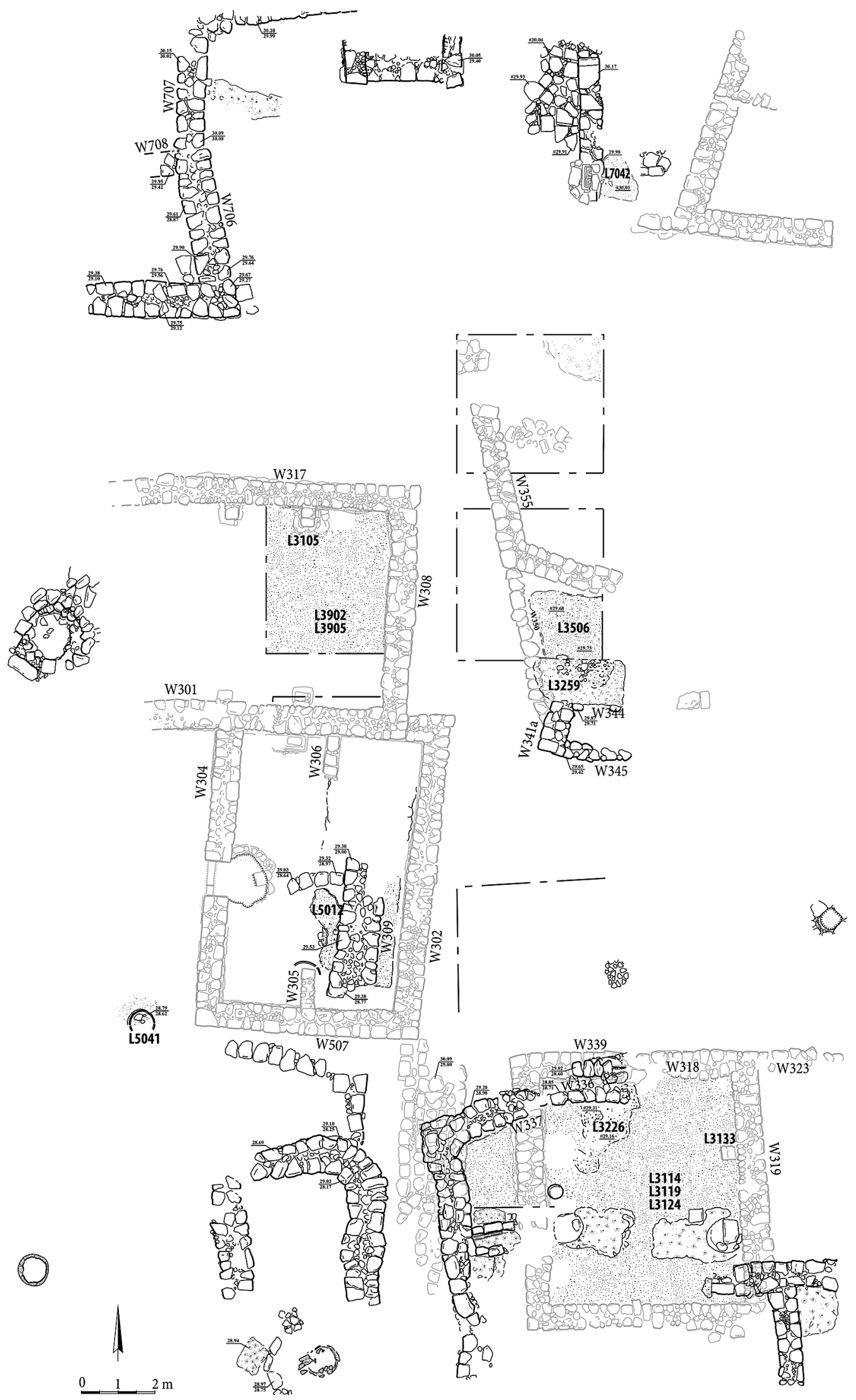

Fig. 11. Plan of Area 3000, Stratum 4 (later phase). (Prepared by S. Pirsky; courtesy of the Huqoq Excavation Project) 

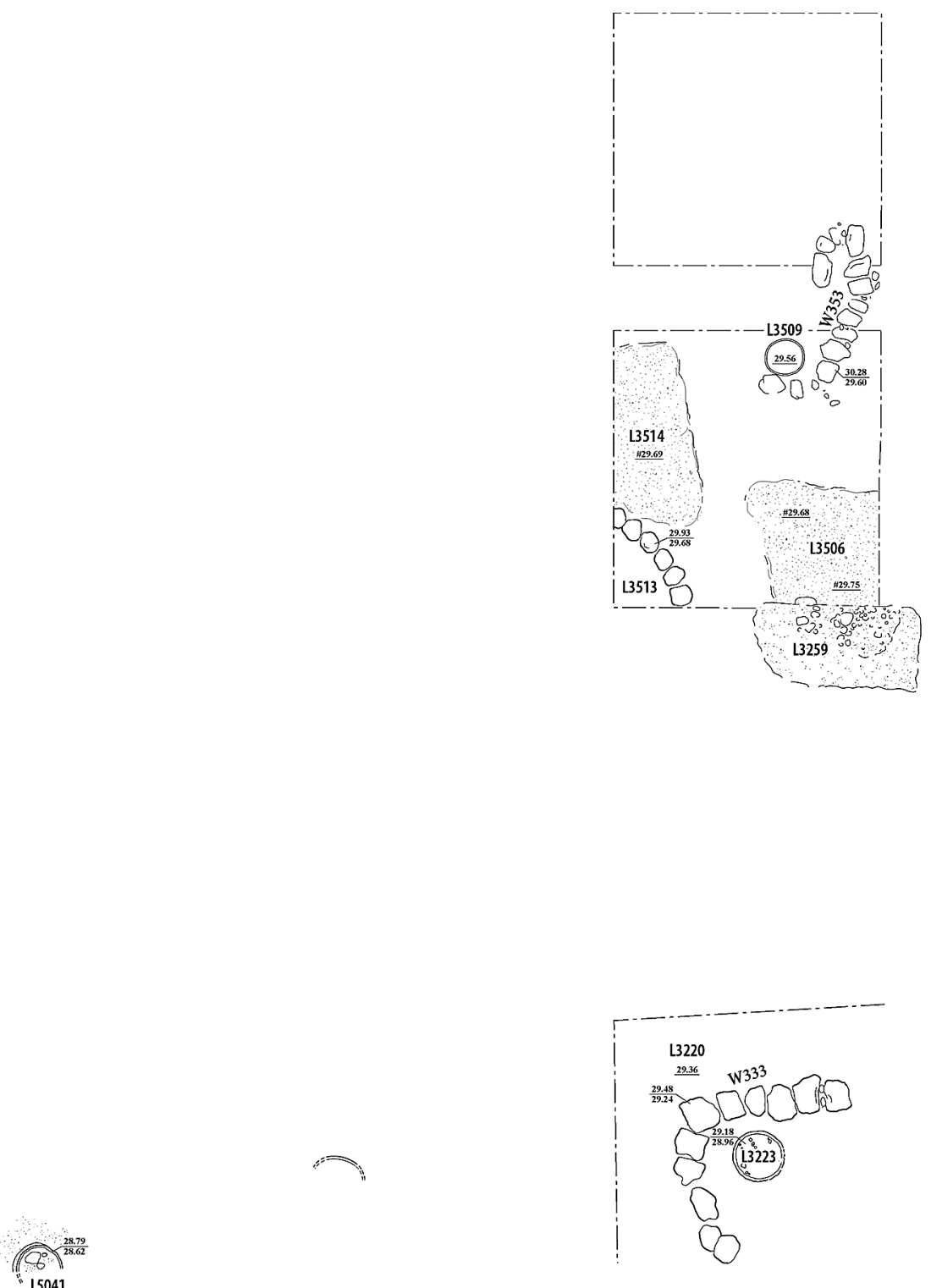

L5041
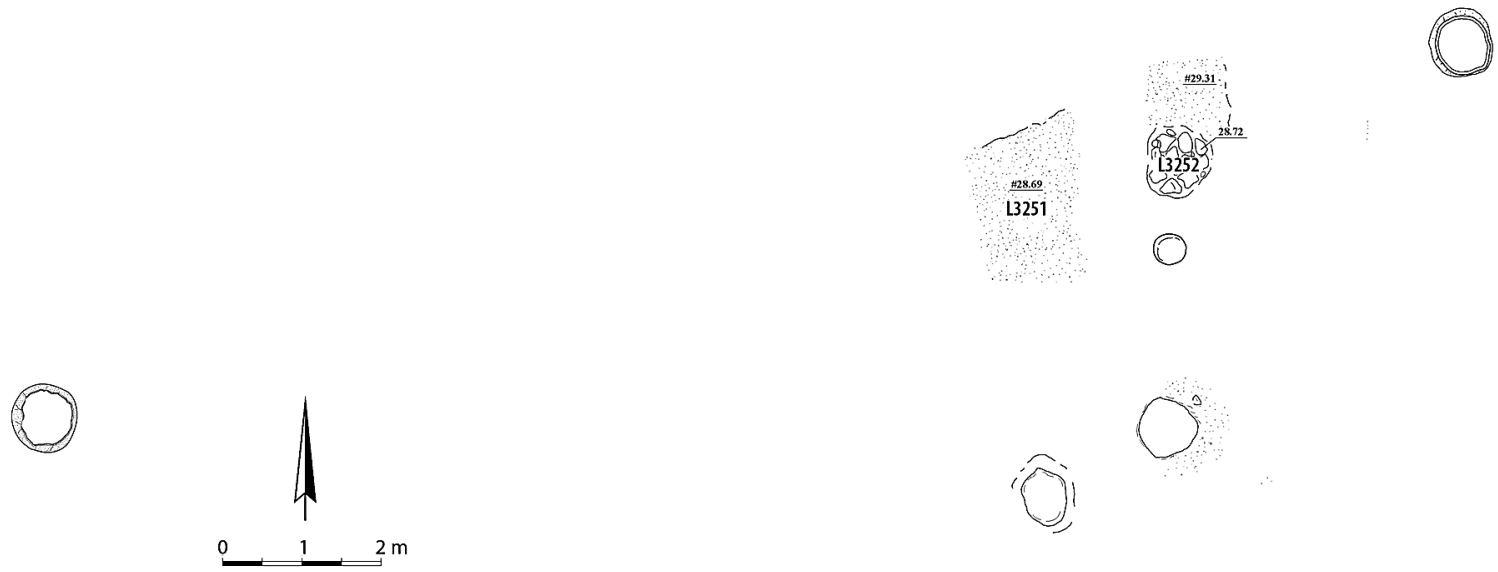

Fig. 12. Plan of Area 3000, Stratum 4 (earlier phase). (Prepared by S. Pirsky; courtesy of the Huqoq Excavation Project) 


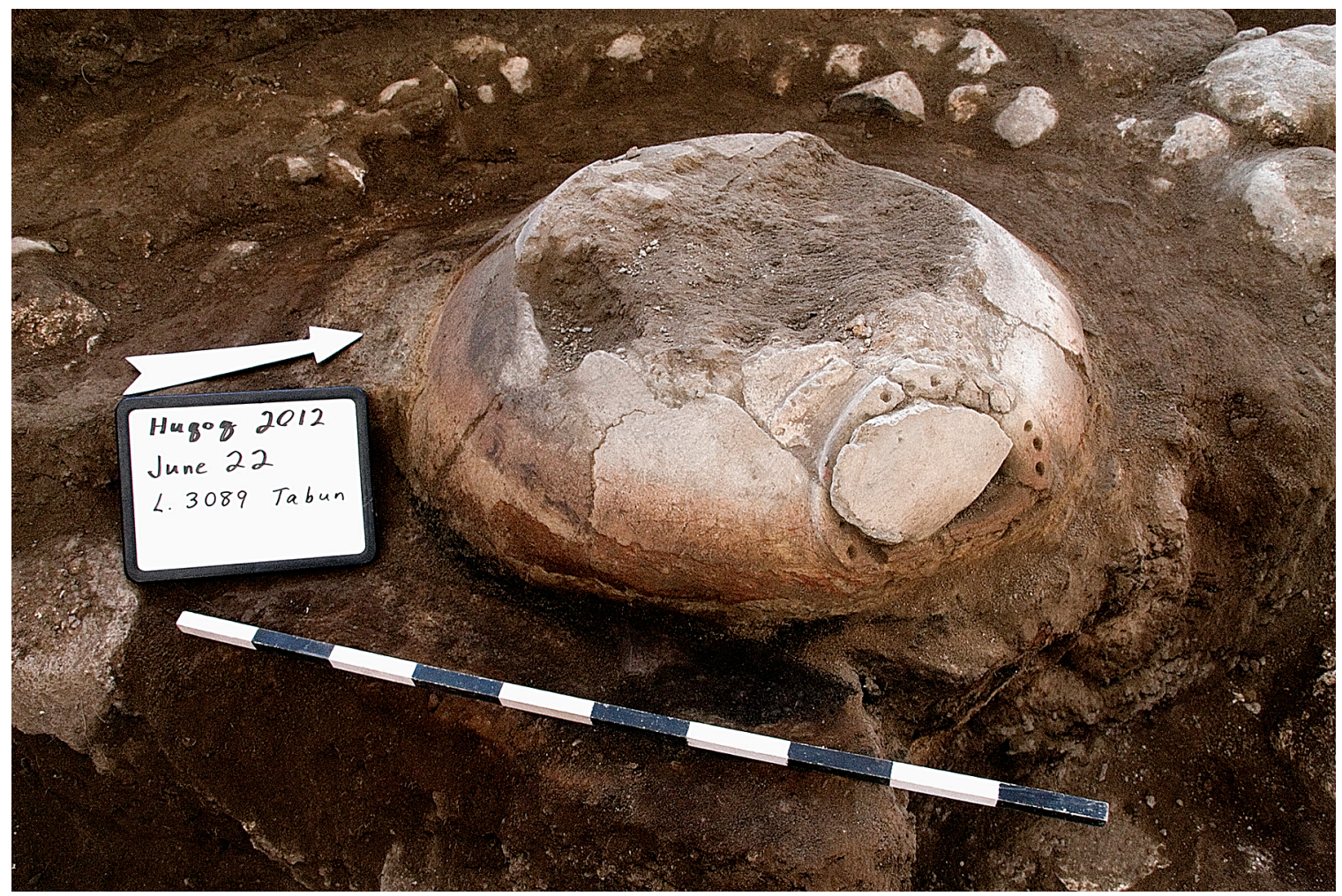

Fig. 13. Area 3000: a tabun. (Photo by J. Haberman; courtesy of the Huqoq Excavation Project)

support it and the weight of the pedestals (Figs. 21, 22). ${ }^{20}$ Additional support for the pedestals on the east and west stylobates was provided by short but massive buttress walls, also constructed with reused fragments of the Late Roman synagogue superstructure, which perhaps also provided stability in case of earthquakes. The buttresses were constructed by mortaring together the architectural elements and stone collapse under the medieval floor (Fig. 23). The building's floor is made of a bedding of large cobbles over a thick concrete-like makeup, covered with a thick layer of plaster (Fig. 24). Very small patches of white or geometric and floral mosaics are preserved, embedded in the plaster on top of the makeup in the north and east aisles (Magness et al. 2014: 343, fig. 11). A single white tessera, embedded in plaster found in situ abutting the inside of the north stylobate, indicates that the nave was paved with mosaics as well.

The medieval floor sealed layers of fill that were deposited on top of the Late Roman synagogue's mosaics. Directly overlying the synagogue's mosaics is sediment consisting of a $2 \mathrm{~cm}$ thick layer of densely packed silty clay with few anthropogenic inclusions, a unique com-

20 This cannot yet be confirmed for the medieval public building's north stylobate, as we have not excavated underneath it. position not present in the other fill layers (Fabric 1). Above is a $4 \mathrm{~cm}$ thick layer of larger limestone chips from at least two different sources, ${ }^{21}$ mixed with loose silty clay (Fabric 2). Atop this, approximately $9 \mathrm{~cm}$ above the mosaic floor, is a homogeneous layer of fine-grained limestone fragments with very few microfossils $(1.5 \mathrm{~cm}$ thick) (Fabric 3). There are indicators of water movement downward through these deposits, most strongly evidenced by laminate layers of very fine silty clay accumulated directly above the limestone chip layers (Fig. 25). These deposits were likely exposed to the elements for some time prior to the dumping of further leveling fills. There are no such indicators in the deposits directly above the mosaic surface, suggesting that this sediment (Fabric 1) was never exposed to the elements. ${ }^{22}$

The remainder of the fills above these initial deposits appears to be leveling fill of alternating loose, sandy,

${ }^{21}$ Limestone contains microfossils of foraminifera from the ancient seas from which they formed. The density and variety of these fossils within a sample can be used to differentiate between geological formations and assist with identifying the source of the material (see Wilkinson 2017).

22 Although the silty clay directly above the mosaic appears to be a deliberate deposit, Emily Hubbard cannot at this point say if it might be ceiling or roof collapse. 


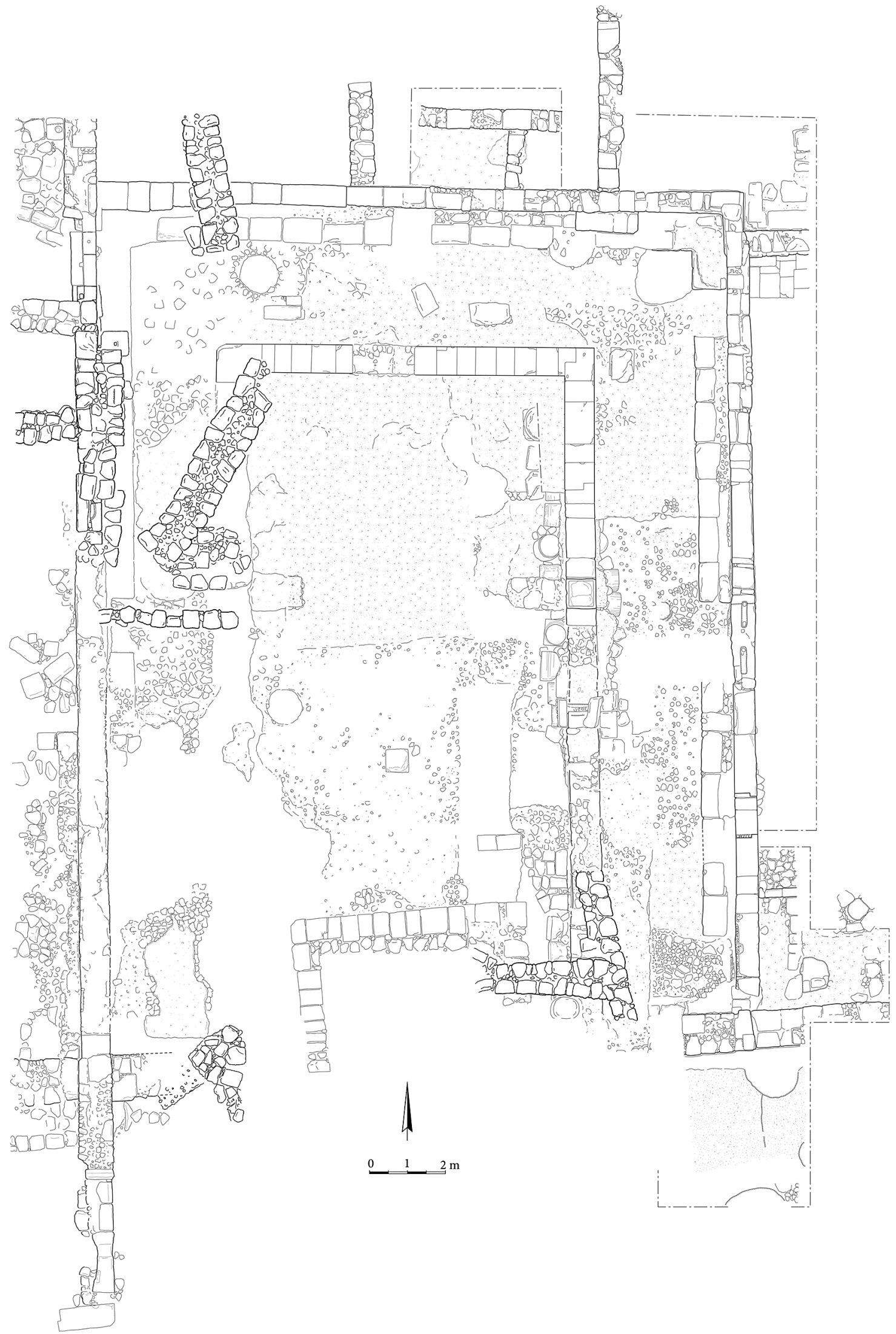

Fig. 14. Plan of Area 3000, Stratum 3. (Prepared by S. Pirsky; courtesy of the Huqoq Excavation Project) 


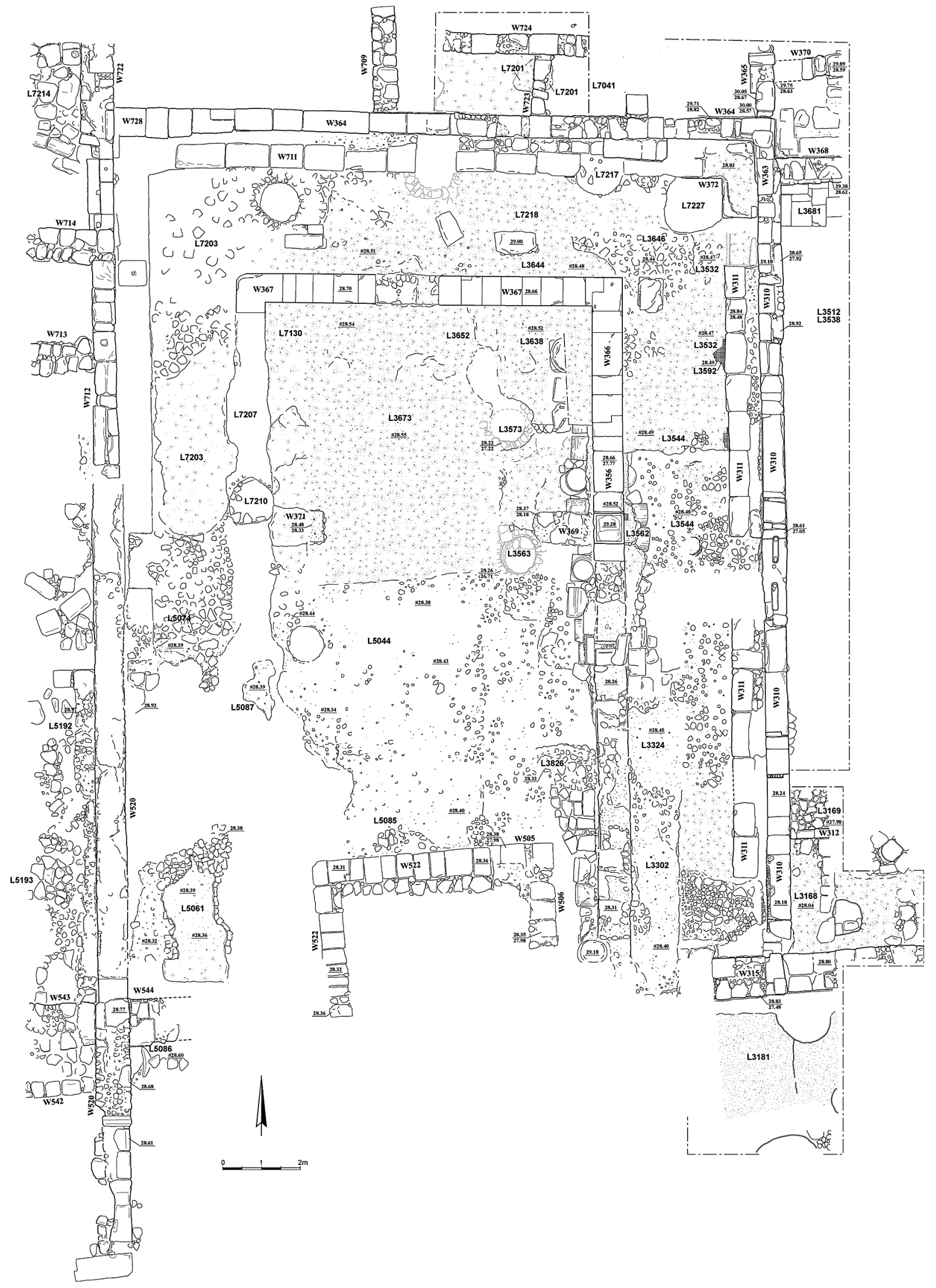

Fig. 15. Plan of Area 3000, Stratum 2 (later phase). (Prepared by S. Pirsky; courtesy of the Huqoq Excavation Project) 


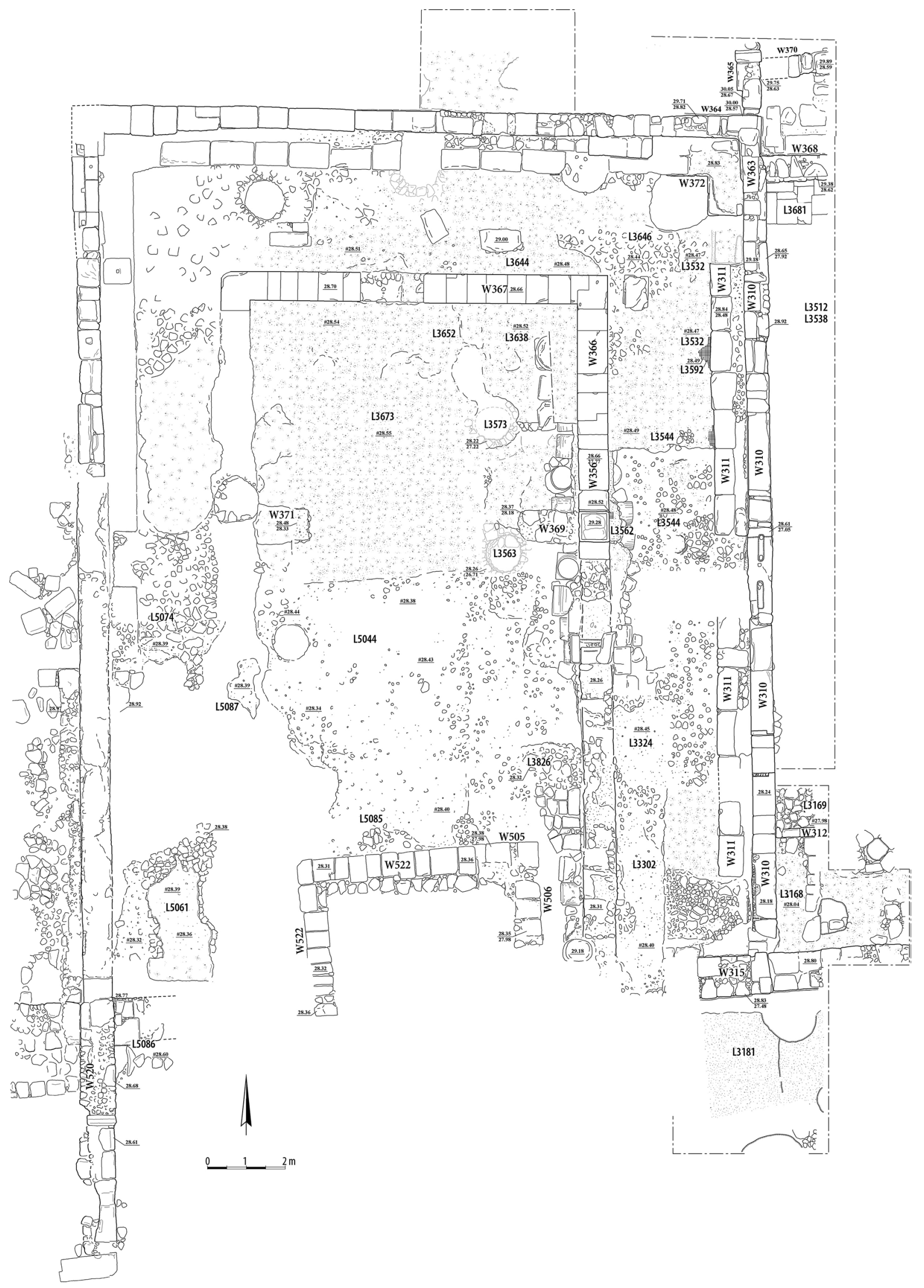

Fig. 16. Plan of Area 3000, Stratum 2. (Prepared by S. Pirsky; courtesy of the Huqoq Excavation Project) 


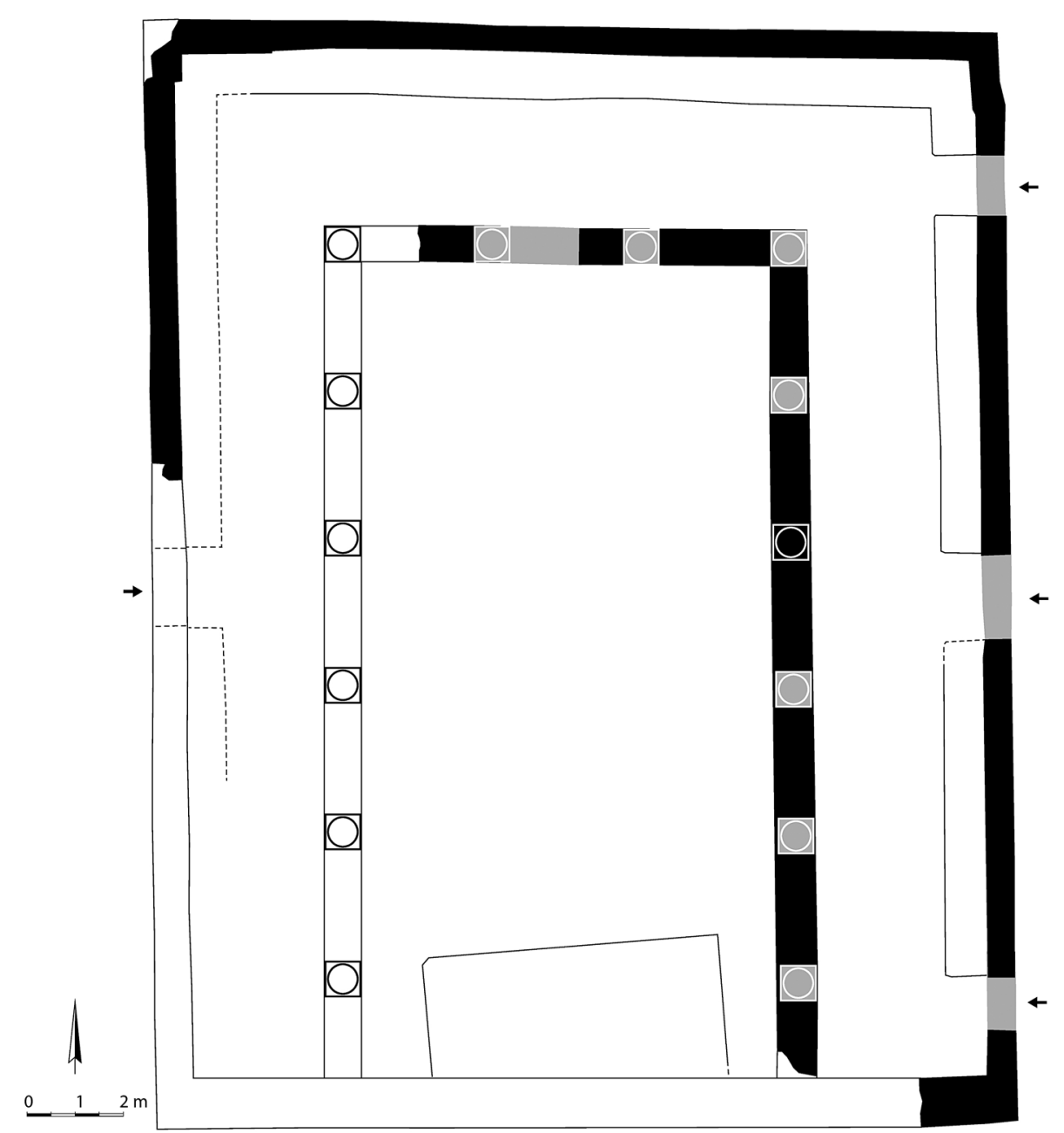

Fig. 17. Area 3000: reconstructed plan of the medieval public building. Black indicates existing excavated features, white indicates unexcavated but assumed features, and gray indicates assumed features that are not preserved in the excavated sections. (Prepared by S. Pirsky; courtesy of the Huqoq Excavation Project)

silty clay with mixed limestone chips and more densely packed silty clay with mineral aggregates (quartz, basalt) and phytoliths, charcoal, shell, and bone (Fabrics $2,4)$. The fills likely were deposited in preparation for the creation of the thick, concrete-like floor makeup of the medieval public building, which was better preserved in the northern half of the building than in the southern half (Fig. 26).

The stylobate's foundation trench cut through the accumulations overlying the Late Roman synagogue's mosaic floor. The trench was filled with brown sandy, silty clay and was covered by leveling fills under the medieval floor. The stylobate blocks were removed prior to the deposition of the leveling fills, indicating that the synagogue floor either was exposed or was covered only by the initial deposits discussed above. ${ }^{23}$ The trench cut

\footnotetext{
${ }^{23}$ Hubbard's analysis suggests the stylobate was robbed out well before the leveling fill was deposited.
}

through the mosaic floors in the synagogue's east aisle and the east side of the nave, but no remains of an earlier stylobate are visible below.

The medieval public building's dating is based on ceramic evidence. Although most of the pottery found in the fills under the building's floor is Late Roman-Byzantine, the latest types found immediately above the Late Roman synagogue's mosaic floor are Abbasid-Fatimid. Pottery embedded in the makeup of the medieval floor, in the fills immediately beneath it, and inside the makeup of the buttresses of the east stylobate includes Early Islamic types (8th-11th centuries) and glazed sherds dating up to the first half of the 12th century, as well as low-fired, handmade vessels common in the 12th century and later. ${ }^{24}$ Although not found in large quantities,

\footnotetext{
${ }^{24}$ For examples of the latest types from these loci, see Figure 7:1-5.
} 


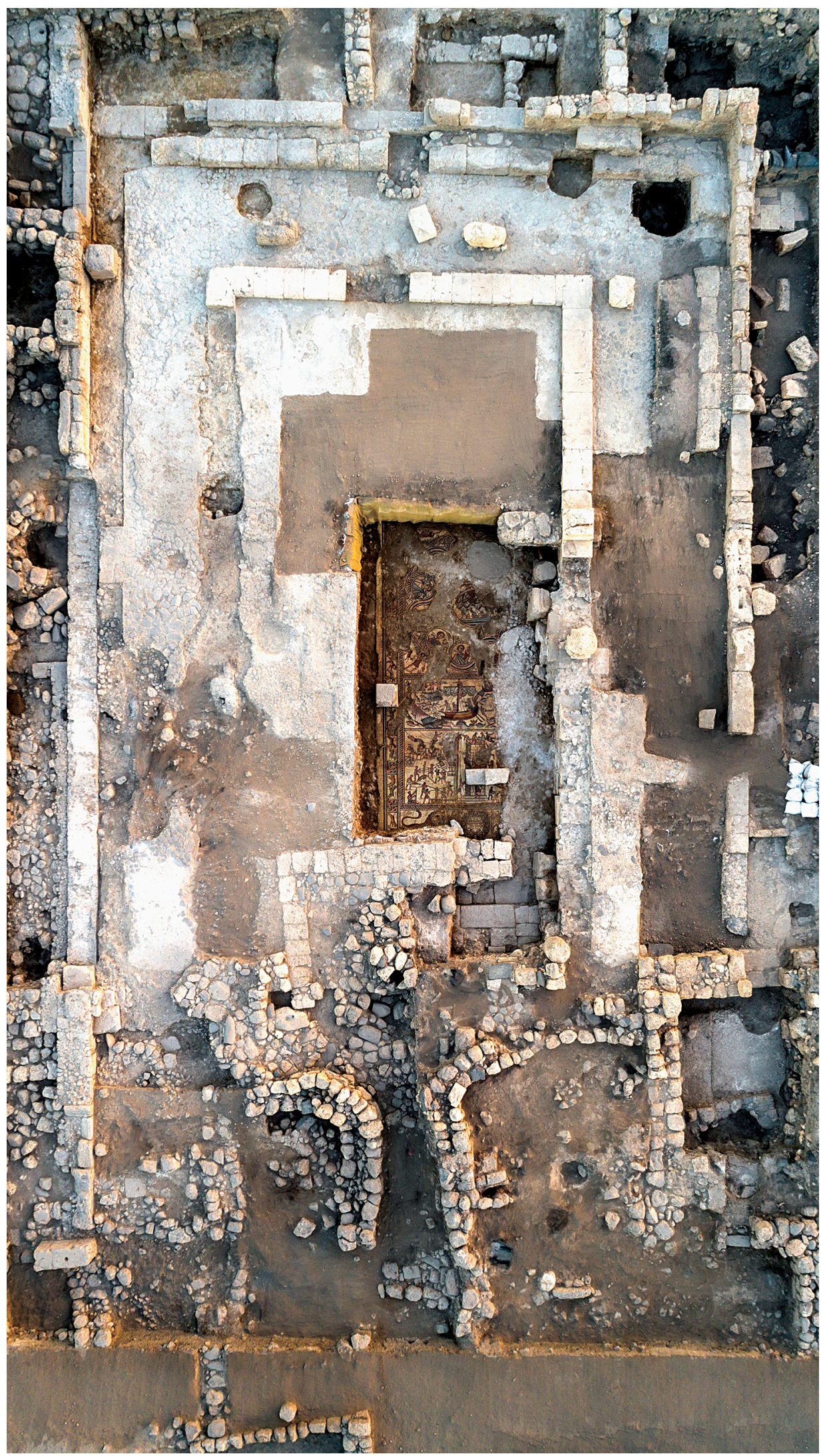

Fig. 18. Aerial view of Area 3000 showing the medieval public building at the end of the 2017 season (north at top). (Photo by Griffin Higher Photography; courtesy of the Huqoq Excavation Project) 


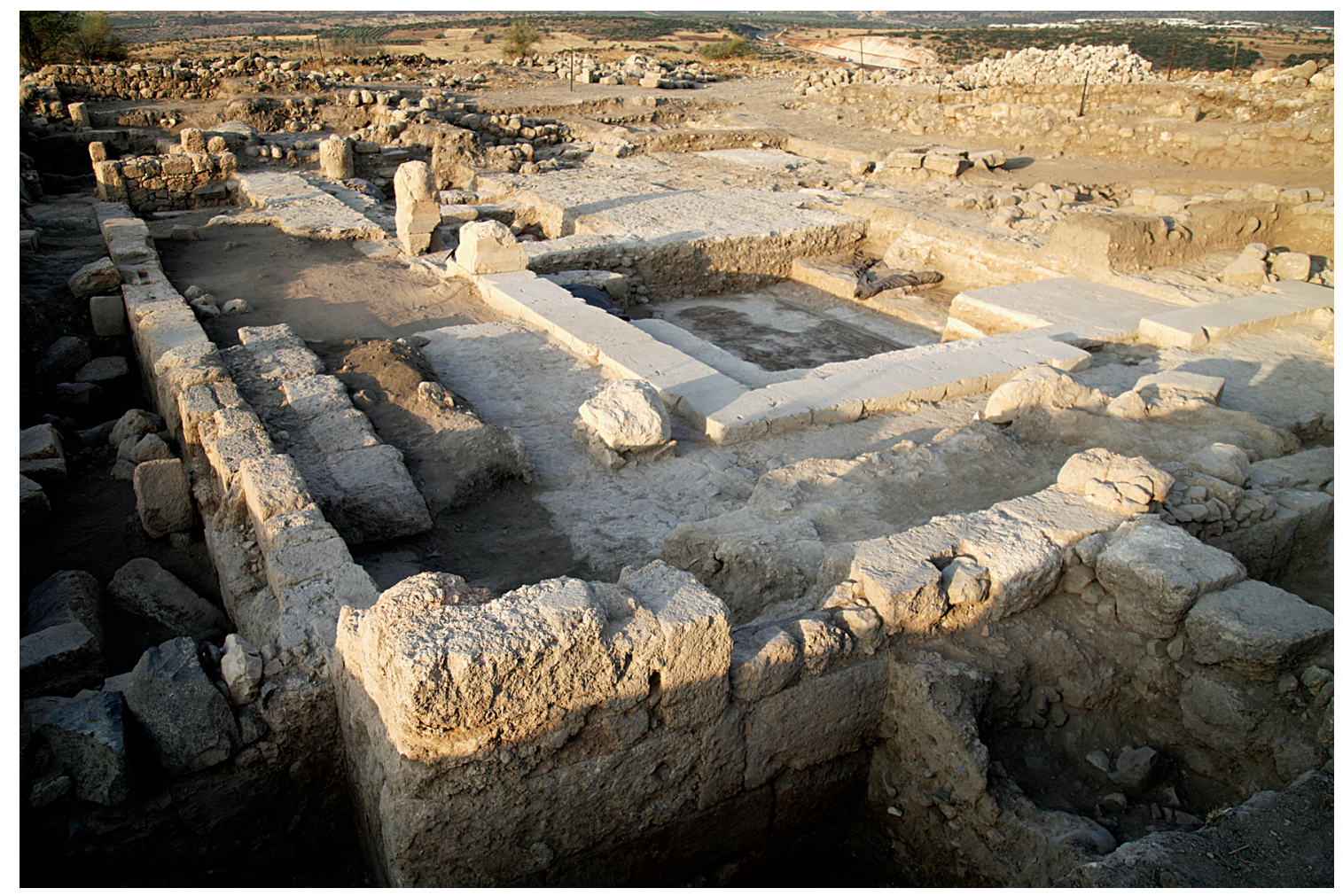

Fig. 19. Area 3000: view of the medieval public building with the northeast corner in the foreground in 2016. (Photo by J. Haberman; courtesy of the Huqoq Excavation Project)

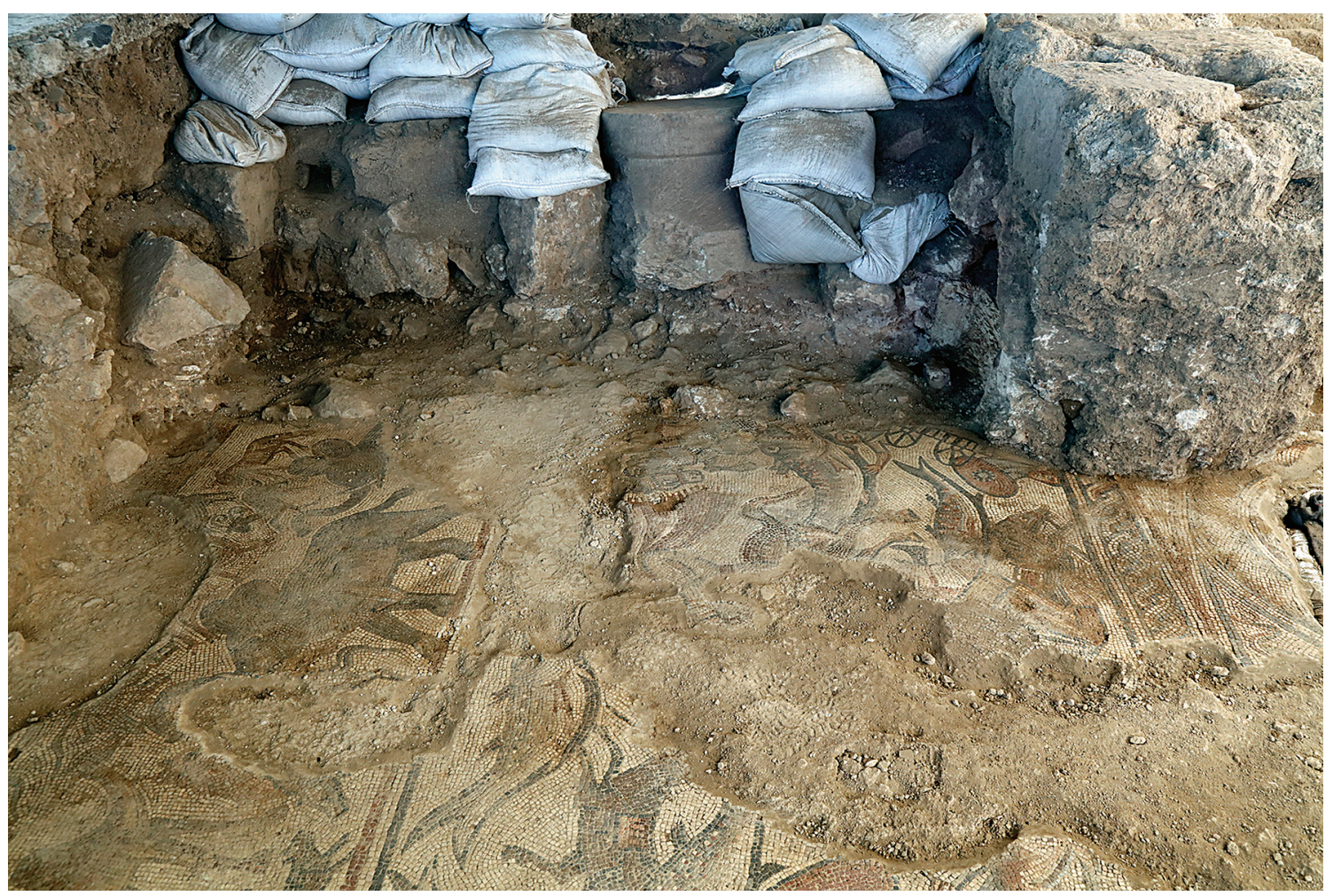

Fig. 20. Area 3000, looking east: reused architectural fragments in the foundation trench of the medieval stylobate and a buttress (on the right) cutting through the mosaic in the nave of the Late Roman synagogue. (Photo by J. Haberman; courtesy of the Huqoq Excavation Project) 


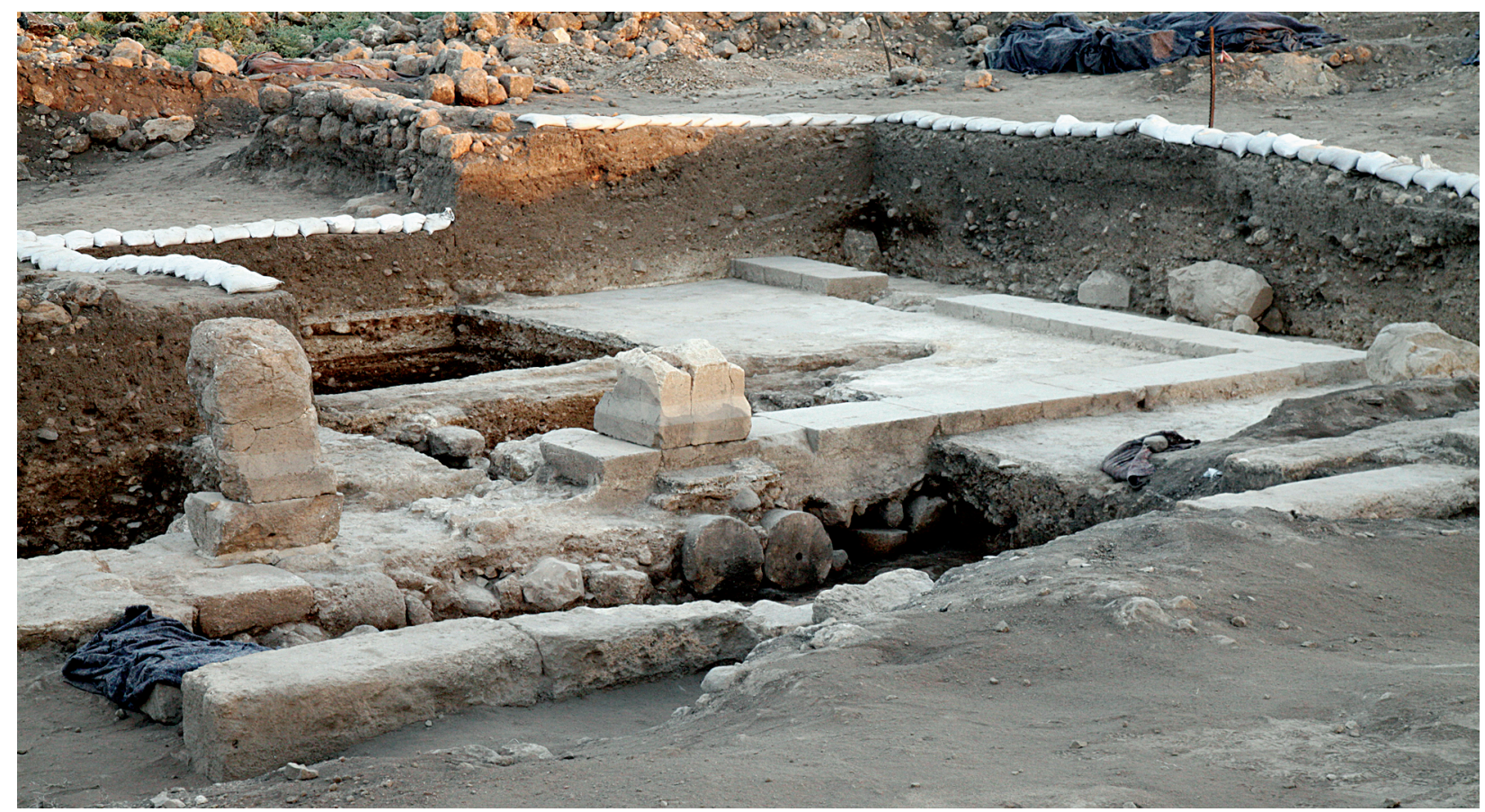

Fig. 21. Area 3000, looking northwest: reused column drums from the Late Roman synagogue under the medieval stylobate. (Photo by J. Haberman; courtesy of the Huqoq Excavation Project)

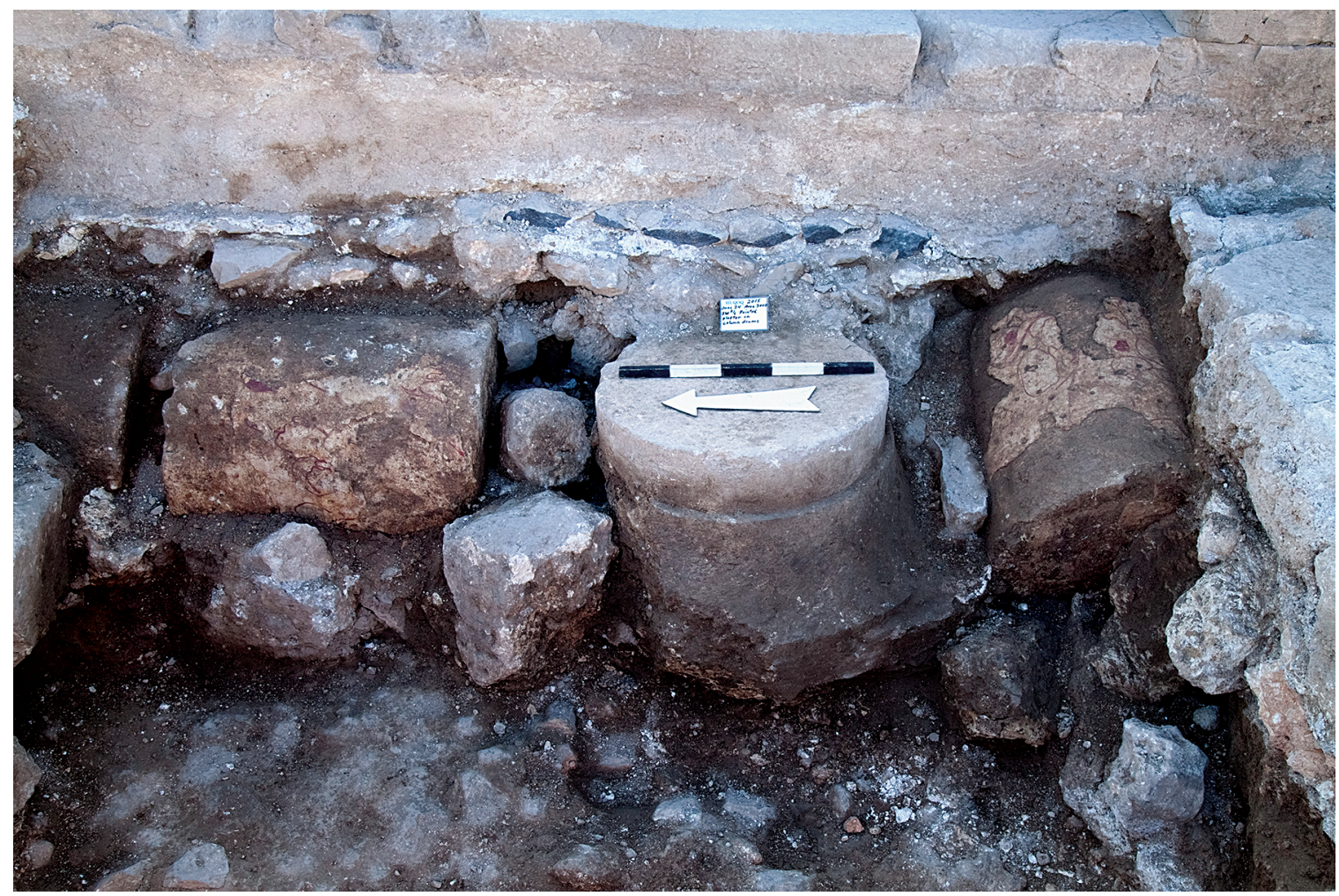

Fig. 22. Area 3000: reused architectural pieces from the Late Roman synagogue, some preserving their polychrome-painted plaster, under the medieval stylobate. (Photo by J. Haberman; courtesy of the Huqoq Excavation Project) 


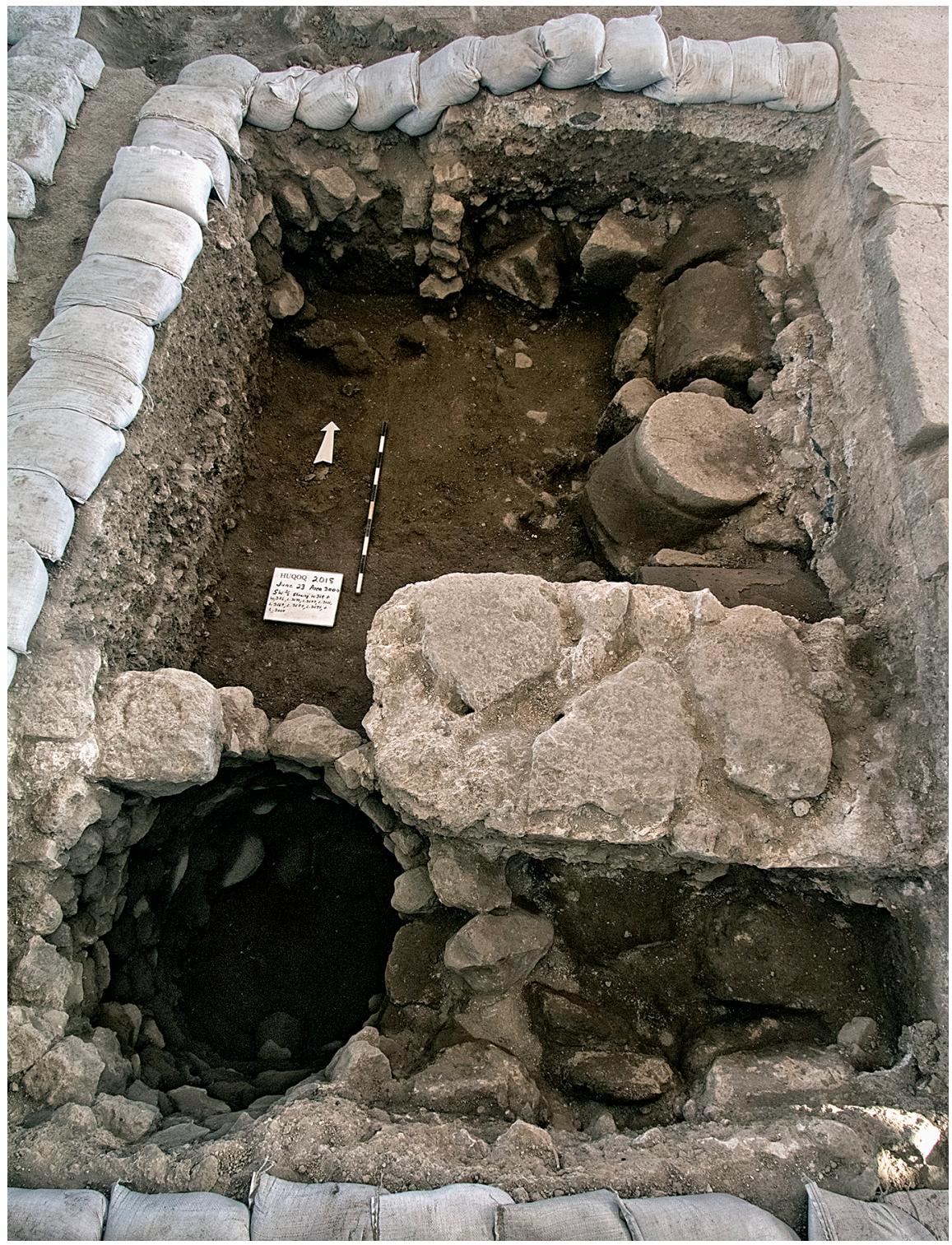

Fig. 23. Area 3000, looking north: a medieval buttress in the foreground and reused architectural pieces from the Late Roman synagogue underneath the stylobate. (Photo by J. Haberman; courtesy of the Huqoq Excavation Project)

these types appear consistently in sealed contexts in all areas across the building.

Stone benches made of reused ashlar blocks from the Late Roman synagogue lined the north, east, and west walls of the medieval public building (Magness et al. 2014: 339, fig. 10). The benches were double tiered, as indicated by the remains preserved in one section abutting the north wall. The benches suggest that the building was a synagogue rather than a church or mosque. Perhaps, this is the synagogue with a "very old floor" that Ishtori Haparchi reported seeing at Yakuk in the early 14th century (see Magness et al. 2014: 339).
Possible evidence of a second phase was found in the northwest corner of the medieval public building, where the negative outline of a bench is visible in the floor. This might indicate that the northwest corner was reconstructed, perhaps due to damage to the building while it was still in use. In the second phase, a doorway with a threshold of finely carved basalt blocks was added in the corner after the bench had been removed, and the floor was repaired. However, there is no evidence of a later floor associated with this threshold. It is therefore possible that the basalt threshold was an integral feature of the medieval building from the start, and the bench in 


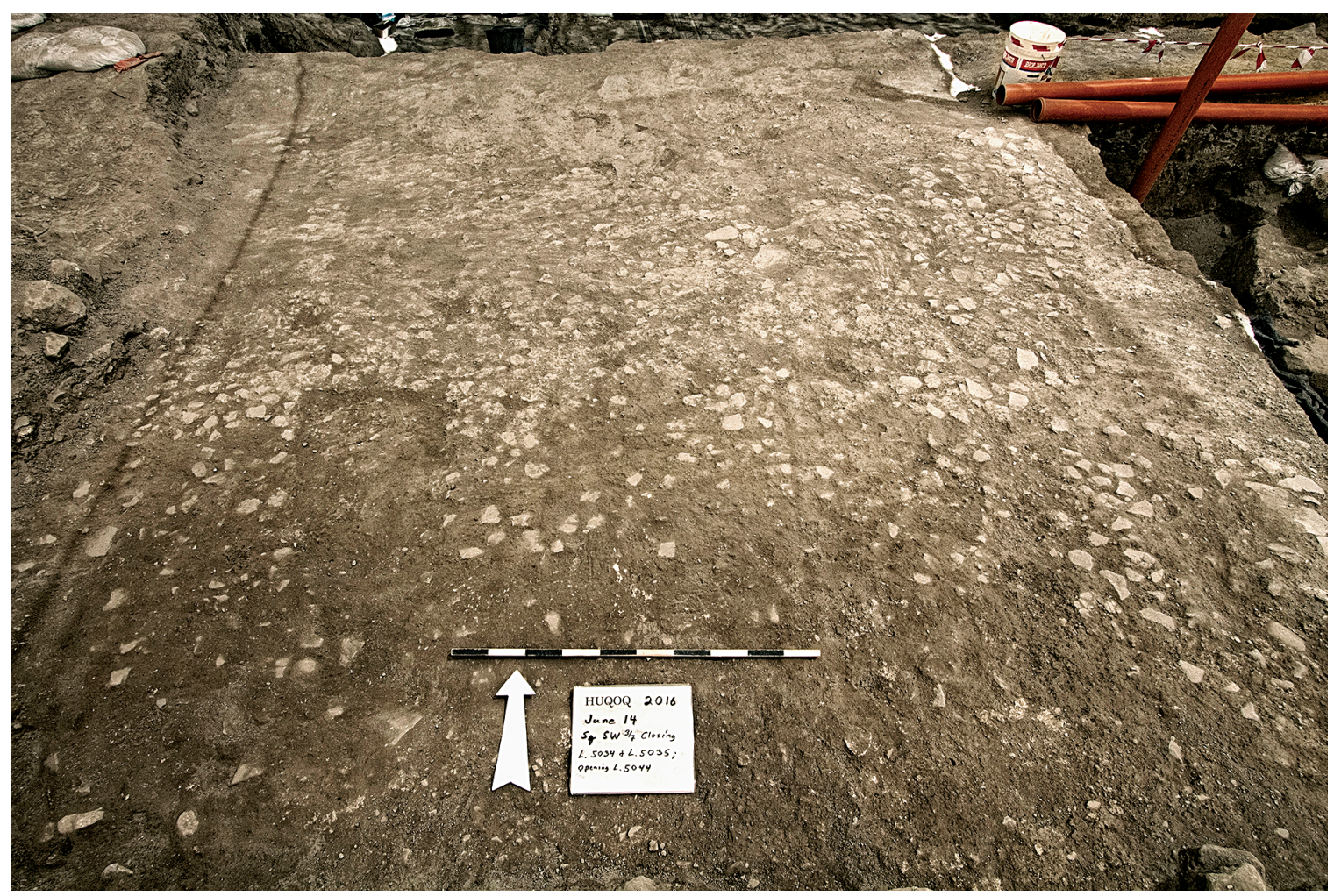

Fig. 24. Area 3000: the cobble bedding of the medieval floor. (Photo by J. Haberman; courtesy of the Huqoq Excavation Project)

this spot had a single tier. In this case, the bench could have been used as a step down into the building. Either way, the west wall of the medieval building continues northward beyond this doorway. Another doorway farther to the south in the west wall is associated with two large threshold blocks that had been robbed out in modern times and were exposed in 2011. The line of benches, although robbed out, clearly stopped on either side of this doorway, thereby indicating its location.

A ramp along the outside of the northern end of the west wall slopes up from south to north and is contemporary with the medieval public building or one of its later sub-phases, perhaps added after the ground level outside the building had risen, as attested by the continuous raising of the surface north of the building. The succession of walls there (or most of them) represents medieval sub-phases. Robbing activity farther to the south suggests that there may have been stone benches at this spot along the outside of the wall. Inside the building, evidence of numerous sub-phases, including patches of later floors and wall stubs, attests to intensive use and activity long after the initial construction. Walls belonging to structures abutting the outer side of the north wall also appear to have been added after the building's initial construction, including an extension to the north of the building's east wall.

\section{Stratum 1: The Late Roman Synagogue (Early 5th Century C.E.) (Figs. 18, 27, 28)}

The Late Roman synagogue is a basilica, with the long walls on the east and west, the main entrance(s) in the south (Jerusalem-oriented) wall, an entrance in the east wall (by the commemorative and elephant mosaic panels), and a stylobate that wrapped around the north, east, and west sides of the interior. The west stylobate is robbed out, and the floor of the nave is $0.20 \mathrm{~m}$ lower than the floor level in the aisles. The nave is ca. $5 \mathrm{~m}$ wide, and the aisles are ca. $3.60 \mathrm{~m}$ wide. Altogether, the synagogue is $20 \mathrm{~m}$ long and $15-16 \mathrm{~m}$ wide. The west stylobate of the medieval public building overlies the line of the synagogue's west wall.

Pottery and coins from the foundation trench of the east wall provide a terminus post quem in the early 5 th century for the synagogue's construction (Magness et al. 2014: 341-42). At the bottom of the foundations, the east wall was floating, with no signs of an earlier wall 


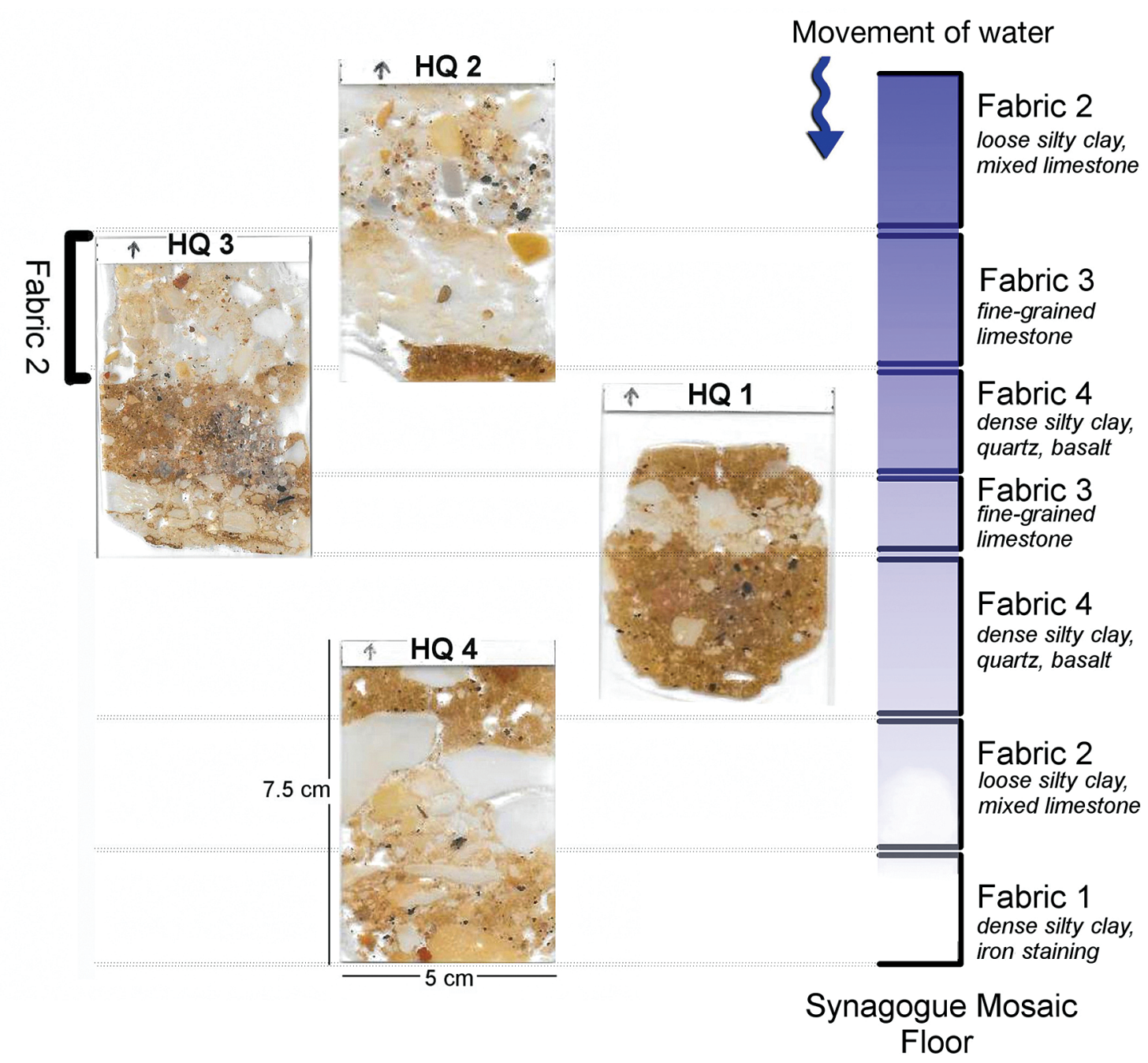

Fig. 25. Chart of the deposits above the Late Roman mosaic floor. (Prepared by E. Hubbard; courtesy of the Huqoq Excavation Project)

underneath. In 2014, a sounding was made under the plaster bedding of the mosaic floor following the removal of the panel depicting Samson carrying the gate of Gaza, located at the southern end of the east aisle. The sounding revealed that the mosaic was laid over a layer of cobblestones mixed with crushed pottery and plaster; the plaster continued below the cobblestones. Radiocarbon dating of a charcoal sample from the plaster yielded a terminus post quem of 335-410 C.E. (see Appendix C below). The latest pottery from the bedding ranges in date from the 2 nd century to the mid- 4 th century c.E. Below the bedding were layers of earthen fill without any evidence of an earlier floor. The latest pottery from these fills is the rim of a Kefar Hananya Form 1E bowl, which has a range from the mid-3rd to 5 th centuries C.E. (see
Adan-Bayewitz 1993: 103-9; Magness 2012; and Magness and Schindler 2015: 194).

In 2016 , a $0.80 \times 0.70 \mathrm{~m}$ sounding was made at the northern end of the nave (north of the Noah's Ark panel), in a spot where mosaics were not preserved but the bedding was intact. The bedding consisted of a $5 \mathrm{~cm}$ thick layer of concretized gray ash, mixed with small pebbles and set on top of a layer of cobbles. In the bedding was the rim of a Kefar Hananya Form 4D cooking pot, dated from ca. 300 C.E. to the early 5th century (see AdanBayewitz 1993: 130-32). Below the cobbles was a thick layer of fill containing only Hellenistic pottery and the rim of an Early Roman conical grooved glass bowl, which presumably were imported with dumps associated with earlier periods of occupation at Huqoq. 


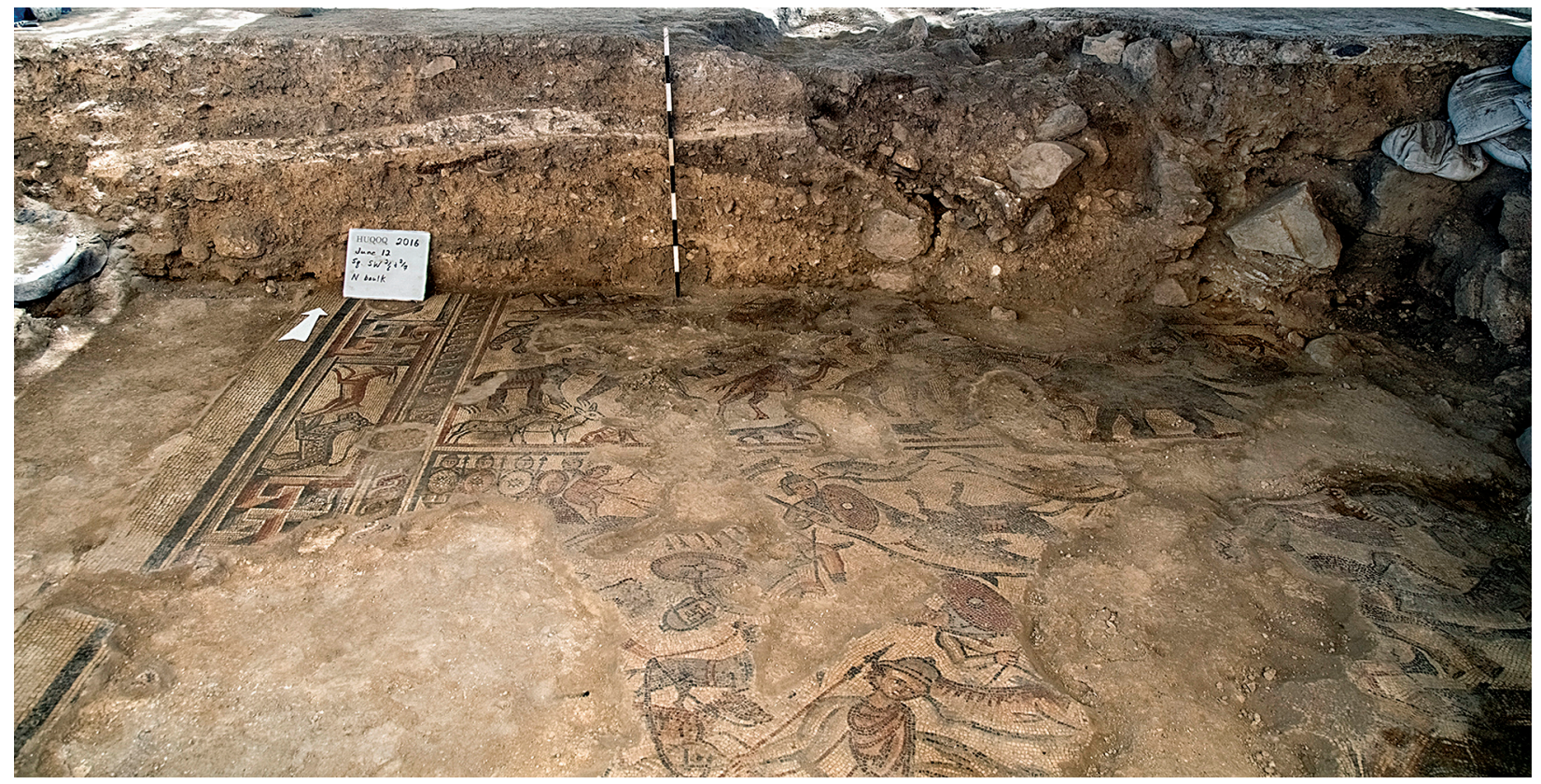

Fig. 26. Area 3000, looking north in the synagogue nave: section showing the deposits above the Late Roman mosaic up to the medieval floor (at the top of the meter stick), cut by a later pit on the right and the robber's trench of the synagogue's west stylobate on the left. (Photo by J. Haberman; courtesy of the Huqoq Excavation Project)

It is unclear when or why the synagogue went out of use. The mosaics might have been damaged by the collapse of the superstructure-perhaps caused by an earthquake but apparently only after the building's abandonment. The collapse overlies a layer of accumulation covering the mosaic floor. It appears that at least some of the fallen architectural pieces were later removed, most likely when the building was repurposed in the medieval period. At that time, layers of leveling fill were dumped over the mosaics and collapse to support the new floor $1 \mathrm{~m}$ above. However, if the team is correct that the Late Roman synagogue's stylobate and pedestals were lifted in the medieval public building, the source of the architectural pieces used to extend the later stylobates to the south and west is not known. Furthermore, the width of the robber's trench of the synagogue's west stylobate $(0.74 \mathrm{~m})$ is narrower than the stylobates of the medieval public building $(0.73-0.75 \mathrm{~m}$ on the north and $0.77 \mathrm{~m}$ on the east). ${ }^{25}$ One stone block (only the east face of which was exposed) is still preserved in the synagogue's west stylobate, abutted by a patch of mosaic floor.

${ }^{25}$ The team cannot yet account for the discrepancy between the different widths of the stylobates in the medieval public building and the synagogue. It is possible the synagogue stylobates were of different widths on the different sides, or the medieval building's stylobates did not originate in the synagogue. Hopefully, future excavation of the synagogue's north and west stylobates will clarify this issue.
As mentioned above, numerous architectural pieces from the Late Roman synagogue, including column drums still covered with colorful painted plaster, were incorporated in the buttresses and under and along the stylobate of the medieval public building (Figs. 22, 29). Large quantities of painted plaster fragments from the walls and columns as well as molded plaster pieces have also been recovered from the fills under the floor of the medieval public building and from the foundation trench of its east stylobate. The molded plaster pieces are formed from a coarse matrix, and most have a uniform off-white color. They include fragments of volutes and flutes that are similar in appearance and scale to the ornamentation of the fragmentary column capitals from the fills over the south end of the synagogue nave.

The fragments of painted wall and column plaster feature red, yellow, and white pigments. The majority of these fragments measure between 1 and $5 \mathrm{~cm}$, although the largest, preserved on column drums in situ, measure up to $0.3 \mathrm{~m}$ at the maximum preserved length. Most of the fragments are ca. $1.5 \mathrm{~cm}$ thick and have at least two discrete layers of plaster. There were at least two phases of decoration. In several fragments that separated during cleaning, a "mirror" image of the previous painted design was absorbed into the second layer of plaster while it was still wet. Pick marks (measuring ca. $1 \mathrm{~cm}$ in diameter) made by a tool to roughen the surface of the old plaster 


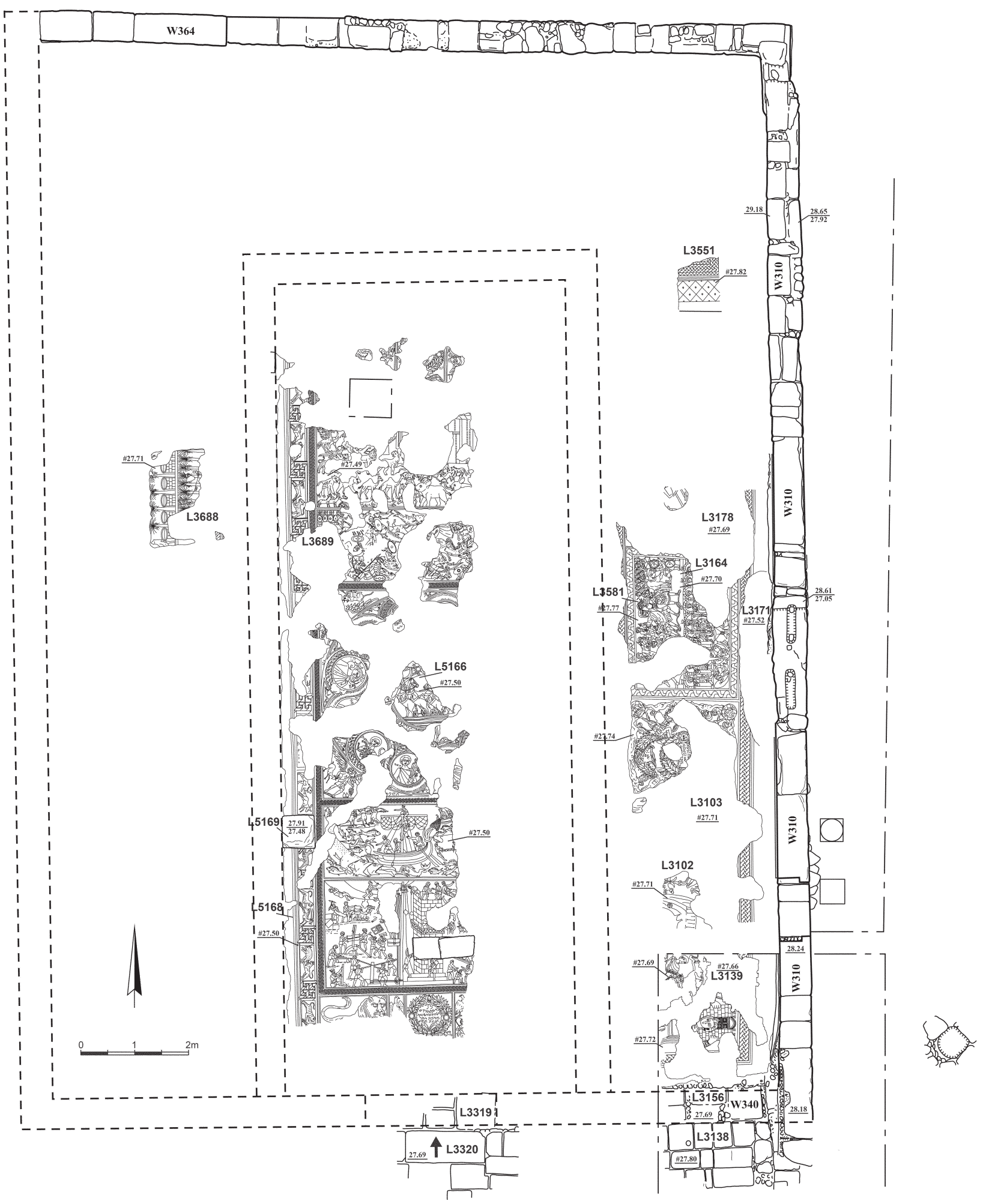

Fig. 27. Plan of Area 3000, Stratum 1 (Late Roman synagogue). (Prepared by S. Pirsky; courtesy of the Huqoq Excavation Project) 


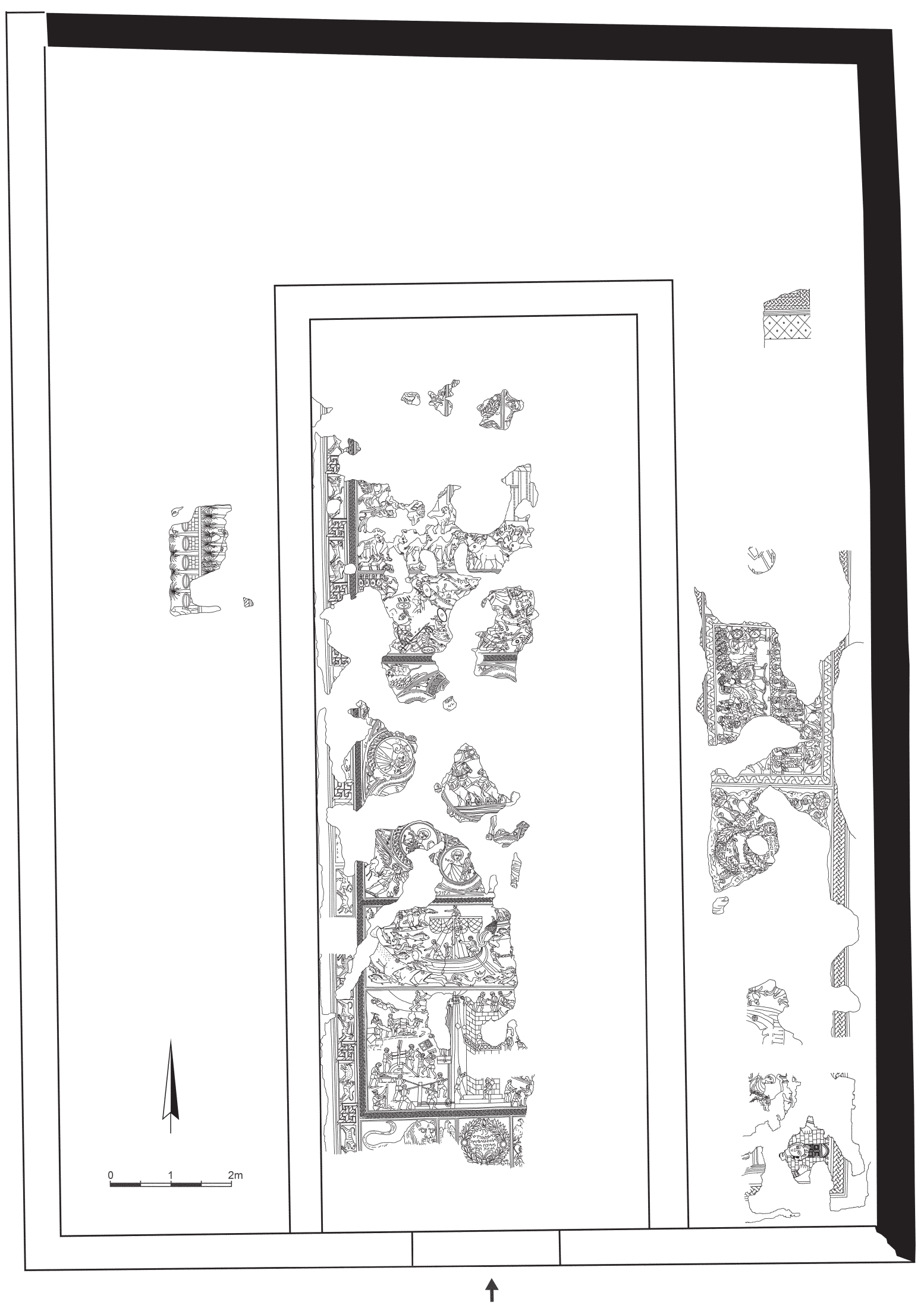

Fig. 28. Area 3000: reconstructed plan of Late Roman synagogue. (Prepared by S. Pirsky; courtesy of the Huqoq Excavation Project)

This journal was published by the American Schools of Oriental Research and is available on JSTOR at www.jstor.org/journal/bullamerschoorie. You may receive the journal through an ASOR membership or subscription. See www.asor.org/membership/individual-memberships for more information 


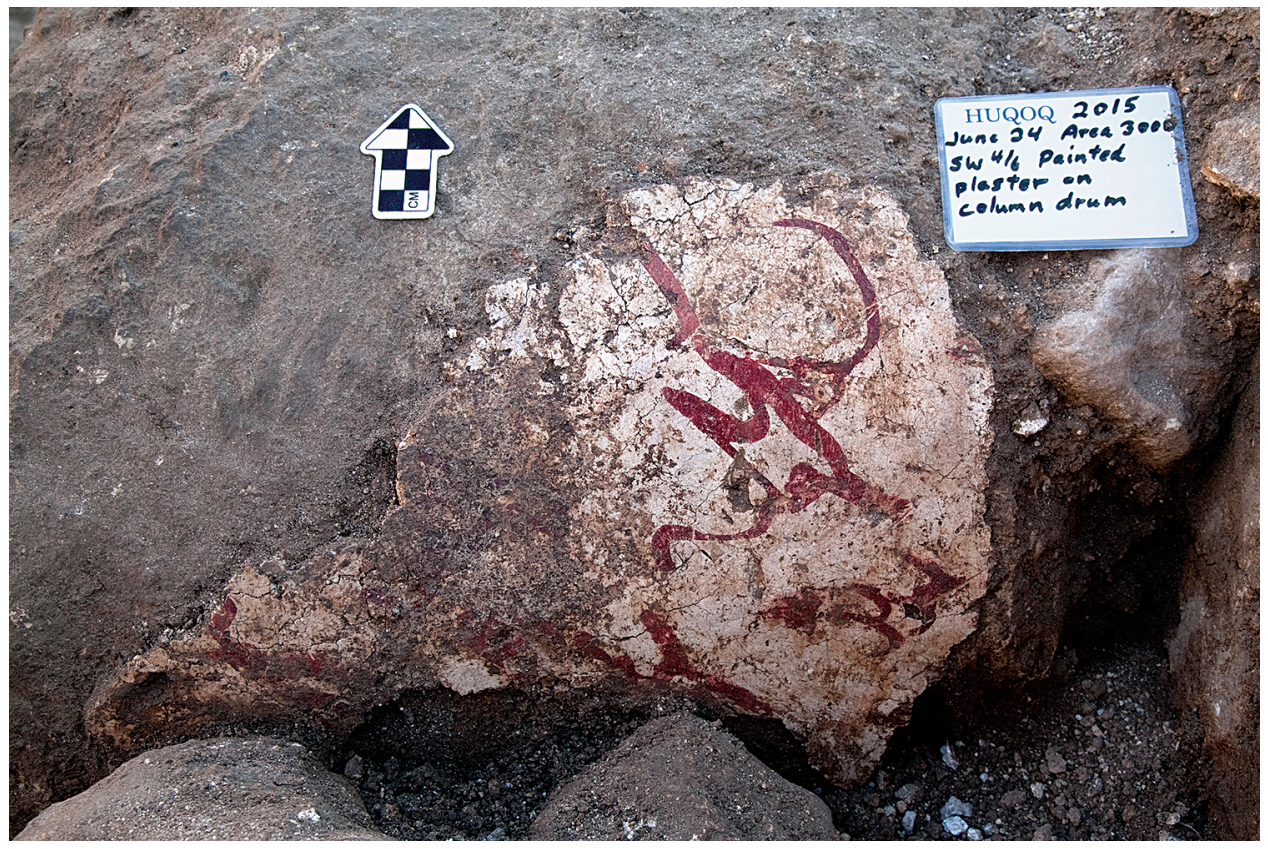

Fig. 29. Area 3000: painted column drum from the Late Roman synagogue. (Photo by J. Haberman; courtesy of the Huqoq Excavation Project)

and help the new coat adhere also provide evidence of two phases of decoration. ${ }^{26}$

The painted plaster originally covered the surfaces of the walls and columns inside the synagogue, and the abstract motifs may have been intended to provide visual support for the more elaborate figural mosaics. The fragments of painted plaster exhibit three decorative types: solid red or white, curving red lines on a white background, and composite daubs of pink, red, orange, and white. In all three types, the pigment appears to have been applied very freely. Visible brush marks and variation in the hues of pigments, such as white, pink, and red, appear to be the result of colors mixing during the application of paint. Copious paint drips and splotches also suggest a haphazard approach. At present, no figural ornament is visible in the painted plaster. Based on the organic quality of the motifs, particularly of the long, looping, and curving red lines on a white background, it is possible that the painter had intended to create a vegetal motif or even a very abstract version of imitation marble, ultimately derived from Roman models. The quantity of painted plaster at Huqoq as well as its preservation on column drums make it an important source of evidence for surface decoration in Late Roman and

${ }^{26}$ The painted plaster from the Rehov synagogue displays similar evidence of two phases of painting (see Vitto 2015: 5-8).
Byzantine synagogues and the tradition of painting in ancient Palestine.

As we have not dismantled the medieval public building's stylobate, many of the architectural pieces under it are unexposed or incompletely exposed. The exposed, accessible, and documented pieces include the capital and drum of a Doric-style column and a battered but quite large Corinthian capital, and two large pedestals for columns. The number and variety of column bases and pedestals (as many as four different styles) and capitals (as many as three different styles) present several possible reconstructions involving porch or courtyard areas, second stories, or even more than one construction phase. Three fully preserved voussoirs (and fragments of at least one other), decorated with dentil, egg-and-dart, and bead-and-reel motifs, indicate that there was a large arched window, presumably over the main doorway in the synagogue's south wall.

At least two architectural features might be associated with liturgical furnishings added to the synagogue after the mosaics were laid. The first is a finely carved stone pedestal $(0.59 \times 0.59 \times 0.43 \mathrm{~m})$ with an hourglass profile that was placed directly above the northwest corner of the mosaic panel depicting Jonah and precisely even with the line of the synagogue's west stylobate. The purpose of this pedestal is unknown. One possibility is that it was the platform for a freestanding marble menorah found 
nearby (see below). However, its placement on the line of the west stylobate complicates this arrangement, as it would require that the menorah be displayed parallel to the stylobate rather than perpendicular to it (as would be expected to maximize its visibility to the congregation).

The second feature consists of two cut ashlar blocks laid end to end, creating a step rising from west to east and together measuring $1.15 \mathrm{~m}$ in length. The blocks were set in plaster mortar on top of the southeast corner of the mosaic panel depicting the Tower of Babel, along the line of the west foundation trench of the medieval public building's east stylobate. The plaster mortar outline of another (missing) block extending to the south is also visible on the mosaic. These blocks appear to represent a larger feature that was deliberately placed and plastered on top of the mosaic floor after it was laid but while the Late Roman synagogue was still in use. Although the nature of the feature represented by these blocks is currently unknown, the location suggests that it might have been part of a bema added to the synagogue nave in a secondary phase of the building. ${ }^{27}$ The feature appears to have been dismantled with the construction of the medieval east stylobate, and the surviving blocks were incorporated in the west side of a medieval buttress.

Large quantities of rubble and stone fragments covered the mosaic floors at the southern end of the synagogue. These include a small, finely worked limestone or marble column base and an abbreviated Corinthian capital, and many fragments of finely worked columns of similar scale. The possibility that there was later specialized construction here, such as a bema, is supported by the small capital, base, and column fragments. ${ }^{28}$

Among the rubble on the southwest side of the nave was a fragment of a 3D freestanding marble menorah, consisting of a segment of a slightly curving branch that would have extended from the stem. One side of the fragment is carved in relief with the hind leg and tail of a lion. A possible menorah base fragment made of a different type of marble was found in proximity to the branch. If the latter is indeed part of the base, it may be that the menorah was made by connecting different pieces of the base, stem, and branches, as seen in the comparable segments of a marble menorah found in the synagogue at $\mathrm{Ma}^{\prime}$ on (Amit 1998: xvi-xvii, 155-68). Although fragments of freestanding marble menorahs were discovered previously in three synagogues in the southern part of the country (Khirbet Susiya, Eshtemoa', $\mathrm{Ma}^{\mathrm{C}}$ on), one

\footnotetext{
27 See, e.g., the bema added on top of the mosaic floor in a secondary phase in the Wadi Hamam synagogue (Leibner 2010: 230).

28 These fragments did not originate in a second-story gallery, as the diameters are too small to bear any serious loads like a roof and are concentrated at the southern end of the nave rather than being distributed throughout the hall.
}

synagogue on the coastal plain (Khirbet ed-Duheisha), and one synagogue in the Upper Galilee (Meroth), the Huqoq menorah is the first example of its kind published from the Lower Galilee. ${ }^{29}$ Because the collapse in which the fragments were discovered continues westward into an unexcavated part of the synagogue, it is possible that additional pieces will be recovered in future seasons. A detailed report of the menorah will be provided in a forthcoming publication after this area has been fully excavated. ${ }^{30}$

\section{The Mosaics \\ By Karen Britt and Ra'anan Boustan}

The nave and aisles of the Late Roman synagogue are paved with mosaics depicting figural scenes that are arranged in panels. In 2015, the removal of balks in the east aisle exposed additional portions of mosaics. So far, most of the east aisle (except for the northern end) and nearly all the nave (except for the southern edge) have been exposed. The following discussion begins with mosaics discovered in the east and west aisles in 2014 and 2015 , and then proceeds from north to south in the nave.

\section{Mosaics in the East Aisle}

In 2012, a patch of mosaic preserving part of a Hebrew or Aramaic inscription in a medallion, flanked by female faces, was discovered. In 2013 and 2014, the majority of a mosaic panel divided into three registers (the "elephant panel," with its western/upper edge cut by the foundation trench of the medieval public building) was uncovered (see Magness et al. 2014). All of the mosaics were backfilled at the end of the respective excavation seasons. During the 2015 season, the backfill above these mosaics and the balks between the two scenes were removed. This process exposed the entire elephant panel, specifically its western part, and the remainder of what we provisionally refer to as the "commemorative panel" (Fig. 30).

The Elephant Panel. As the authors have dedicated a monographic study to the elephant panel (Britt and Boustan 2017), here we offer an abbreviated description

\footnotetext{
${ }^{29}$ For freestanding marble menorahs from other ancient synagogues in Palestine, see Yeivin 1974: 201-9; 1989: 94, figs. 12, 13 (Susiya); 2004: 81-82, 156, fig. 33 (Eshtamoa'); Amit 1998 (Ma'on); 2008: 15-16, figs. 9, 10 (Khirbet ed-Duheisha); and Ilan and Damati 1987: 50 (Meroth). In addition, a freestanding menorah carved from stone (but not marble) was found at Hammath Tiberias A (see Hachlili 2013: 303). For a carved marble menorah in the round from the Sardis synagogue (Asia Minor), see Seager and Kraabel 1983: 171.

${ }^{30}$ The menorah will be published by Grey.
} 


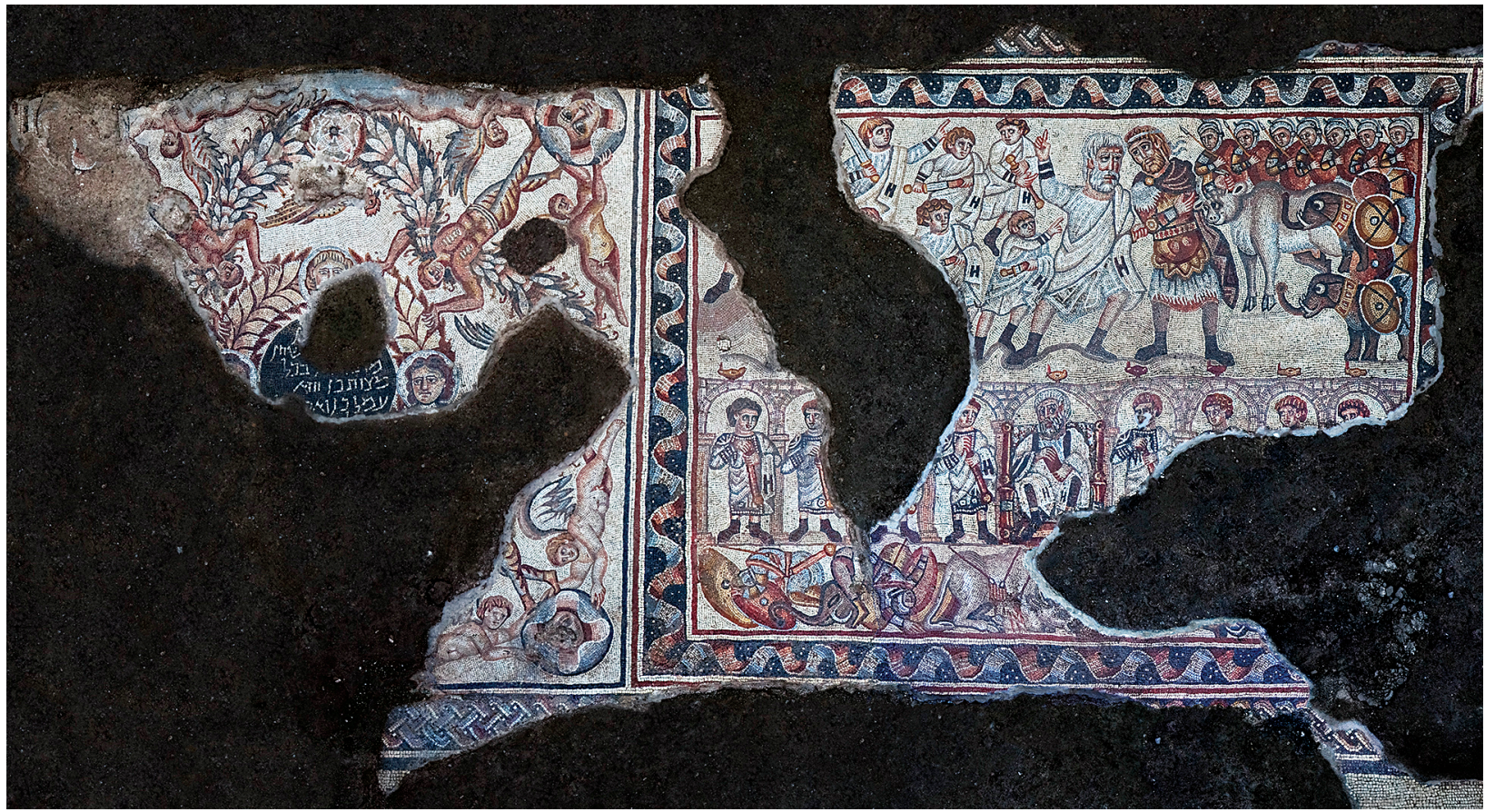

Fig. 30. Synagogue's east aisle: the elephant panel (right) and commemorative panel (left). (Photo by J. Haberman; courtesy of the Huqoq Excavation Project)

and analysis of this enigmatic and highly complex work. The panel is divided into three registers of unequal size (Fig. 31). In the authors' view, the narrative depicted in the panel unfolds from bottom to top. ${ }^{31}$ The bottom register is the smallest of the three and the most explicitly violent. Beginning on the left-hand side, a soldier has been slain by the javelin protruding from a bloody wound in his back. To his right lies a dead elephant. The elephant carried a rider whose torso has likewise been pierced by a javelin and is depicted falling backward off the pachyderm. The rider is outfitted in the same armor as the fallen soldier but wears short boots instead of the greaves of an infantryman. Adjacent to the elephant and rider, a dead bull lies on the ground. He has been felled by three javelins, which remain in the gaping wounds on his side. The iconographic similarities between the fig-

${ }^{31}$ There are no hard and fast rules for the arrangement of narratives in floor mosaics. While Britt and Boustan argue that the elephant panel should be read from bottom to top, geographically and temporally proximate pavements were intended to be read according to other organizational principles. A mosaic from the villa at Soueidié (near Baalbek, Lebanon), depicting scenes from the life of Alexander the Great, begins in the center of the panel and proceeds chronologically in a clockwise fashion (Chéhab 1958-1959 1: 29-52 [text]; 1958-1959 2: pls. XI-XXVI [plans and illustrations]), while the looted Syrian mosaic wanted by Interpol, depicting historical scenes of the founding of Pella/ Apamea, proceeds chronologically from top to bottom (Olszewski and Saad 2017). ures in the bottom register and those on the right-hand side of the top register indicate they belong to the same group. This group has been dealt a resounding defeat in the battle scene of the bottom register.

The middle register is formed by the placement of an arcade above the bottom register. Eight standing male figures and one seated male figure are framed by nine arches, each with a lighted oil lamp above it. In the central arch, an enthroned white-haired male figure gazes out obliquely at the viewer. His white hair, moustache, and beard as well as his axial alignment with the whitehaired leader in the top register make clear that he represents the same person. He holds a scroll with both hands. To each side of the enthroned figure, four young men grasp the hilts of their sheathed swords with their right hands and hold the top of the scabbards in their left. The number of young men, their individualized heads, and the details of their dress signal that, like the white-haired leader, these are the same figures as depicted in the lefthand group of the top register.

A scene depicting an encounter between the two groups of men is preserved in the top register (Fig. 32). Each group is led by a male figure whose importance to the scene is communicated by his large size and central position. The members of each group halt and gaze expectantly at the dramatic meeting of their leaders. It is this moment of rapprochement that forms the 


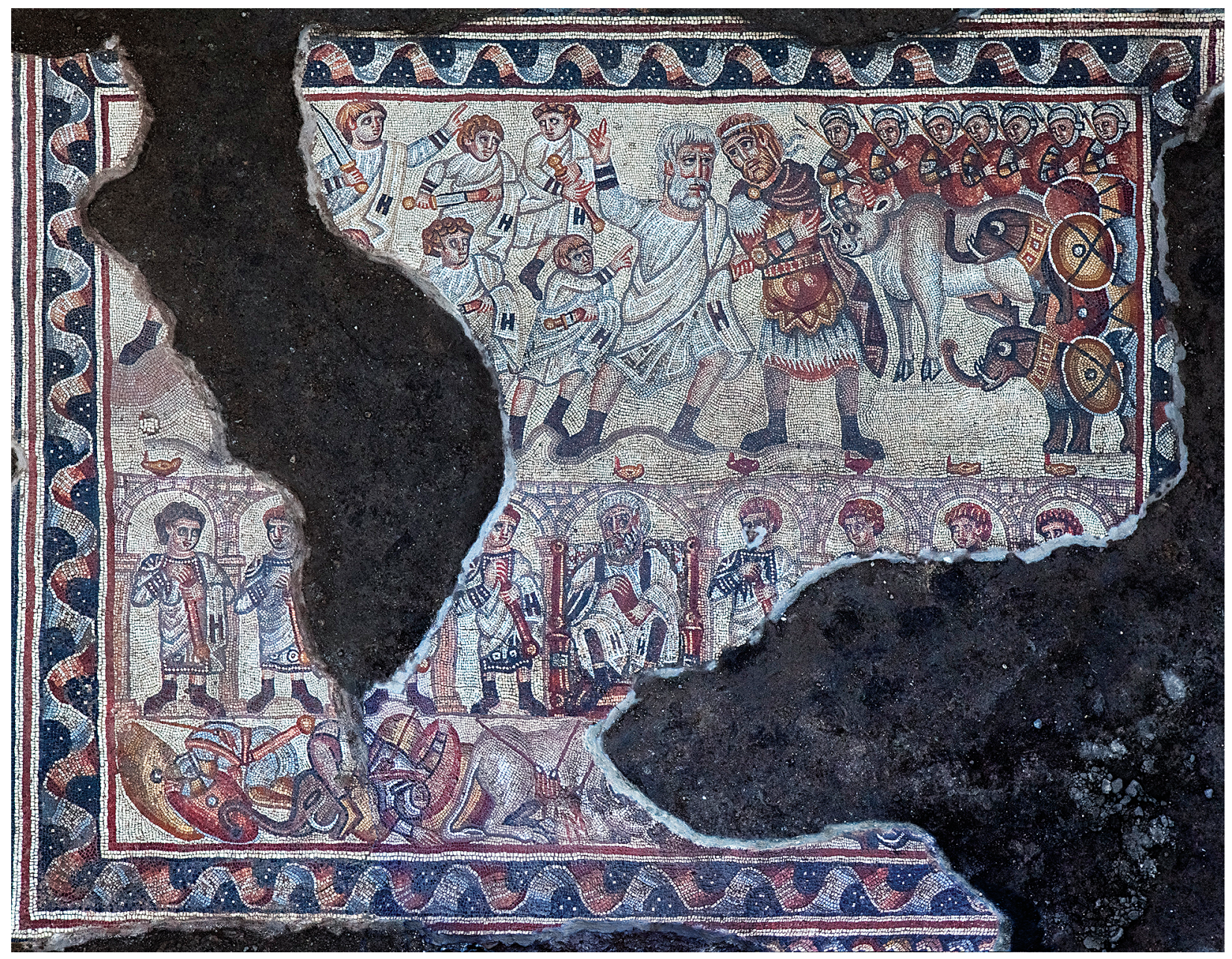

Fig. 31. Synagogue's east aisle: the elephant panel. (Photo by J. Haberman; courtesy of the Huqoq Excavation Project)

focal point of the top register as well as the climax of the larger narrative depicted in the panel. The left-hand group originally consisted of eight young men holding swords. Although the young men have abruptly stopped, they maintain active stances. The leader differs from his followers in size and age, though his dress is the same. With his wide stance, raised right arm, and pointing finger, he commands attention by pointing directly up at what, in the context of the scene, must be the sky overhead. The leader's high social status as an office-holder is reinforced by the direct and unflinching quality of the gaze with which he greets the military commander, suggesting his equivalent status. ${ }^{32}$ The leader holds an object, perhaps a coin or sword, in his left hand, which he offers to the other figure.

${ }^{32}$ On direct eye contact as a sign of equivalent status, see Quintilian, Inst. 11.3.72.
The leader of the group on the right-hand side wears the dress and insignia of a king or emperor on military campaign - namely, a cuirass, purple chlamys, and diadem. The specific combination of a purple cloak and cuirass encircled by an ornately decorated belt is distinctively Late Roman and imperial, as exemplified by portraits of the Tetrarchs (Bodnaruk 2015). The king is taller than the other leader, although, in an inversion of normal practice, he inclines his head toward his counterpart in a display of deference. With his right hand, the king gestures toward a bull whose horn he grasps with his left hand. The combination of the king's gesture and his gaze signals that the bull is being offered to the whitehaired leader. The bull stares directly at the object that the white-haired leader gives to the king, thereby underscoring the reciprocal nature of the exchange.

The upper right corner contains a phalanx of armed soldiers. The uniformity of the soldiers' appearance and posture contrasts markedly with the display of individu- 


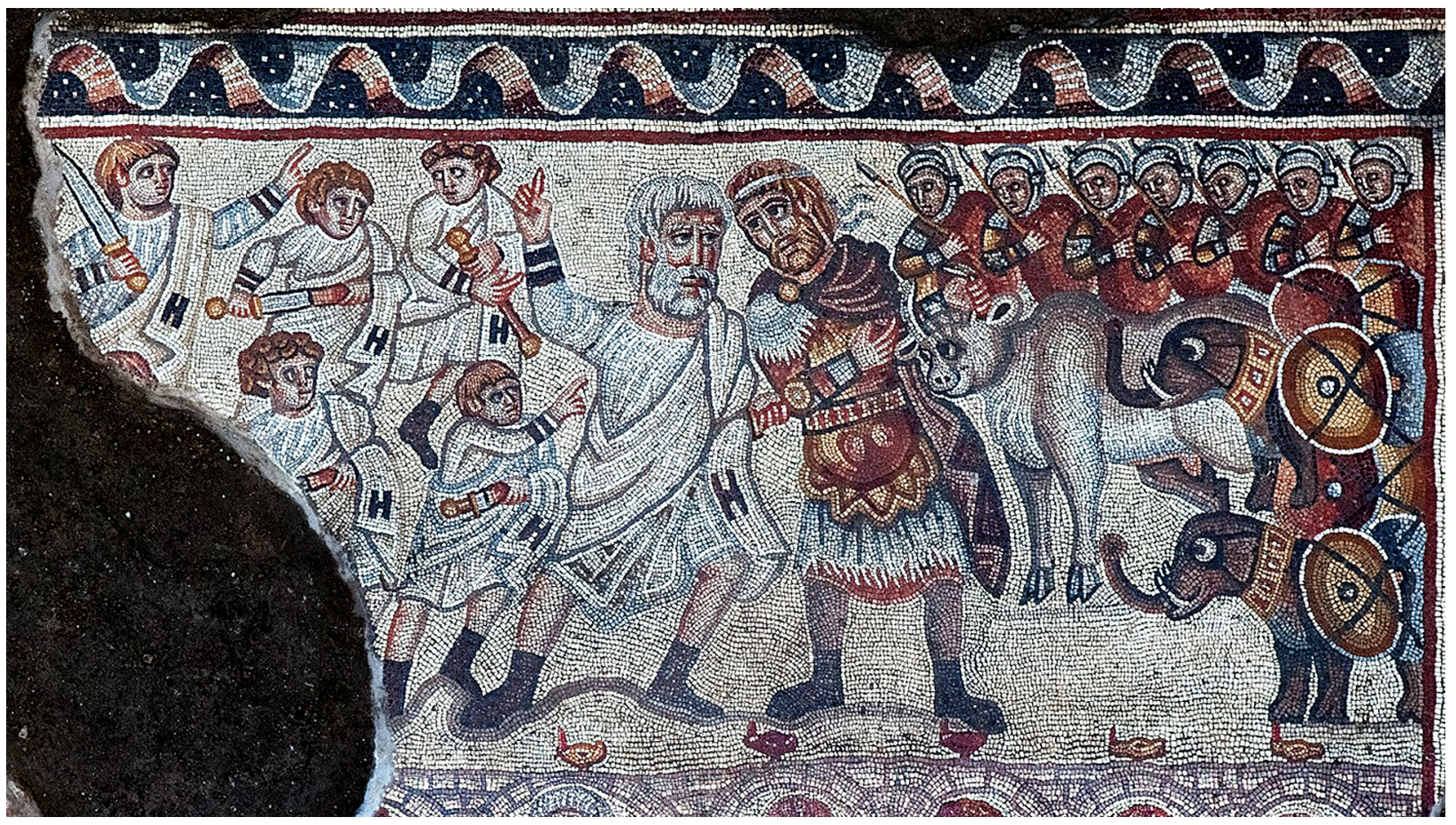

Fig. 32. Synagogue's east aisle: upper register of the elephant panel. (Photo by J. Haberman; courtesy of the Huqoq Excavation Project)

alism in the men on the left-hand side of the scene. But as in the left-hand group, the stances and gestures of the soldiers direct the viewer's attention to the exchange between the leaders. Beneath the phalanx, two elephants are outfitted for battle. The presence of the phalanx, battle elephants, and the diadem worn by the right-hand leader suggests that he is a Greek king, not a Roman emperor. His dress is not Hellenistic but instead conforms to what was worn by emperors in late antiquity, in keeping with the modes of contemporization in late antique art.

Although there are no inscriptions identifying the episodes represented, the presence in the top register of battle elephants and a Greek king wearing a diadem and purple cloak sets the elephant panel apart in the corpus of ancient synagogue art. In all other synagogues, the subject matter depicted in narrative scenes derives from the Hebrew Bible. By contrast, the composition and iconography of this panel suggest that it portrays a historical event, either real or invented, from the late classical or Hellenistic period. The memorialization of a non-biblical event in a synagogue challenges scholarly assumptions concerning the historical consciousness of Jews in late antique Galilee, indicating that perhaps Jewish knowledge of the past was not circumscribed by the horizons of the biblical narrative. In a recent publication (Britt and Boustan 2017), the authors explored various possible interpretations of the elephant panel, including the depiction of a scriptural narrative, either from the Hebrew Bible or as retold elsewhere in Jewish or Christian traditions; events from the period of the Maccabean revolt, especially the associated martyrdom traditions (which Grey favors); and the legendary meeting between Alexander the Great and the Jewish high priest (which Magness believes). While the authors do not rule out these interpretive possibilities, Britt and Boustan believe they do not adequately account for several of the panel's most notable features-in particular, the bloody defeat of a Greek army (in the bottom register) by an unseen foe and the offering of a bull by the Greek king (in the top). They ultimately identify the subject of the panel as a narrative depiction of the Seleucid siege of Jerusalem under Antiochus VII Sidetes and the subsequent military alliance between the Seleucids and the Hasmonaean high priest, John Hyrcanus. ${ }^{33}$ In the authors' view, this historical event from the Hasmonaean period best accounts for the specific iconography and composition of the panel (see Britt and Boustan 2017: 62-80).

\footnotetext{
33 The siege of Jerusalem is narrated at length or in abbreviated form in a number of sources in Greek and Latin, most notably, Josephus, B.J. 1.61; A.J. 7.393, 13.237-253; Diodorus Siculus 34-35.1.5; and Plutarch, Reg. imp. apophth. 184F. For a discussion of the extant versions and their sources, see Bar-Kochva 2010: 399-439.
} 


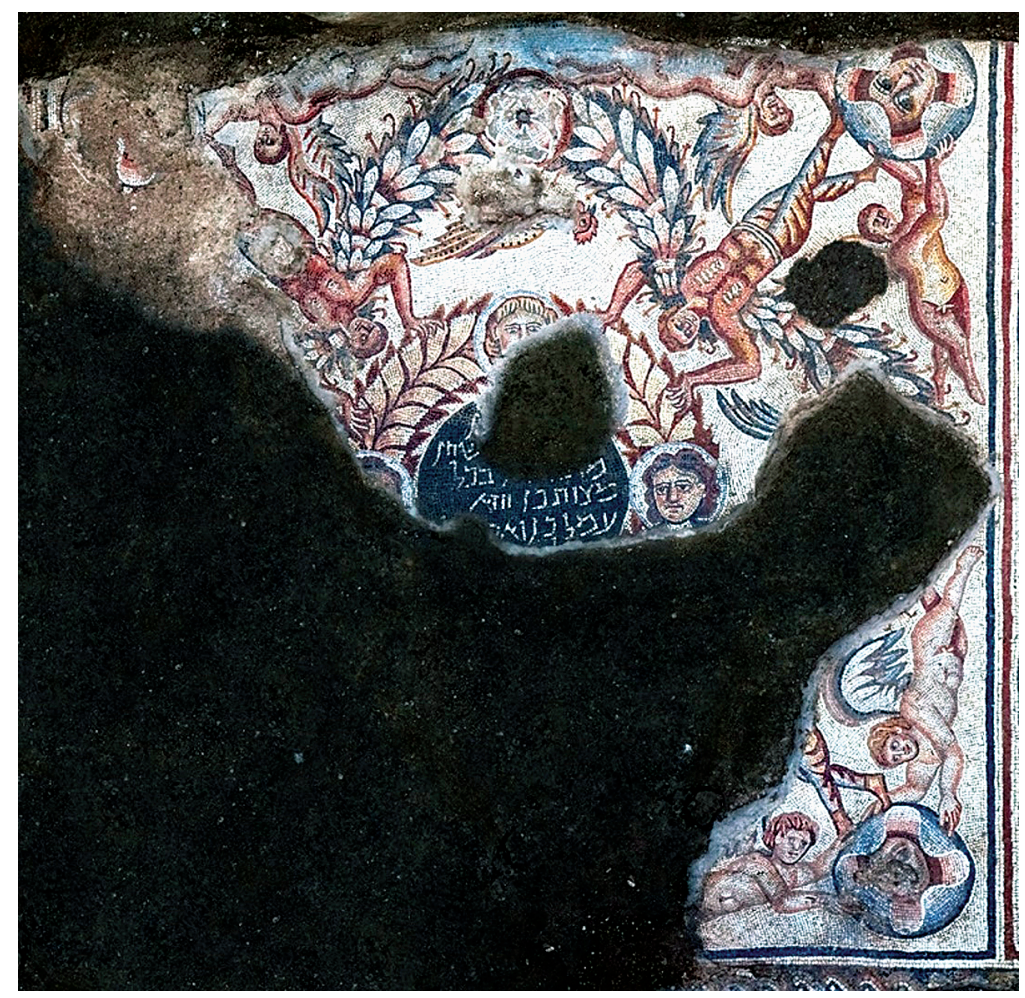

Fig. 33. Synagogue's east aisle: the commemorative panel. (Photo by J. Haberman; courtesy of the Huqoq Excavation Project)

The Commemorative Panel. The removal of the balks also revealed that the inscription flanked by female faces to the south of the elephant panel lies in the center of a symmetrical composition, forming a separate square panel (Fig. 33). Although the southeast corner of the mosaic is missing, its composition can be reconstructed based on the symmetrical design of the panel. The inscription is encircled by a wreath that contains roundels with heads on three sides of the medallion. The heads of the females, initially uncovered in 2012, turn toward the inscription. A third head, likely male, located in a roundel above (west of) the medallion, was uncovered during the 2015 season. The eyes of this figure look down at the inscription. Presumably, a fourth roundel, not preserved, was located below the inscription.

The wreath is held up by four male figures (atlantes) placed in each corner of the panel. They wear tight-fitting trousers belted at the waist, and soft boots. Their upper bodies are bare and display exaggerated pectoral muscles, and their arms raised overhead to support the wreath. ${ }^{34}$ The

${ }^{34}$ A similar arrangement of atlantes (or telamones) appears in the late first- or early second-century black-and-white mosaic paving the frigidarium (C) of the Baths of the Coachmen in Ostia (II.II.3). In the mosaic, four nude atlantes, standing on plinths, support towers figures are connected by a continuous floral garland, which passes over their left shoulders and behind them. ${ }^{35}$ Their feet are positioned on spheres located in each corner of the mosaic panel. The spheres are inscribed with human faces or masks. ${ }^{36}$ Each sphere is held aloft by two winged putti.

Although only partially preserved, the inscription likely commemorates the construction of the synagogue by blessing those who adhere steadfastly to all Jewish commandments (the mitzvot) or, alternatively, those who made charitable donations to the project (Fig. 34). ${ }^{37}$

located at the corners of the city wall. For an illustration, see Stöger 2011: 223, fig. 9.3.

${ }^{35}$ A similar continuous garland with birds frames the mosaic of Artemis and Actaeon from Shahba-Philippopolis. Unlike that at Huqoq, the Shahba-Philippopolis garland is supported on the left shoulders of winged figures of Attis in the four corners of the square panel. On this mosaic, see Balty 1977: 20-23, figs. 5, 6; 1995: 142, pls. VI.2, VII.1.

${ }^{36}$ Two (of the four) faces or masks are in an excellent state of preservation, while a third has suffered considerable damage. Like the rest of the southeast quadrant, the fourth visage has not survived.

${ }^{37}$ For the initial decipherment, see Amit 2013, in which the author reads the inscription as Hebrew rather than Aramaic, an identification with which we tentatively agree. David Amit translated the partially reconstructed phrase מתחזקין בכל מצות as "adhere to all commandments," which he interpreted as referring to the performance of Judaism's normative legal-ritual prescriptions. But this collocation 


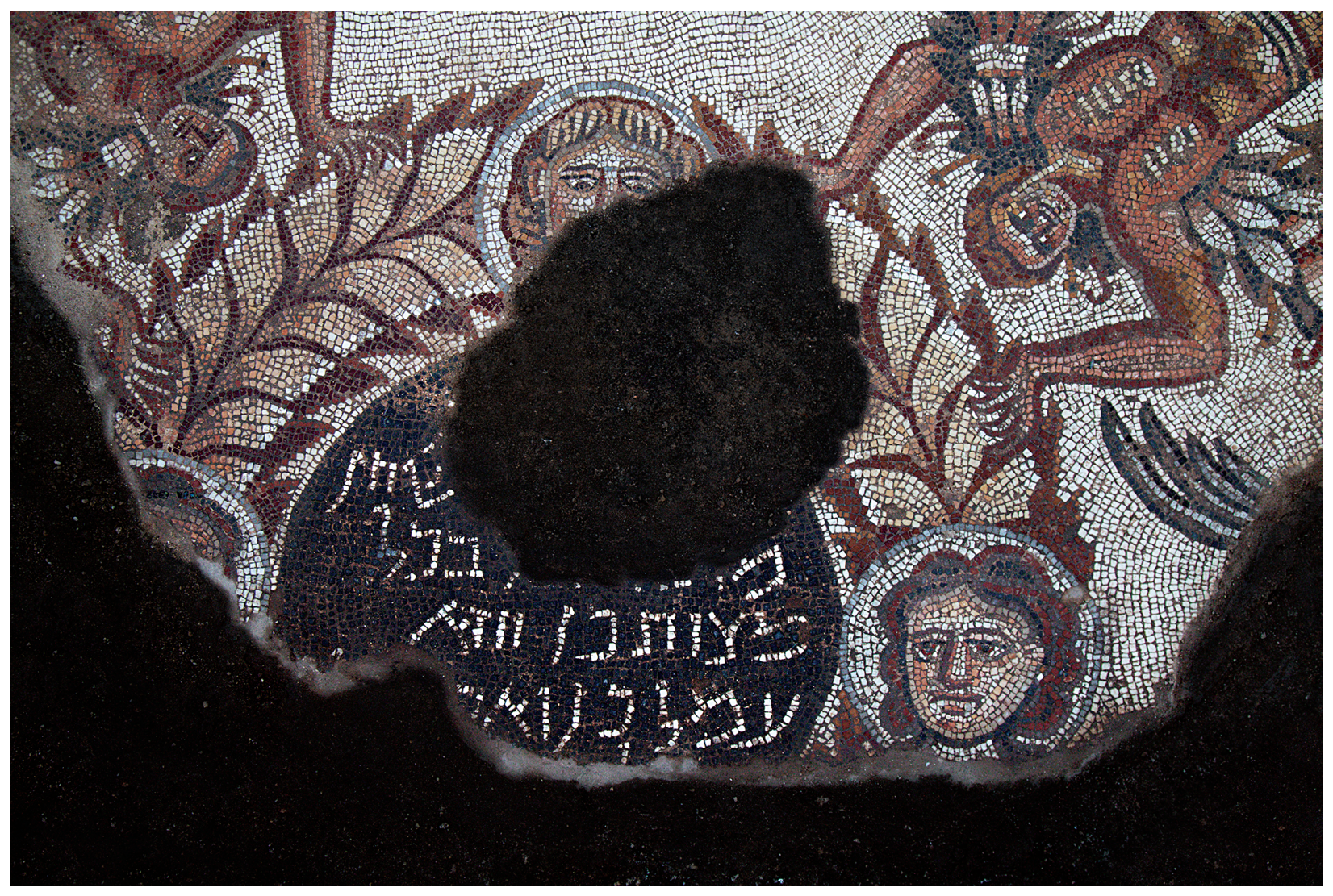

Fig. 34. Synagogue's east aisle: inscription and surrounding wreath in the commemorative panel. (Photo by J. Haberman; courtesy of the Huqoq Excavation Project)

The composition of the panel directs the viewer's attention to the medallion in the middle, underscoring the centrality of the inscription. This compositional arrangement has parallels in both floor mosaics and mosaics on ceilings. As compared with the view of a ceiling vault, a 3D substrate, the viewing experience of a floor mosaic is collapsed to two dimensions. In Room 1 of the Constantinian villa (4th century) at Daphne (Antioch), the composition is arranged to emphasize the octagonal pool at the center of the large panel (see Levi 1947 1: 226-56; 1947 2: pls. LII-LXI, CLX-CLXI; and Dunbabin 1999: 163, n. 9). The square mosaic is divided along the diagonals by full-length personifications of the seasons, who stand on acanthus "pedestals." These diagonal divisions create trapezoidal spaces that are filled with hunting scenes. The Huqoq panel is similarly divided along

may instead refer to the fulfillment of charitable pledges (mitzvah as tzedaqah) for the construction or repair of the synagogue; see the discussion and references to similar phraseology in other synagogue inscriptions and literary texts from late antiquity in Friedman 1984: 605-6. This difficult and fragmentary inscription requires further work. the diagonals by the atlantes, leaving trapezoidal spaces filled with a garland, birds, and winged putti. The presbytery vault mosaic in the Church of San Vitale (547 C.E.) in Ravenna offers a 3D formulation of the floor mosaic compositions at Huqoq and Daphne (see Deliyannis 2010: 249, fig. 87). At the center of the vault, a lamb is framed by a wreathed medallion. The vault is divided into four sections by bands of diagonal garlands that extend from the central medallion. Each of the four trapezoidal spaces between the bands contains four angels standing on blue orbs with arms raised above their heads to support the central medallion. The angels are set within a dense background of vine scrolls and birds. The iconographic elements used in the Huqoq panel-a wreath with heads that may represent the seasons, garlands, birds, masks, putti, and atlantes-are commonly found in Roman commemorative art. ${ }^{38}$ These elements

38 These commemorative contexts include funerary art. See, e.g., the 2nd-century Dokimeion Garland Sarcophagus in the Walters Art Museum (http://art.thewalters.org/detail/30186/garland-sarcophagus/), which contains heavy swags of garland supported on the corners by 


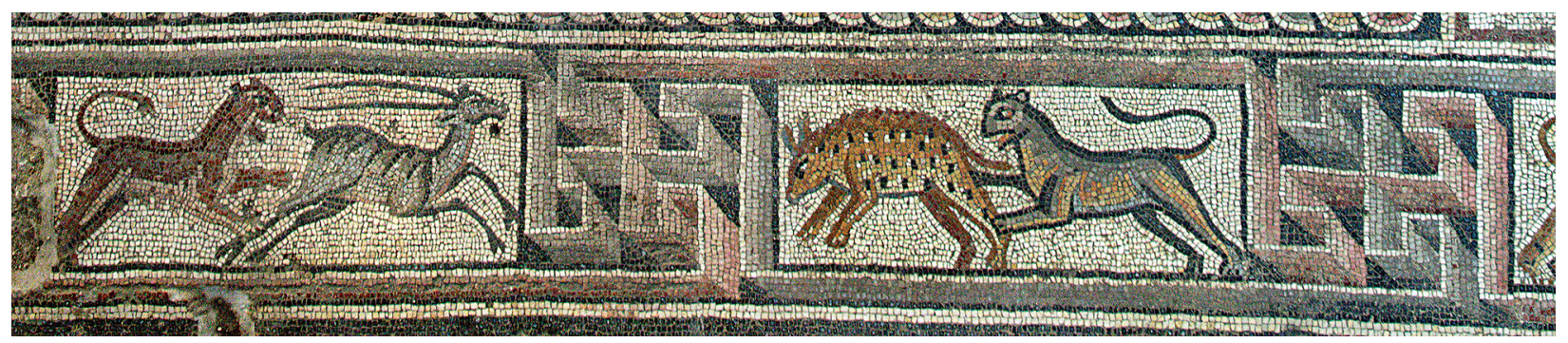

Fig. 35. Synagogue nave: animal chase scenes and perspectival meander border. (Photo by J. Haberman; courtesy of the Huqoq Excavation Project)

reinforce the act of commemoration in the inscription at the center of the Huqoq panel.

\section{Mosaics in the West Aisle}

Part of a mosaic panel exposed in a small sounding in the west aisle in 2015 is divided into two horizontal registers depicting the harvesting of dates. ${ }^{39}$ The upper register contains a row of six date palms, each bearing two clusters of dates. Stone vats for the production of date syrup or wine stand between the trees. At the southern end of the exposed area of the upper register, a male figure is depicted carrying a jar on his shoulder. He wears a short tunic tied on one shoulder, leaving bare his legs and part of his upper body. The lower register contains a row of nine date palms. A male figure perched in one of the treetops uses a dagger tucked into his loincloth to cut the clusters of dates. He lowers the clusters by sliding them down a rope to a similarly dressed male companion on the ground below. As only part of this mosaic has been exposed, it is impossible to determine if it is part of a biblical story or a scene from everyday life. If the latter, this would be the first example of a scene from everyday life found in the decoration of an ancient synagogue.

\section{Mosaics in the Nave}

The mosaics exposed in the nave are oriented toward a viewer entering through a main door in the center of the synagogue's south wall and looking toward the north end of the hall. The panels are enclosed within a partially preserved wide border on the west side. This elaborate border is composed of rectangular panels depicting ani-

winged goddesses or personifications and on the sides by putti. Theater masks depicting tragedy and comedy appear at the center of the front and back sides. For a monographic study of garland sarcophagi, see Işik 2007. On the social reception and interpretation of sarcophagus iconography, see Zanker and Ewald 2012: 1-56.

39 This mosaic is not illustrated, as it has not yet been fully exposed. mal chase scenes, alternating with squares of a perspectival geometric meander motif (Fig. 35). Although not preserved on the east side of the nave (due to damage by the foundation trench of the medieval public building's stylobate), the same border presumably enclosed the mosaic panels on that side, too. Animal chase scenes appear frequently in the borders as well as in the main fields of floor mosaics in synagogues, churches, and secular buildings in this region. ${ }^{40}$ We focus here on mosaics in and near Galilee as the most suitable comparisons for Huqoq. In the poorly preserved mosaics from the synagogue at Yaphi'a (near Nazareth), the inhabited acanthus scrolls in the main field surrounding the zodiac (and/ or the symbols of the 12 tribes of Israel) appear to have contained predatory animals, as evidenced by the stalking pose of the tiger in one of the roundels (see Sukenik 1951: 17). Parallels for animal chase scenes in the borders of synagogues also include the narthex mosaic of the 5th-century synagogue at Gerasa (modern Jerash in Jordan), where a wide border filled with predatory animals chasing prey surrounds a panel depicting the disembarkation of Noah's sons and the animals from the ark (Biebel 1938). An animal chase border also encloses the central vine scroll mosaic of the synagogue in the House of Leontis at Beth Shean (Bahat 1981). The placement of animal chase scenes in rectangular panels, similar to Huqoq, occurs in the intercolumniations of the Church of the Martyr at Tel Iztaba (Beth Shean) (Mazor and Bar Nathan 1998: 30-31).

The nave pavement consists of five panels depicting, from north to south, pairs of animals arrayed around Noah's ark; pharaoh's soldiers drowning in the Red Sea; a Helios-zodiac cycle; Jonah the Prophet being swallowed by a series of three fish; and the building of the tower of Babel (Figs. 28, 36, 37). In addition to these primary panels, smaller panels at the northern and southern ends

40 On the range of meanings associated with depictions of animal violence, see Maguire 2000. 


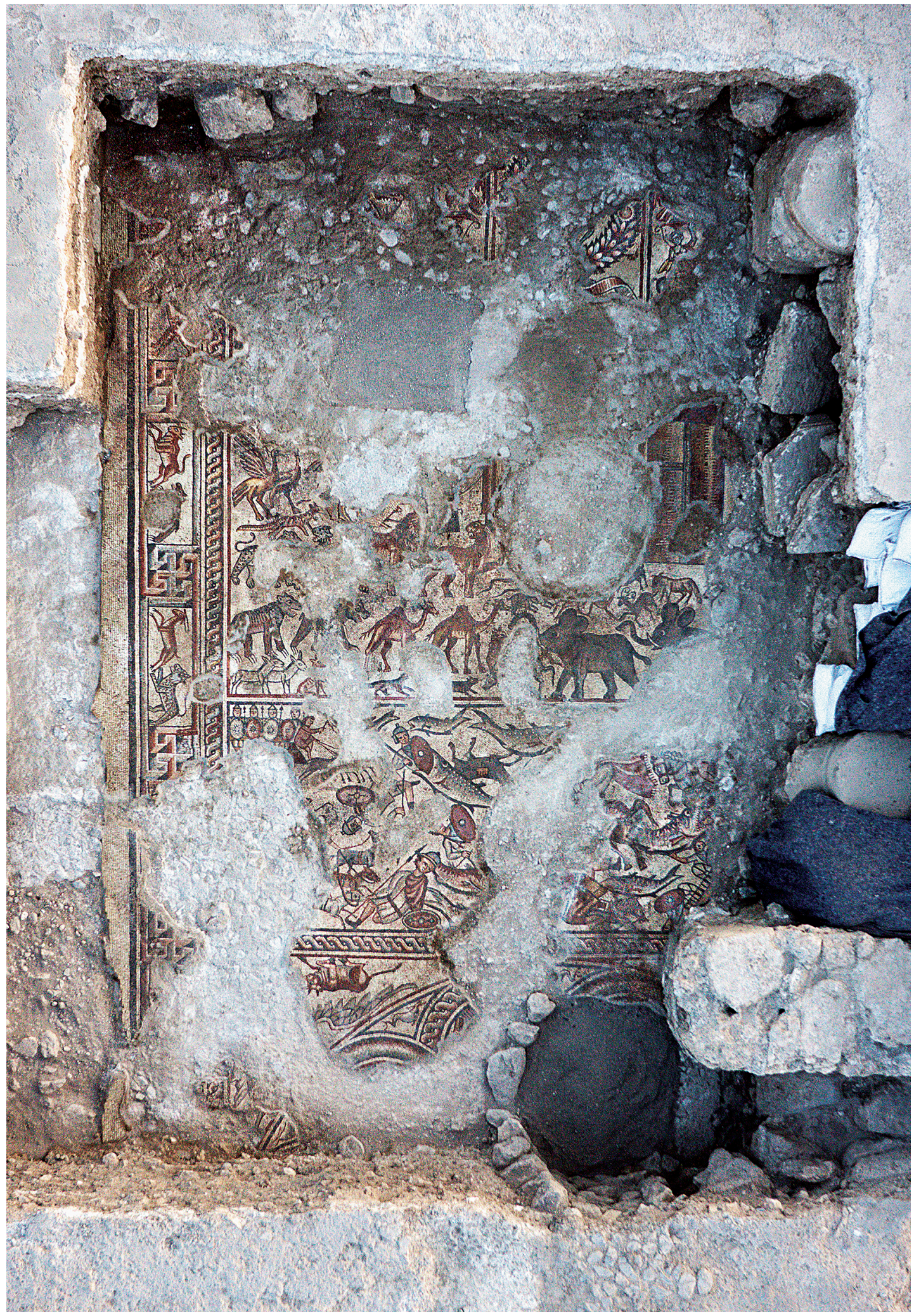

Fig. 36. Aerial view of mosaics in the north half of the nave during the 2016 season (north at top). (Photo by Griffin Higher Photography; courtesy of the Huqoq Excavation Project) 


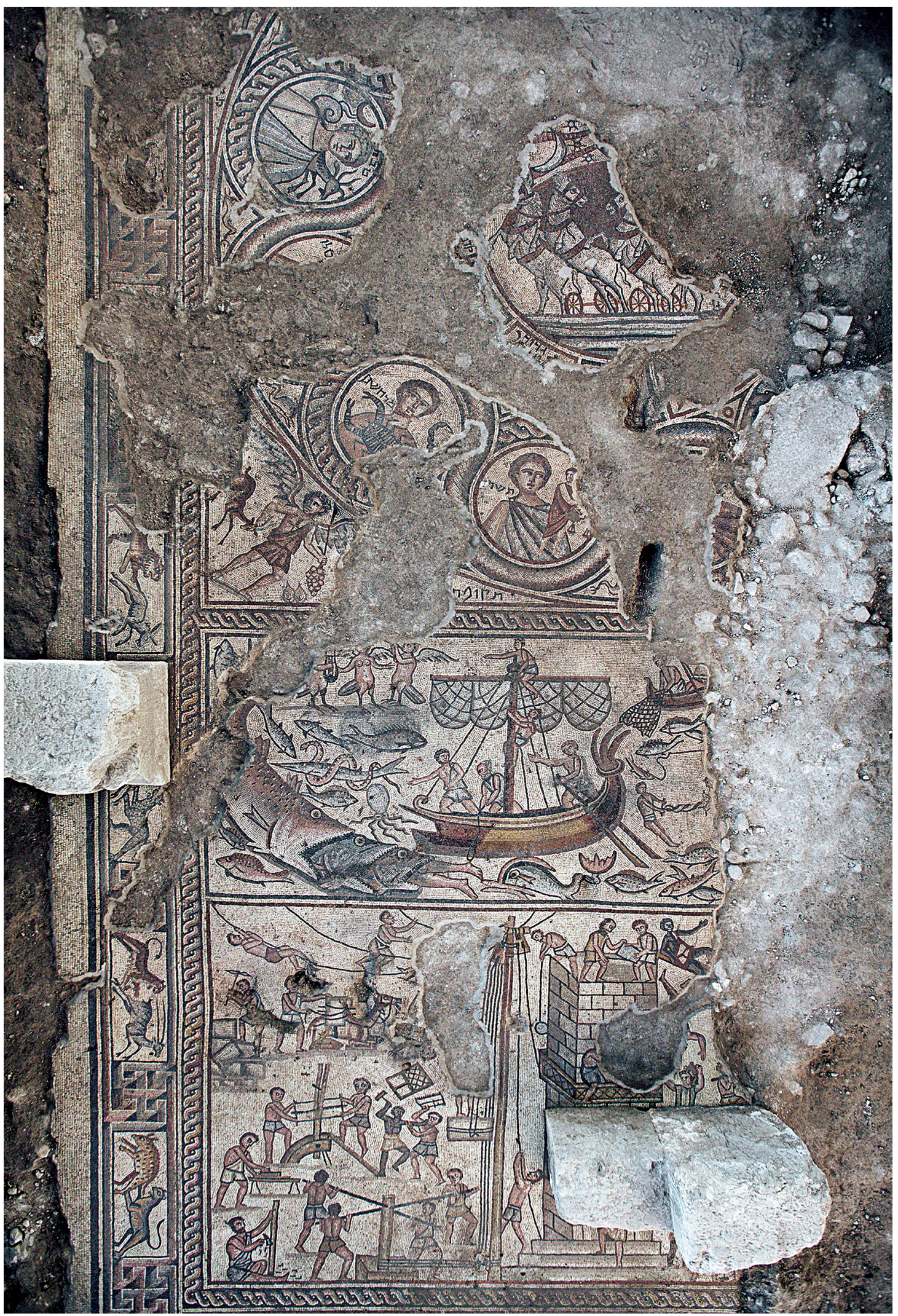

Fig. 37. Aerial view of mosaics in the center and south half of the nave during the 2017 season (north at top). (Photo by Griffin Higher Photography; courtesy of the Huqoq Excavation Project) 


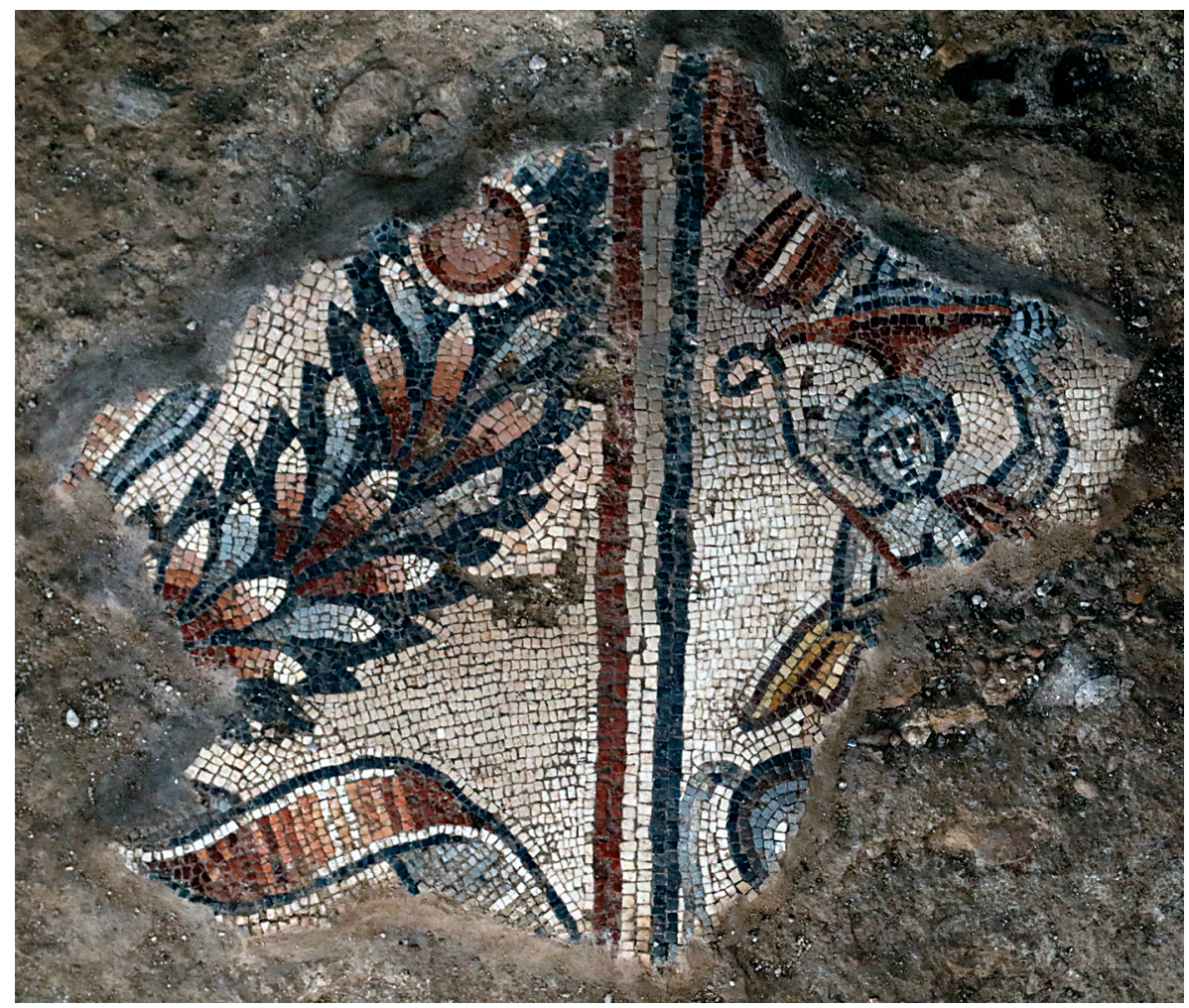

Fig. 38. Synagogue nave: detail of wreath and horse and rider or centaur at the north end of the nave. (Photo by J. Haberman; courtesy of the Huqoq Excavation Project)

of the nave contain lions, eagles, and an inscription enclosed by a wreath. (The panels at the northern end are almost completely destroyed but appear to mirror those at the southern end.) The Helios-zodiac cycle panel at the center of the nave is framed on all sides by a guilloche border. The other panels are framed individually by simple fillet borders.

Panels at the Northern End of the Nave. Fragments of three mosaic panels were uncovered at the northern end of the nave. The panels are arranged in a row, each one framed by a simple fillet border. ${ }^{41}$ The preserved mosaic in the east panel contains fragments of a human figure and a horse (or a human figure with a

${ }^{41}$ During the 2017 season, four side-by-side panels were partially uncovered at the south end of the nave, just inside the line of the synagogue's south wall. These panels include two large lions; two eagles perched on vessels or pedestals placed on top of the heads of centaurs (or riders and horses); and an inscription framed by a floral wreath. This series of panels appears to have been identical to the panels at the north end of the nave and, once fully excavated, will help to illuminate their poorly preserved counterparts. horse's body-that is, a centaur). ${ }^{42}$ The figure supports a vessel on its head with its raised left hand and holds a shepherd's crook in its right hand. A small fragment of mosaic preserved above the vessel appears to depict the wing of a bird (Fig. 38). If this is the case, the composition shares certain similarities with a panel from the southwest corner of the nave of the synagogue at Yaphi' a (near Nazareth), which displays an eagle standing on a volute-shaped pedestal with the head of Medusa at its center (Sukenik 1951: 15-16, fig. 5; Talgam 2014: 316). A marble fragment from an ambo (second half of the 5th century to early 6th century) in the Archaeological Museum at Kavala contains a relief sculpture with a similar

\footnotetext{
${ }^{42}$ Examples of centaurs are found in mosaics in this region. If the Huqoq panel contained a centaur, the nearest parallel-geographically, temporally, and compositionally-is the centaur mosaic (5th century) in the Nile Festival Building (Room 9) at Sepphoris, where the centaur stands on its hind legs and raises its arms in the air to support an object bearing an inscription (see Weiss and Talgam 2002: 73-74 fig. 12). Centaurs are depicted in different poses in Dionysiac scenes in 3rd-century mosaics at the Villa of Dionysus at Sepphoris (Talgam 2014: 33-34, fig. 43) and in the Mosaic of the Muses and Poets at Gerasa (Piccirillo 1992: 282-83, fig. 516).
} 
composition: an eagle with wings outspread stands on a vessel with volute-shaped handles (Maguire 1991-1992: 283-95, figs. 1, 3). In an intriguing twist on the Medusa head at Yaphi'a, the Kavala example has the eagle grasping a snake and small quadruped in its talons (Maguire 1991-1992: 286-88). ${ }^{43}$ The mosaic in the center panel contains a floral wreath preserved in two fragments. The wreath almost certainly enclosed an inscription, which is not extant. The mosaic in the west panel is preserved in three fragments, the easternmost of which contains a human figure bearing a vessel on its head and a crook in its arm-the same image as contained in the east panel described above. Based on their identical subject matter, it is reasonable to assume that these were pendant panels framing the floral wreath. The center fragment in the west panel contains an indeterminate V-shaped object, and the west fragment preserves only a small row of red tesserae set against a white background.

Noah's Ark. The northernmost large panel in the nave depicts Noah's ark surrounded by animals, apparently prior to embarkation (Gen 6:11-7:10) (Fig. 39). The scene is divided into registers containing pairs of animals that are arranged to face the center of the panel. The animals appear against a white background devoid of landscape. Five registers are preserved; fragments of mosaic indicate there were additional registers at the top of the panel that are not preserved. The readily identifiable animals include donkeys, elephants, bears, camels, leopards, a lion and lioness, snakes, sheep, foxes, and ostriches. Near the center of the scene, spanning two registers, is the sole fragment of the ark, depicted as a wooden box supported on legs. To the right (east) of the ark is a partially preserved building with a red tile roof. The relationship between the ark and this building is unclear, as the connecting segment of mosaic is damaged by a later pit. ${ }^{44}$

Two other scenes of Noah's ark have been found in ancient floor mosaics (see Hachlili 2009: 65-72; and Talgam 2012: esp. 423-28, figs. 8, 9). One appears in the narthex pavement of the synagogue at Gerasa and is poorly preserved due to the construction of a church over the synagogue in 530/531 C.E. (Crowfoot and Hamilton 1929; Levine 2005: 357-58). The scene depicts the animals and the sons of Noah disembarking from the ark. The animals are arranged in three registers: birds in the top, various animals in the middle, and reptiles and small animals in

43 On the eagle-and-serpent motif as a symbol of victory in Roman art, see Wittkower 1939: esp. 310-11.

44 We tentatively suggest that the building should be identified either as the human habitations that are destined to be destroyed in the flood or as the house of Noah. the bottom. The ark itself apparently was not depicted in this scene. ${ }^{45}$

The other example of Noah's ark is found in a building at Mopsuestia (Misis) in Cilicia, where the scene is better preserved and is identified by an inscription. Since its discovery in 1955, scholars have been divided over whether the building is a synagogue or a church. ${ }^{46}$ The mosaics have been dated from the third quarter of the 4 th century through the 6th century, although the majority of scholars favor a 5 th-century date. ${ }^{47}$ The mosaics preserved in the nave and the outer north aisle of the building at Mopsuestia exhibit striking affinities to the mosaics uncovered at Huqoq. As at Huqoq, the ark in the Noah scene at Mopsuestia is depicted as a wooden chest supported by four legs, is placed at the center of the scene, and is surrounded by animals. Unlike at Huqoq, the wellpreserved Mopsuestia ark has an inscription on the lid that reads "the ark of Noah," and the animals appear in two registers, which are arranged to be viewed from all sides. ${ }^{48}$ The theme of Noah's ark was common on early Christian sarcophagi and in catacomb paintings as well as in late antique manuscript illuminations, where the ark is depicted as a chest. ${ }^{49}$ Noah also appears in the dome mosaic of the 4th-century mausoleum at Centcelles, Spain (Arce 2002; Mackie 2003: 145-53). However, this subject is not represented in the floor mosaics of churches (other than Mopsuestia, if it is in fact a church).

Pharaoh's Soldiers Drowning in the Red Sea. The panel to the south of the Noah's ark mosaic depicts an unusual representation of the parting of the Red Sea (Exod 14:1-15:21) (Fig. 40). The scene, which shows pharaoh's soldiers being swallowed by large fish amid overturned chariots and horses, has particular affinities to the archaic "Song of the Sea" (Exod 15:1-19; cf. Exod 15:21), with its distinctive refrain that the riders, horses, and chariots of

45 As Rina Talgam (2012: 425) observes, there is insufficient space for an ark on the left side of the panel, and an ark on the right side of the panel would not make sense in the context of the disembarkation of the animals (i.e., they face toward the right).

${ }^{46}$ Most recently, Talgam (2014: 321) identifies the Mopsuestia building as a church (see also Budde 1960; 1969; Buschhausen 1972; and Stichel 1978). Ernst Kitzinger (1973) provides no clear answer on the matter. Avi-Yonah (1981) argued that the building is a synagogue.

47 Scholars who favor a 5th-century date include Irving Lavin (1963: 273 n. 424), Kitzinger (1965: 345), André Grabar (1966: 10), and Katherine Dunbabin (1978: 223). For a summary of the relevant bibliography, see Hachlili 2013: 405.

48 The inscription is $\mathrm{K}_{1} \beta \omega \tau$ os $\mathrm{N} \omega \varepsilon$ P. It is unclear for what the rho stands; Talgam (2014: 321) suggests "Redeemer."

49 For images of Noah in a variety of media, see Spier 2007: e.g., cat. 40: Noah and his family in the ark on sarcophagus; cat. 42: Noah on a sarcophagus lid (4th century); cat. 5B, 9B, 10A: Noah in the ark in catacomb paintings; fig. 116: Noah and his family in the ark in manuscript illumination. 


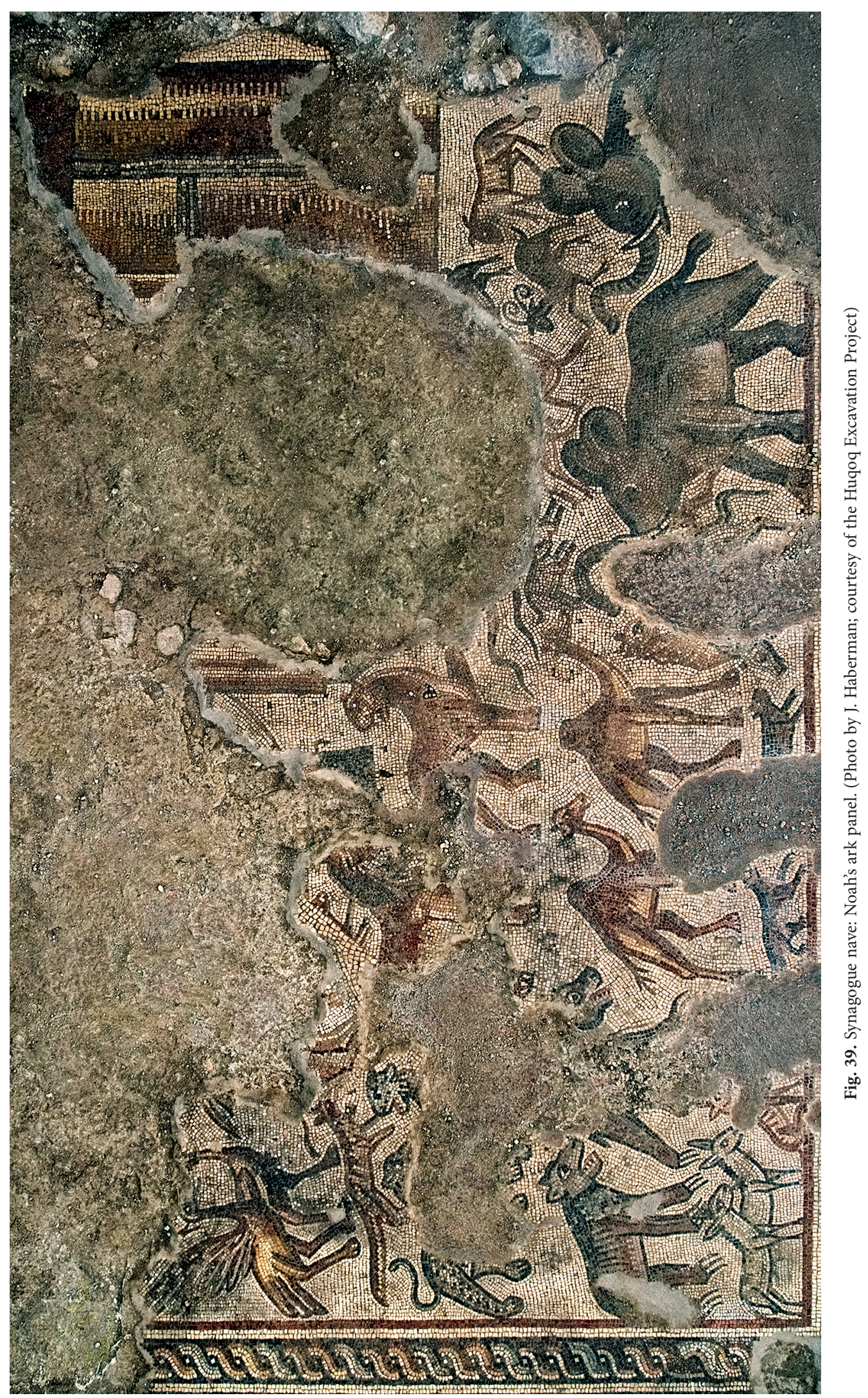




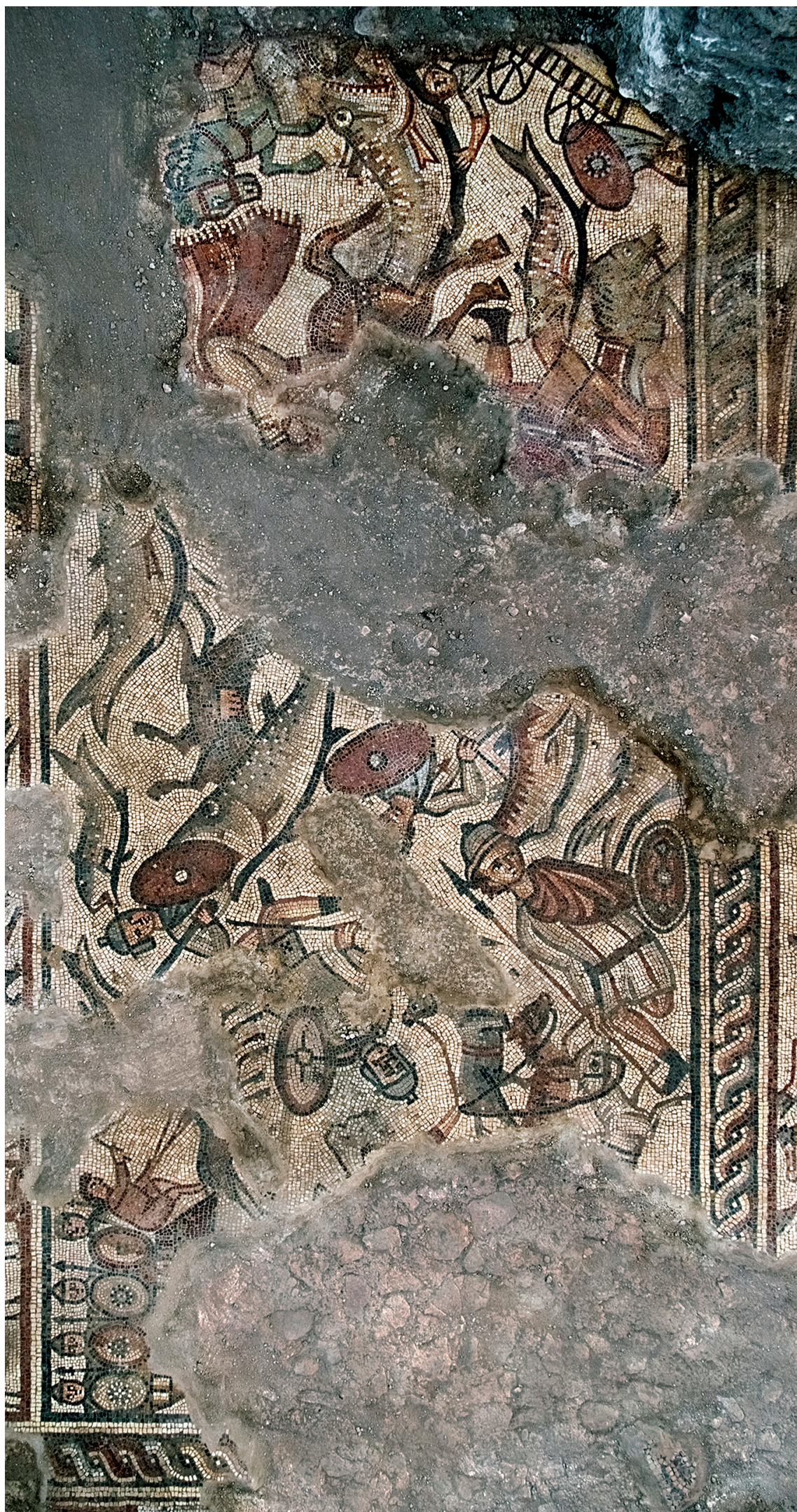


the Egyptian army were cast into the sea. The emphasis in the panel on precisely this aspect of the biblical episode may reflect the recitation of this biblical passage as part of the synagogue liturgy in late antique Palestine. ${ }^{50}$ The figures are shown against a white background devoid of any indication of the setting.

The mosaic contains a series of vignettes in which Egyptian soldiers, wearing Roman military dress, tumble from wheeled carts pulled by teams of horses steered by a driver and are attacked or devoured by ferocious fish or, in the case of a soldier reclining next to his shield at the bottom of the panel, express resignation at their impending doom. Various sizes and species of fish appear in the scene. ${ }^{51}$ At the center of the panel, a large predatory fish, perhaps a barracuda, is depicted swallowing an Egyptian soldier whose upper body, shield, and sword are all that remain visible. To add insult to injury, a small gray fish (mullet?) prepares to attack the same soldier's head with its open mouth. A couple of partially preserved red fish located near the bottom center of the panel may be snapper. On the right-hand side of the mosaic, a bluefish or amberjack displays its sharp teeth, depicted in a redand-white checkerboard motif, as it devours a soldier. Below the bluefish or amberjack, a smaller fish swallows the right leg of an Egyptian soldier falling backward off a horse. Near the top of the right-hand side of the panel (above the previously described fish), two partially preserved riders on horses gallop toward the center.

These small scenes of human, fish, and animal figures are scattered across the panel in a chaotic arrangement that evokes the violent turmoil of the event. The style of the fish in the Red Sea scene at Huqoq has more in common with those in the marine panel from Lod (4th century) than in the mosaics from the Roman villa at 'Ein Yael (3rd century) or the House of the Boat of the Psyches ( 3 rd century) in Antioch. ${ }^{52}$ In particular, the fish at Huqoq and Lod have similar rows of black tesserae on their undersides that form a thick outline intended to be viewed as shadows. A preference for the stark and heavy outlining of figures rather than the use of subtle color gradation as the method for rendering the effects of light on figures and objects is consistent with the stylistic conventions of late antiquity.

\footnotetext{
${ }^{50}$ On the recitation of the "Song of the Sea"-in various forms and at varying points in the liturgy-in the Palestinian rite, see Fleischer 1988: 194-96, 224-26; and Mann 1925: 281-83.

${ }^{51}$ Our preliminary description of the marine creatures in the panel has been aided by Levi 1947: 186, 596-603, pls. 39b, 41; Lightfoot 2010; and Talgam 2015: 64-65.

52 On these mosaics, see Roussin 1995; Kondoleon 2000: 71-74, 152-53; and Talgam 2015: 64-65. For further discussion of the imagery in these mosaics in connection with the Jonah panel, see below.
}

Comparisons of this scene to selected late antique depictions of the parting of the Red Sea highlight the distinctive character of the Huqoq panel. The parting of the Red Sea appears in a 3rd-century fresco from the synagogue at Dura Europos, in 4th-century paintings from the Via Latina catacomb (twice), and in a 5th-century wall mosaic from the Church of Sta. Maria Maggiore in Rome. ${ }^{53}$ At all these sites, the narrative settings for the scene are more fully developed. On the west wall of the Dura synagogue, Moses parts the sea with his rod, thereby allowing the 12 elders and the Israelites to cross (Goodenough 1953-1968 2: color pl. XIV). Moses is depicted performing a second miracle as he stands to the side and extends his staff over the sea, causing the Egyptians to drown in the waters. In the Via Latina catacomb, the scenes (Cubicula $\mathrm{C}$ and $\mathrm{O}$ ) depicting the parting of the Red Sea are similar: the Egyptians, dressed as Roman soldiers, appear on horseback on the left-hand side. On the right-hand side, Moses, standing next to the group of Israelites, turns back to release the sea with his rod (Ferrua 1991: 88, fig. 66; 141, fig. 134). Some of the Egyptians are depicted falling into the sea at the center of the scenes. At Sta. Maria Maggiore, pharaoh's soldiers and charioteers ride out from a walled city representing Egypt. The soldiers and horses are depicted drowning in the Red Sea amid their floating chariots and shields. In this scene, Moses stands at the rear of the group of Israelites and releases the pent-up waters with his rod. ${ }^{54}$

Neither Moses nor the Israelites are depicted in the Red Sea panel at Huqoq. The only known example of a Red Sea scene that resembles Huqoq's is in the nearby synagogue at Wadi Hamam, suggesting a localized repertoire of shared themes. ${ }^{55}$ The relatively well-preserved panel in the Huqoq synagogue offers a fuller representation of the scene than survives at Wadi Hamam. However, the reverse might also be true: the scene at Wadi Hamam may aid in the reconstruction of the Huqoq panel. While the lower corners of the Red Sea panel at Huqoq are not preserved, the panel at Wadi Hamam depicts in its lower left (southeast) corner a walled city with a temple as its focal point (Leibner and Miller 2010: color fig. C on p. 255). Leibner and Shulamit Miller (2010: 258-59) have suggested that this temple represents the sanctuary of the deity Ba'al-zephon, opposite which God instructed the Israelites to camp before crossing the Red Sea (Exod 14:2). Elsewhere, Leibner (2014) has argued

\footnotetext{
${ }^{53}$ In addition, scenes of the parting of the Red Sea appear in early Christian sarcophagi and late antique and Byzantine manuscript illuminations (see the recent discussion of these materials in Spier 2007).

${ }^{54}$ For a color image, see Lowden 1997: 53, fig. 29. For the mosaic program, see Miles 1993.

55 For Wadi Hamam, see Leibner and Miller 2010: 238-64, esp. 257-59.
} 
that this architectural detail specifically reflects rabbinic homiletic traditions, according to which God chose this location so that when the Egyptians went out into the

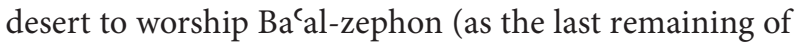
their gods), they would see the Israelite encampment and make the fateful decision to pursue their former slaves into the sea.

Whether or not we accept Leibner's proposal that the panel at Wadi Hamam provides evidence for rabbinic influence on the visual culture of late antique synagogues, he is right to avail himself of rabbinic and other contemporaneous Jewish textual sources to illuminate these scenes. Rabbinic literature attests to the popularity in late antique Jewish culture of the image of the Red Sea as an animated actor in this drama, swallowing and subsequently spewing forth the Egyptian soldiers so that the Israelites might see with their own eyes the corpses of their defeated enemies. ${ }^{56}$ The predatory fish in the panels at the two sites likely were intended to embody the sea's power to consume and then disgorge the drowning soldiers, a theme that may be alluded to in the Babylonian Talmud (and is made explicit in the medieval rabbinic commentarial tradition). ${ }^{57}$ Finally, several rabbinic sources link the punishment of the Egyptians at the sea to a series of other groups or individuals from whom God also exacts measure-for-measure punishment for their hubris, including notably the generation of the flood and those who built the tower of Babel. ${ }^{58}$ If approached with caution, these and other correspondences between visual and textual evidence may enable scholars to make progress regarding the vexed question of how to understand the relationship between rabbinic literature and late antique synagogues.

Helios-Zodiac Cycle. The center of the synagogue nave is decorated with a large square panel containing a Helios-zodiac cycle, a motif depicted in eight other late

56 The motif of the sea swallowing and disgorging the Egyptians is explicit in b. Pesah. 118b. It may also be present in Mek. R. Ish., Beshalah 7 (see Horovitz and Rabin 1997: 113) and several targumim to Exod 14:30 (Tg. Neof., Frg. Tg., Tg. Ps.-J.), each of which inserts the word "cast" before the phrase "on the seashore."

57 See b. Pesah. 118b, Rashi s.v. she-natan lo rabo matanah. This suggestion gains force from the similarities in iconography between the fish in the Red Sea panels at Huqoq and Wadi Hamam and the three fish that swallow-and then presumably would spew out-Jonah in one of the Huqoq mosaics (see below).

58 t. Soțah 3:6-19; Mek. R. Ish., Shirata 2 (see Horovitz and Rabin 1997: 121-25); Mek. R. Sim. b. Yoh. 28.1 (see Epstein and Melamed 1955: 74-75). Interestingly, the list also includes Samson, who is punished for the rebellious use of his eyes by being blinded, while at Huqoq he is seemingly presented as a positive and even heroic figure. For a detailed commentary on the passage from Mekilta de-Rabbi Ishmael, see Goldin 1971: 88-103. antique Palestinian synagogues (Fig. 41). ${ }^{59}$ The compositional arrangement of the Helios-zodiac cycle at Huqoq is rare. The usual arrangement of two concentric circles, with the inner circle containing Helios and the outer circle containing the zodiac signs in 12 equally divided wedge-shaped spaces, has been replaced at Huqoq by interlacing roundels. The only other known example of this compositional arrangement is in the Yaphica synagogue, which is discussed below.

The Helios medallion at the center of the Huqoq mosaic preserves a crescent moon, stars, rays, a four-wheeled chariot, and four white stallions (Fig. 42). Damage to the Helios figure in the chariot makes it impossible to determine whether he was depicted as a personification of the Graeco-Roman sun god (as at Hammath Tiberias, Beth

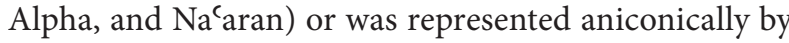
a sun disk (as at Sepphoris). ${ }^{60}$ The stallions, depicted in three-quarters view, rear up on their hind legs, providing a clear view of their bridles, reins, and harnesses. ${ }^{61}$ The bodies of the stallions are turned toward the left (west); their heads face in the same direction, with the exception of the inner left-hand stallion whose head is turned $180^{\circ}$ to look back at the inner right-hand stallion. The orientation of the four stallions' bodies in the same direction (west) departs from their usual arrangement in pairs that face in opposite directions. The depiction of horses rearing on their hind legs and the inner horses turning to gaze at each other, however, is part of the standard repertoire of Helios imagery and appears in other Helios-zodiac mosaics in synagogues, such as Sepphoris, as well as in earlier Roman representations of the zodiac. ${ }^{62}$ The depiction of the chariot with four wheels rather than two is a distinctive feature of the Huqoq medallion

${ }^{59} \mathrm{Na}$ 'aran, Beth Alpha, Huseifa, Hammath Tiberias, Susiya, Sepphoris, Yaphi'a, and Wadi Hamam. In addition, the 'Ein Gedi synagogue inscription (in the narthex) contains a list of the signs of the zodiac and the seasons. For recent discussions of this motif with bibliography, see Talgam 2014: 268-87; and Levine 2012: 319-36. The Huqoq mosaic confirms the identification of the fragmentary remains at Yaphi'a (see below) and Wadi Hamam (Leibner and Miller 2010: 239-40) as Helios-zodiac cycles.

${ }^{60}$ For Hammath Tiberias, see Dothan 1983: 40, pl. 29.1. For Beth Alpha, see Sukenik 1932: 35, pl. x. For Na'aran, see Vincent 1961. For Sepphoris, see Weiss 2005: 105, fig. 46.

61 The two stallions on the left-hand side of the scene are well preserved, while those on the right-hand side are partially damaged. The horses at Sepphoris and $\mathrm{Na}^{\text {c}}$ aran are depicted in profile view and at Beth Alpha in frontal view.

${ }^{62}$ For Sepphoris, see Weiss 2005: 104-10. On zodiac imagery in antiquity, see Gundel 1992. The 3rd-century zodiac mosaic from the Roman villa at Münster-Sarnsheim offers an earlier example of a Helios medallion comparable to Huqoq's (see Parlasca 1959: 86-87, pl. 42). 


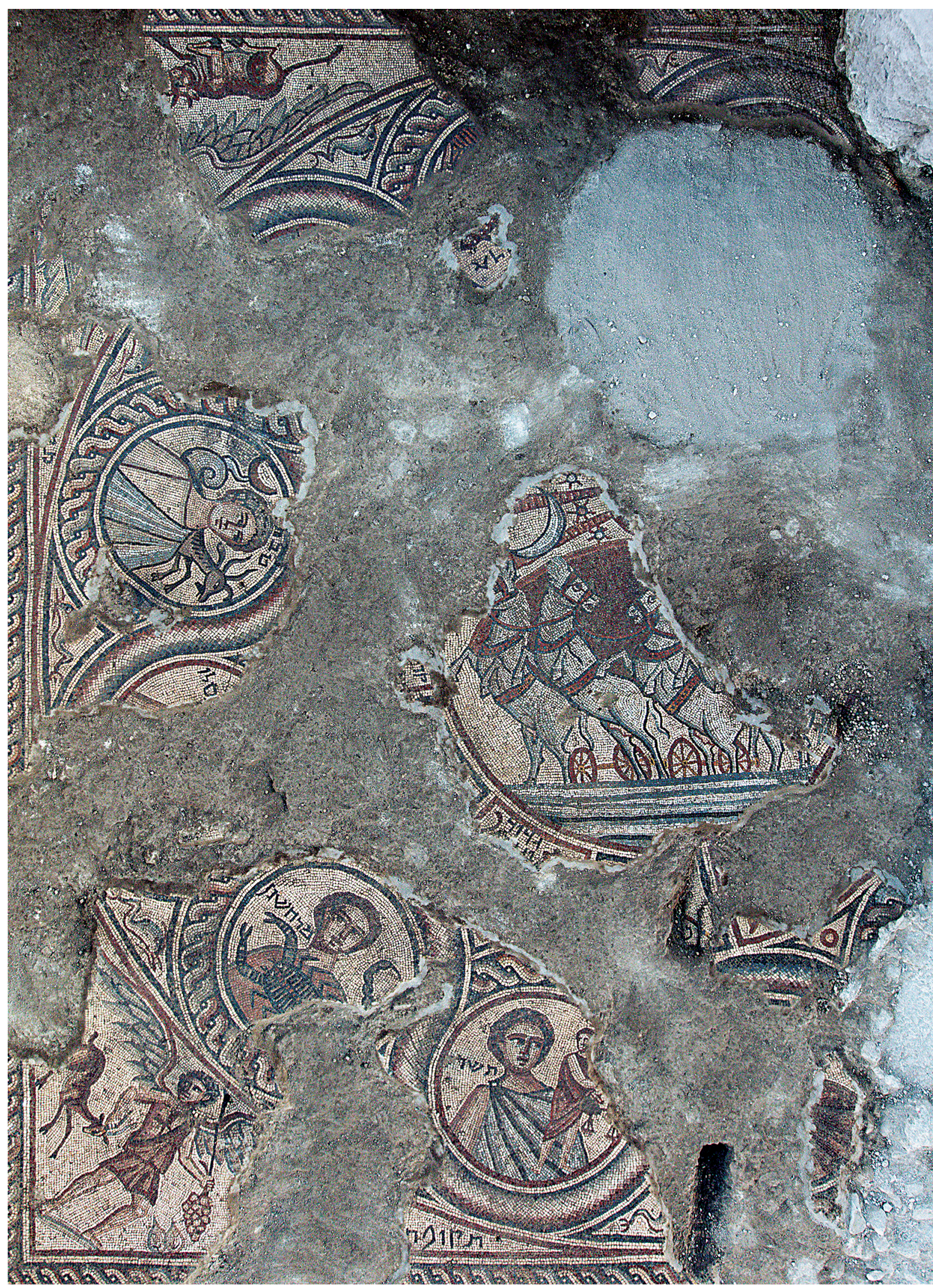

Fig. 41. Synagogue nave: Helios-zodiac cycle. (Photo by J. Haberman; courtesy of the Huqoq Excavation Project) 


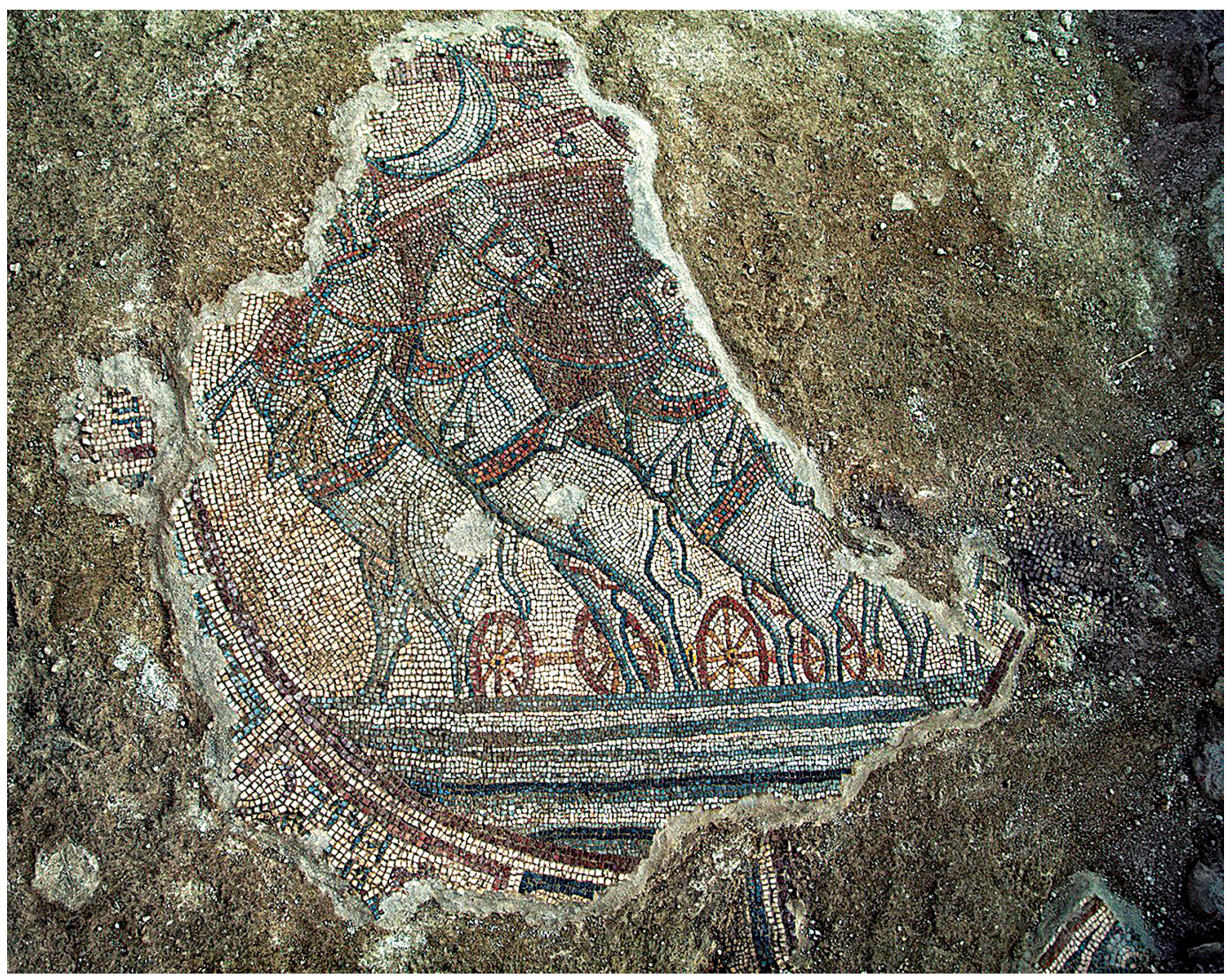

Fig. 42. Synagogue nave: Helios medallion. (Photo by J. Haberman; courtesy of the Huqoq Excavation Project)

and suggests that the partially preserved chariot was depicted, like the stallions, in three-quarters view. ${ }^{63}$

The chariot wheels and stallions stand on a series of uneven horizontal lines of varying thicknesses in shades of gray and black at the bottom of the medallion. A similar, though wavier, set of lines appears in the Helios medallion at Sepphoris, where the horses and wheels are depicted amid the wavy lines rather than on top of them as at Huqoq. ${ }^{64}$ The foreshortened stallions rearing up on their hind legs in front of the chariot create the illusion of foreground and background space; although in keeping with late antique artistic conventions of composition, the illusion of depth is unconvincing. The stallions have rows of black tesserae on their undersides that form a thick outline similar to the fish in the Red Sea panel. Fragmentary inscriptions, perhaps portions of biblical verses from Genesis 49 associated with each

\footnotetext{
${ }^{63}$ In the Helios medallions at Sepphoris, $\mathrm{Na}^{\mathrm{c}}$ aran, and Beth Alpha, the chariots have two wheels and are depicted in frontal view.

${ }^{64}$ Zeev Weiss (2005: 107) identifies the lines as representing a body of water, though it is worth considering the possibility that they represent the celestial firmament instead.
}

of the Twelve Tribes of Israel, are visible in panels encircling the Helios medallion.

Surrounding the medallion were 12 interlacing roundels containing the months and zodiac signs, with single dolphins in the triangular interstices between them. The group of roundels is enclosed within a circular fillet border. The preserved months are personified as cleanshaven young men, labeled in Hebrew and accompanied by the corresponding zodiac symbol. On the west side of the panel, Tevet is depicted with a sea-goat that has the tail of a fish (Capricorn) behind him. ${ }^{65}$ The next roundel below (south) preserves only part of the name of the month Kislev. Below this is the figure of the month of Marheshvan with a large scorpion (Scorpio) in front. The next roundel preserves the figure of Tishrei accompanied by a small human figure holding scales, a personification of Justice (Libra) (Fig. 43).

While we know of only one other synagogue, Sepphoris, that exhibits a combination of personifications of

${ }^{65}$ For similar examples of sea monsters, cf. the sea bull and sea lion in the Hippolytus Hall at Madaba (6th century) (see Piccirillo 1992: 62, fig. 16). 


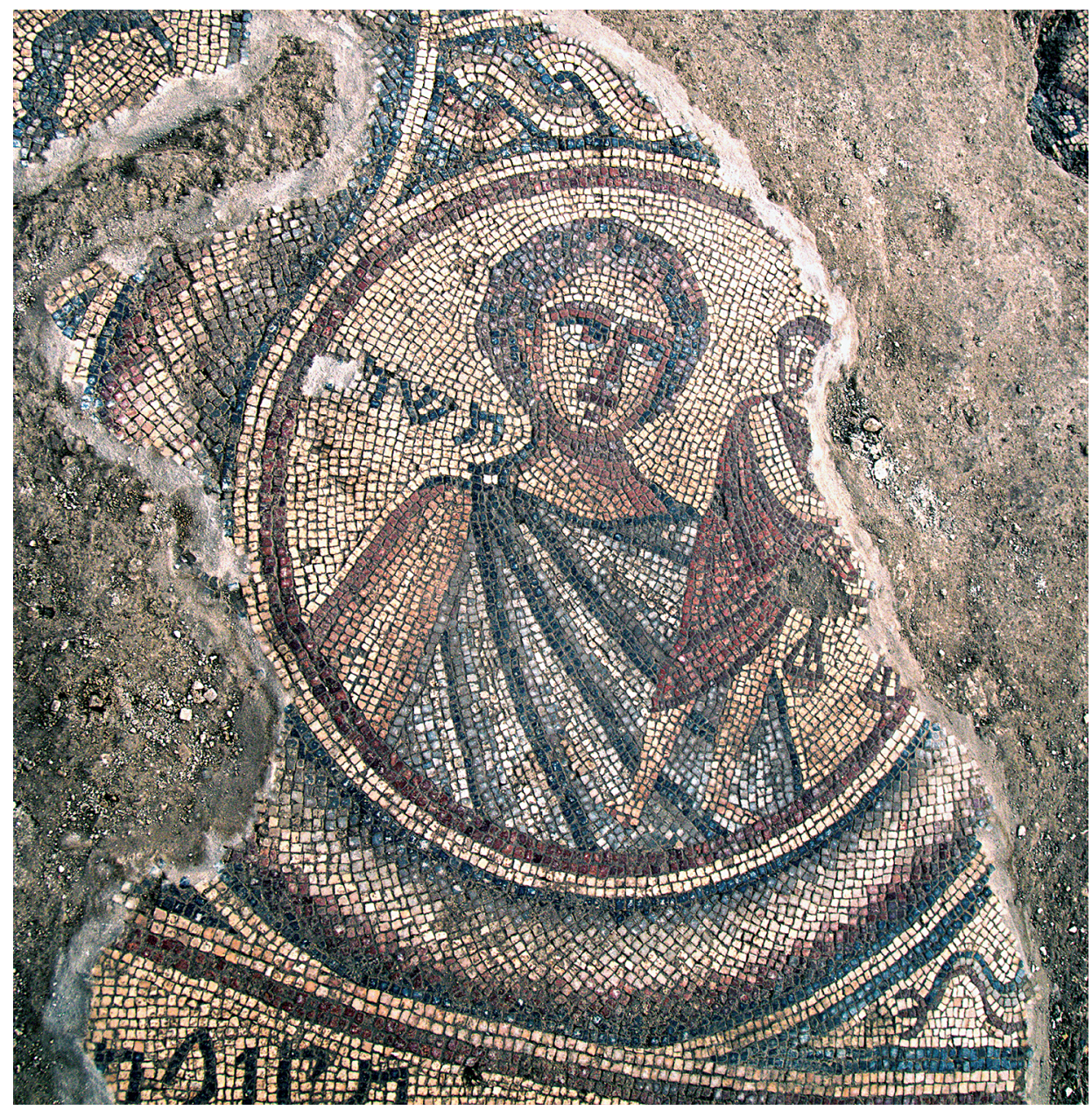

Fig. 43. Synagogue nave: detail of Helios-zodiac cycle showing the month of Tishrei accompanied by the figure of Libra holding scales. (Photo by J. Haberman; courtesy of the Huqoq Excavation Project)

the months, zodiac signs, and inscriptions naming the months, the zodiac cycles at the two sites differ significantly. ${ }^{66}$ Some of the Sepphoris zodiac signs are accompanied by personifications of the months, while others are not (Weiss 2005: 110-23). The personifications of the months at Huqoq are depicted as half-length figures, whereas at Sepphoris, they are represented as full-length figures. At Sepphoris, the name of the sign and the name of the month appear with each zodiac sign.

${ }^{66}$ In all other Helios-zodiac cycles discovered to date, the zodiac signs are depicted without personifications of the months. These mosaics contain only the names of the signs, not the months. The 'Ein Gedi synagogue mosaic has an inscription listing the zodiac signs followed immediately by the Hebrew months and thus appears to be an aniconic variation on the Helios-zodiac cycle. A final excavation report on the

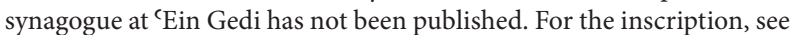
Naveh 1978: 105-9; and Levine 1981.
The interlacing roundels are framed by a large circle set within a square fillet border that delineates the boundaries of the panel. The placement of the circle within the square panel creates triangular spaces (spandrels) in the corners. In the northwest spandrel, the wings of a partially preserved personification of a season are stretched out above a recumbent bull. Only Tishrei (Autumn) in the southwest corner is well preserved (Fig. 44). Tishrei is depicted as a winged male figure holding a bunch of grapes and crook in one hand and grasping the horns of a gazelle in the other, accompanied by two figs. ${ }^{67}$ Tishrei

67 The style of the outspread wing and its placement are similar to the preserved wing in the Helios-zodiac cycle in the Susiya synagogue, which was almost completely destroyed by iconoclasm (see Talgam 2014: 308-10, figs. 379, 380, which, in the absence of a final excavation report, dates the original mosaic floor to the 560s C.E. on the basis of style). 


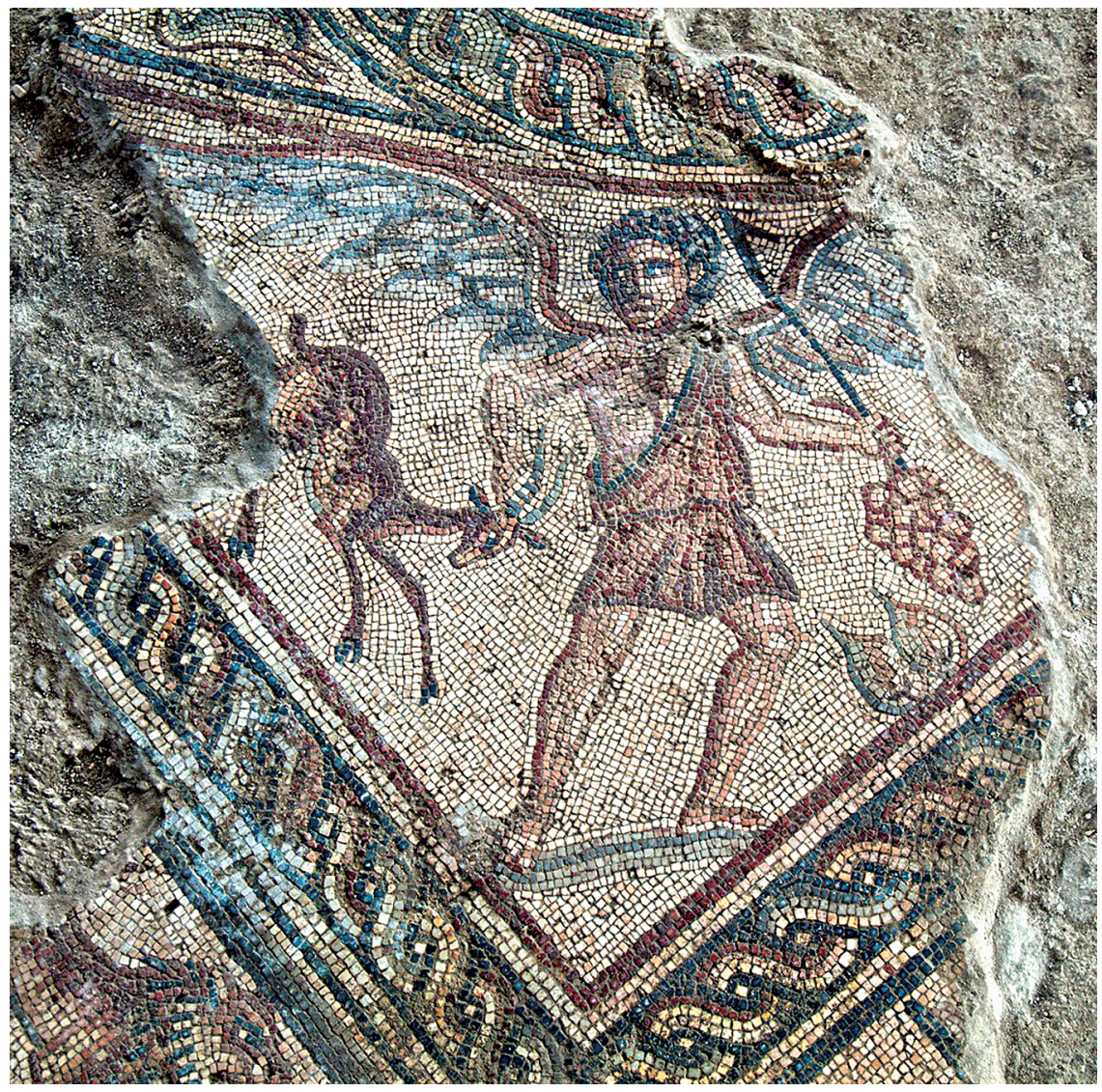

Fig. 44. Synagogue nave: detail of Helios-zodiac cycle showing the autumn season (Tishrei). (Photo by J. Haberman; courtesy of the Huqoq Excavation Project)

wears a short, thigh-length tunic gathered at the waist and tied on one shoulder. The garment, which leaves the chest partially exposed and the arms and legs unencumbered, is generally worn by manual laborers in mosaics. ${ }^{6}$ The depiction of a male season in a synagogue is thus far unparalleled; in the other synagogues with a Helioszodiac cycle, the seasons are female. ${ }^{69}$ While winged seasons are found more commonly in mosaics outside of synagogues, they do appear in the synagogues at Susiya,

\footnotetext{
${ }^{68}$ Similarly clad male figures appear frequently in mosaics of the region, including at Huqoq (the partially uncovered date harvest scene in the west aisle and the Tower of Babel panel in the nave). For a pavement that depicts a wide range of garments worn by agricultural workers and shepherds, see Piccirillo 1992: 153, fig. 202.

${ }^{69}$ Male seasons appear in mosaics in other contexts in this region. For example, busts of male seasons are depicted in the hallway leading to the dining room of the villa at 'Ein Yael near Jerusalem (see Talgam 2014: 46-48, fig. 69) and in the corner roundels of the border of the Mosaic of the Muses and Poets at Gerasa (see Piccirillo 1992: 282-83, fig. 520).
}

Beth Alpha, and possibly Huseifa. ${ }^{70}$ The Hebrew word tequfat ("season of") is preserved to one side.

As noted above, the compositional arrangement of the Helios-zodiac cycle at Huqoq is rare. The only other known example is found in the nave of the synagogue at Yaphi'a, which was poorly preserved at the time of its discovery in the early 1950s by Sukenik (1951: 17-24). We have already mentioned the similarities between the northernmost panels in the nave at Huqoq and the panel at Yaphi'a depicting an eagle standing on a volute-shaped pedestal. In this case as well, the similarities are striking, from the interlacing circles to the dolphins in the interstices. At Yaphica, only two roundels are preserved: one contains a bull and the other a horned animal of which only the head and partial Hebrew inscription remain. Sukenik concluded that the mosaic depicted the 12 tribes

\footnotetext{
${ }^{70}$ For a comparison of the seasons and their attributes in synagogues, see Hachlili 2002: 225-27, fig. 12. For a geographically and chronologically proximate example of winged female seasons from Caesarea Maritima, see Spiro 1990: 31-44.
} 
rather than the zodiac, based on his identification of the horned animal next to the bull as a wild ox representing the tribe of Ephraim. In contrast, Goodenough (19531968 1: 216-18) proposed that the mosaic depicted a zodiac cycle, based on his identification of the animals as a bull and ram, the signs for Taurus and Aries. Gideon Foerster (1987) favors an interpretation that harmonizes the proposals of Sukenik and Goodenough, suggesting that the signs of the zodiac appear in the roundels alongside inscriptions referring to the 12 tribes (see also Talgam 2014: 314-16).

Jonah and the Fish. The panel to the south of the zodiac cycle presents the episode from the story of Jonah in which the prophet, having fled aboard a ship from his divinely appointed mission of announcing the destruction of the city of Nineveh, is cast into the sea by his shipmates (Jonah 1:1-2:1 MT) (Fig. 45). The episode of Jonah and the fish is set within a dense scene of marine and maritime imagery. The placement of the Jonah and the Red Sea panels to the immediate south and north, respectively, of the zodiac cycle establishes what might be described as an "antiphonal" relationship between their themes, iconography, and composition. ${ }^{71}$ The apparent juxtaposition of the Jonah and Red Sea panels is particularly suggestive in light of the multiple connections that Jewish sources from the early medieval period draw between the two narratives. ${ }^{72}$ Both panels depict ferocious fish swallowing human beings in dramatic acts of interspecies hostility. The image of the sea as a place fraught with danger and even violence is further accentuated in the Jonah panel by the central placement-immediately above Jonah and the three fish-of a sea snake wrapped

${ }^{71}$ On the "antiphonal" arrangement of the panels on the west wall of the synagogue at Dura Europos, see Moon 1992: esp. 604-6, which builds on the study of moralizing antitheses in Roman painting in Ling 1979.

72 As elaborated in several early medieval midrashic treatments of the parting of the Red Sea and the story of Jonah, the two biblical narratives share a common set of themes-namely, God's power over the sea, God's use of water as a means of retribution or chastisement, and the recognition of God by gentiles and their repentance and/or conversion. In addition, these sources draw at least three specific narrative connections between the stories (although no single text includes all three): (1) the Egyptian pharaoh is said to have survived the drowning of his army and to have been installed as the king of Nineveh, his firsthand knowledge of the destructive power of God thus explaining his eagerness to repent when confronted by Jonah's message; (2) the sailors invoke the miracle at the Red Sea when imploring Jonah to pray to his God for intervention; and (3) during his time inside the fish, Jonah is taken on a tour of the watery depths and, among other sights, is shown the 12 paths that the Israelite tribes used to cross the Red Sea. For sources and discussions, see Mikva 2012: 185-89; and Feldman 1992: 41. in coils around a long, slender fish with a pointed snout (perhaps a barracuda or swordfish). ${ }^{73}$

The Jonah panel is less chaotic than the Red Sea scene but presents a greater variety of fish and other sea creatures. In addition to almost a dozen distinct species of fish (including perhaps red snapper, sea bass, bream, and mullet), the panel also boasts an octopus with a bulbous head, googly eyes, and stylized wavy tentacles (five of which are visible), and a dolphin with exaggerated, caricatured features. ${ }^{74}$ The Jonah panel also includes vignettes drawn from daily life: a small fishing boat with a man casting a net on the right-hand (east) side, while below the fishing boat two men wearing loincloths are wringing out a fishing net from which water is dripping (only the man on the left is completely preserved).

This impressive variety of marine life and the quotidian activity of fishing frame the dramatic events of the prophet's trial at sea. Prominently represented in the center of the scene is a large sailing ship manned by five sailors, two of whom are climbing the mast. ${ }^{75} \mathrm{~A}$ bearded, partially balding, gray-haired man in the center of the ship-perhaps the captain-is lowering into the water a rope with a loop at the end. Immediately below the rope, Jonah's legs and feet can be seen dangling from the

${ }^{73} \mathrm{Cf}$. the image of a snake wrapped around a similarly shaped fish in the 3rd-century mosaic in the Roman villa at 'Ein Yael (see Talgam 2014: 46-47, fig. 66).

74 The dolphin in the Jonah panel more closely resembles the dolphin in the center of the 4th-century marine scene at Lod (see Talgam 2014: 67, fig. 97) than the more naturalistic depiction of what appears to be a common dolphin (Delphinus delphis) in the 1st- or 2nd-century mosaic in Area H at Tel Dor (see Talgam 2014: 25, fig. 29). For a less stylized depiction of an octopus, see the mosaic fragment from a church uncovered in a monastery in the Kidron Valley (see Talgam 2014: 200, fig. 288).

75 Ships and boats are frequently depicted in mosaics throughout the Roman world, underscoring the significance of the fishing industry for local economies and the Mediterranean Sea for transport and trade (see Marzano 2013). In Galilee, both ships and fishing boats appear in Roman and Byzantine mosaics, thus providing geographical and temporal examples for comparison. The 1st-century mosaic panel from a bath complex in the town of Magdala, located north of Tiberias on the Sea of Galilee, contains a ship with upfurled sails, as at Huqoq; however, the Magdala ship's hull has a different shape and does not have a central mast and rigging (see De Luca and Lena 2014: 12-17). The wellpreserved ship carrying Odysseus in the 5th-century mosaic from the House of Leontis at Beth Shean has a central mast as at Huqoq, but the shape of the hull and upfurled sails is not the same (see Talgam 2014: 376-78). A selected comparison of the Jonah ship with sailing ships in mosaics from the same period (4th-6th centuries) in Palestine but outside the immediate area yields the same general results: some similarities but also some differences (see, e.g., Lod [Haddad and Avissar 2003: 73-77; Friedman 2004: 166-67]; Horvat Beit Loya [Patrich and Tsafrir 1993: pl. XIXa]; and Beit Guvrin [Talgam 2014: 245, fig. 325]). Outside the region, a close parallel for the arrangement of the sails on the central mast of the ship at Huqoq appears in the Great Hunt mosaic (Room 36) at Piazza Armerina, Sicily (Carandini, Ricci, and Vos 1982). 


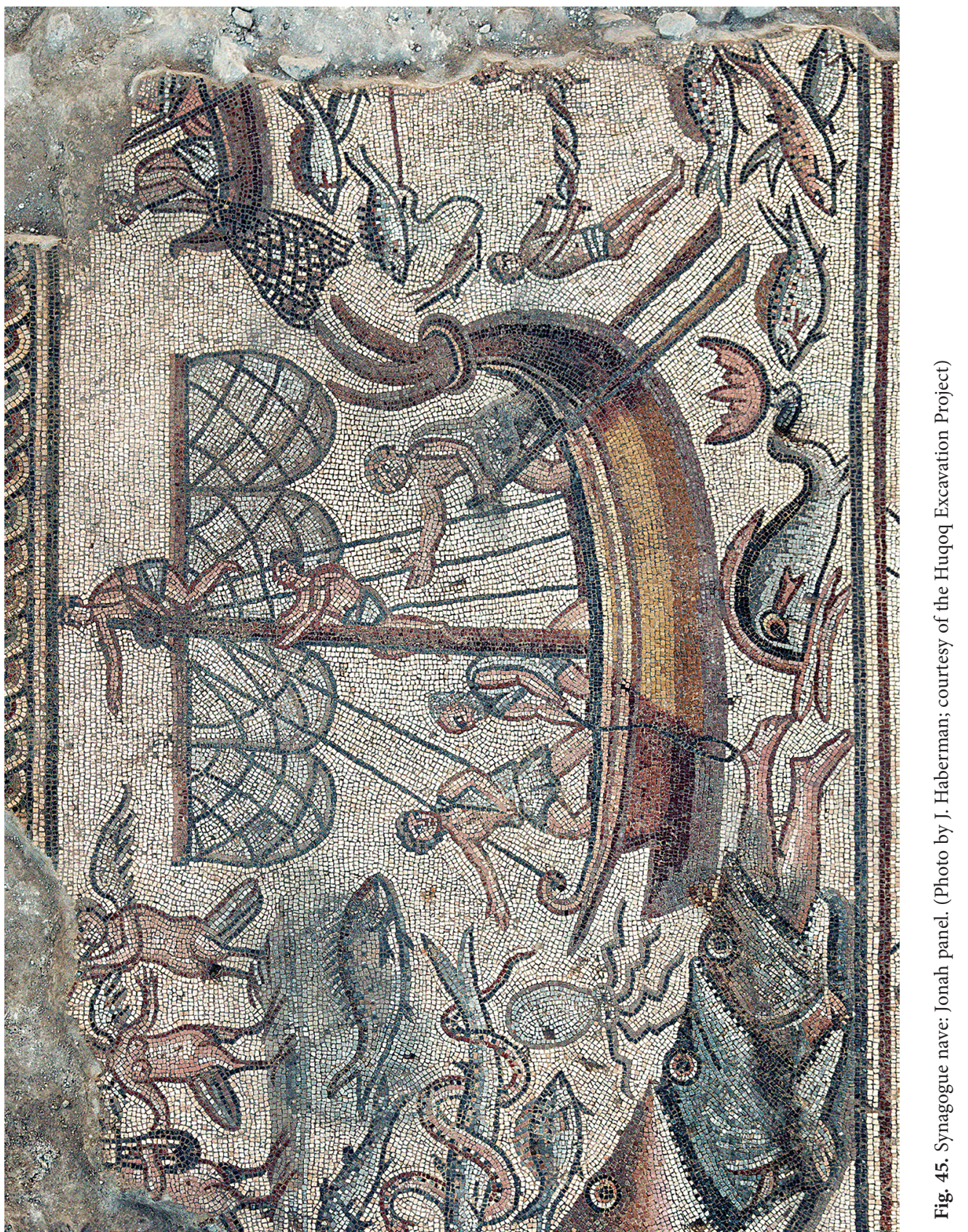




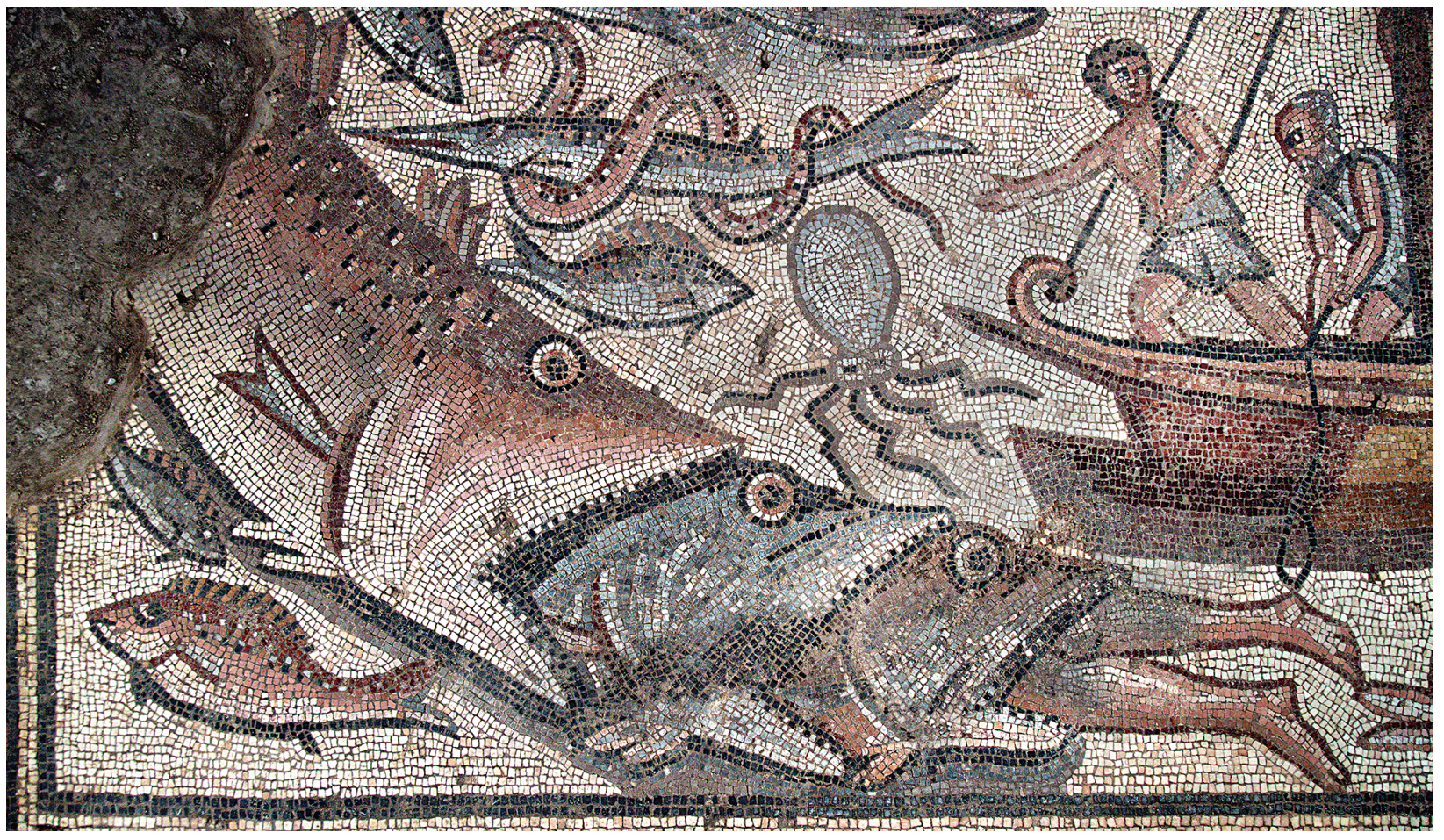

Fig. 46. Synagogue nave: detail of Jonah panel showing the fish swallowing Jonah. (Photo by J. Haberman; courtesy of the Huqoq Excavation Project)

mouth of a large fish, which is being swallowed by two successively larger fish (Fig. 46) ${ }^{76}$ In the sky to the left of the ship, three hybrid creatures-each with the thighs, torso, and head of a woman and the wings, rump, and feet of a bird-stand on a storm cloud (Fig. 47). The trio is dancing and playing musical instruments (a flute and a lyre), attracting the attention of a sailor who points at them from the top of the ship's mast. The combination of their hybrid form, the storm cloud, and the musical performance leaves no doubt that these bird-women are to be identified as harpies or sirens familiar from classical mythology as personifications of storm winds. ${ }^{77}$ Within

${ }^{76}$ A 3rd-4th-century sarcophagus in the Konya Archaeological Museum provides an interesting parallel to the fish swallowing Jonah at Huqoq. On the front of the sarcophagus, a large fish is depicted swallowing Jonah headfirst, and the prophet's torso and legs protrude from the fish's mouth. (For a discussion and illustration, see Dresken-Weiland 1995: pl. 108.) A 5th-century marine mosaic from a bathhouse on the Fundus Bassianus (Sidi Abdullah, Bizerte, Tunis), now in the Bardo Museum, depicts a man being swallowed headfirst by a large fish that has been identified as a dusky grouper (Guidetti and Micheli 2011). The man's legs are shown dangling from the mouth of the fish in a similar manner to Jonah at Huqoq and Konya (Marzano 2013: 248, fig. 38).

${ }^{77}$ In Roman art, harpies and sirens are often indistinguishable due to the conflation of their attributes (see Hofstetter and Krauskopf 1997). On the figure of the siren in classical literature, the Septuagint (especially Isa 13:21-22, 34:13), and ecclesiastical texts and the influence

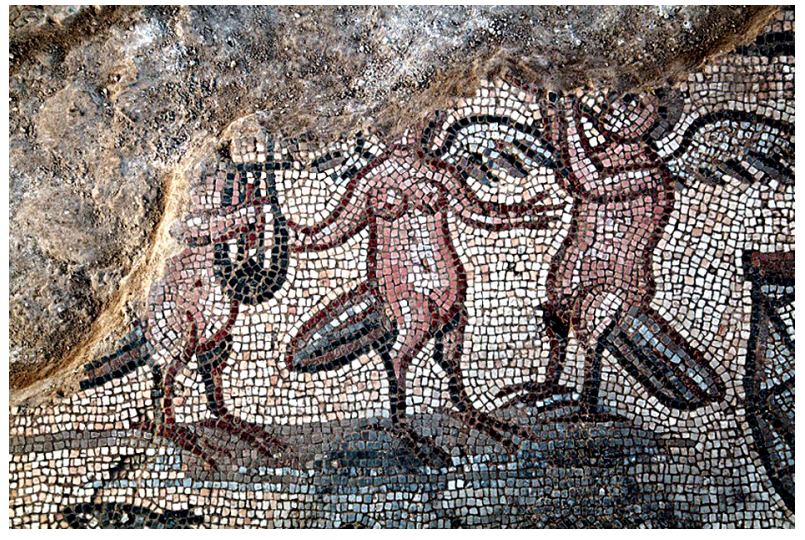

Fig. 47. Synagogue nave: detail of Jonah panel showing the harpies/sirens. (Photo by J. Haberman; courtesy of the Huqoq Excavation Project)

the Jonah panel, these figures represent the storm at sea that God has set in motion to chastise his disobedient prophet and lead him to repent. At the same time, the

of the literary tradition on classical and post-classical visual culture, see Travis 2002. The siren also appears in rabbinic literature at Sifra, Shemini 3:7; Lev Rab. 16.1; Lam Rab. 4:15, although in these sources the creature seems to be part human, part fish, rather than part human, part bird (see Hasan-Rokem 2014). 
scene alludes to Odysseus's famous encounter with the sirens, an episode with a long history of depiction in ancient art (see Touchefeu-Meynier 1992).

A geographically proximate parallel for the birdwomen in the Jonah panel appears in the 5th-century mosaic from the House of Leontis at Beth Shean depicting Odysseus and the sirens (Zori 1966; Talgam 2014: 376-78). In the scene, Odysseus is twice shown in a boat: in the upper right-hand corner, he is tied to the mast by a fishing net to prevent falling prey to the bewitching song of the sirens, while in the lower half of the mosaic he fights a sea monster (Scylla?) from his boat. As in the Jonah panel, a siren playing the flute hovers in the air above the boat, signaling the looming danger. While the House of Leontis siren has the upper body of a woman and the lower body of a bird, the details of her body are rendered differently from the Huqoq figures, which have wings on their backs and the lower torso and thighs of a human.

As the first depiction of the Jonah cycle discovered to date in a specifically Jewish archaeological context, the Huqoq panel is of great significance for the study of both Jewish and Christian art. It may lend some support to scholarly speculation that among the many depictions of Jonah in a variety of media from late antiquity are artifacts that were produced by or for Jews. ${ }^{78}$ Similarly, the discovery of the Jonah panel at Huqoq may bolster the identification of fragmentarily preserved images of fish at other synagogues as belonging to the Jonah cycle. ${ }^{79}$ Moreover, the depiction of Jonah being swallowed by a succession of three fish has its closest parallels in a cluster of Jewish and Islamic sources from the early medieval period. ${ }^{80}$ The panel may contain a visual expression of an exegetical (rabbinic?) motif that was in general circulation among Jews centuries earlier but was preserved in the textual tradition only at a considerably later stage.

The Huqoq panel may also have implications for the possible connection that we drew above (in the section on Noah's ark) between the Huqoq synagogue and the building at Mopsuestia, which receives additional sup-

78 See, most recently, Gregg 2015: 361-67, in which the author discusses images of Jonah on otherwise religiously neutral items, such as a gold glass from Rome (fig. 10.2) and an incised gem (fig. 10.3).

${ }^{79}$ See, e.g., Vitto 2014, in which the author proposes that a large fish (measuring no less than $75 \mathrm{~cm}$ ) drawn on a fragment of plaster from the walls of the 5th- or 6th-century synagogue at Rehov derives from a scene depicting Jonah and the fish.

${ }^{80}$ For the motif of the three fish, see especially "The Midrash of the Repentance of Jonah the Prophet," published in Kadari 2002: 73; and the version of "Midrash Jonah" in Jellinek 1967 2: 99, which may make oblique reference to this tradition. For comparative analysis of the Jewish and Islamic sources, see Kadari 2016. Interestingly, as Tamar Kadari notes (p. 115), it is only in the Islamic sources that the three fish swallow each other with Jonah still inside the first one, while the Midrash relates that three fish each swallowed Jonah and spat him out successively. port when we consider other similarities between their mosaics. The excavator of the building at Mopsuestia suggested that a fish found in a fragmentary panel in the nave belongs to a depiction of the story of Jonah, which he in turn invoked as evidence to support his identification of the building at Mopsuestia as a church. ${ }^{81}$ The story of Jonah was also depicted in an elaborate series of mosaic panels in the aisles of the 6th-century church of Mahatt el-Urdi near Beit Guvrin (Eleutheropolis) in Palestine. ${ }^{82}$

In addition to the Noah's ark and, possibly, Jonah panels in the nave, the north aisle of the Mopsuestia building boasted an elaborate Samson cycle that included as many as 11 scenes from the book of Judges (especially 14:616:30). In these scenes, Samson is depicted as a giant. While the scenes survive in poorly preserved fragments, the accompanying inscriptions are in a better state of preservation and assist in the identification and reconstruction of the continuous narrative. ${ }^{83}$ The presence of an elaborate Samson cycle in the aisle-in conjunction with the Noah and, possibly, Jonah panels in the navefurther strengthens the intriguing affinities between the synagogue at Huqoq and the building at Mopsuestia, and may add weight to the suggestion by Avi-Yonah (1981: 189-90) that the latter was, in fact, a synagogue.

While the iconography chosen for the mosaics in the Huqoq synagogue connects it to the artistic repertoire drawn upon by Jewish and Christian communities far beyond Galilee, the discovery of two Samson scenes in Huqoq's southeast aisle also links it firmly to its immediate surroundings in the eastern Lower Galilee. ${ }^{84}$ The synagogue at Wadi Hamam likewise included in its aisle (west) a mosaic pavement depicting Samson-in this case, the episode from Judg 15:15-17 where he strikes down the Philistines with the jawbone of an ass (Leibner and Miller 2010: 252-56). As at Huqoq, Samson wears Roman military dress and is monumental in size; he towers over his Philistine enemies whom he has killed or wounded. As Leibner and Miller (2010: 256) have observed, while Samson is not described as a giant in the Hebrew Bible, he is portrayed as such in some rabbinic texts, perhaps as a reflection of his immense physical

\footnotetext{
${ }^{81}$ Ludwig Budde (1969: 85-87) cites the Jonah cycle in the early 4 th-century mosaic floor in the basilica at Aquileia as a possible parallel. For Aquileia, see Engemann 1997: 55-59.

82 The church was discovered in 1941-1942 and was published in Baramki 1972 (see also Ovadiah 1974; Foerster 1978: 289-94; and, more recently, Talgam 2014: 244-46, in which the author dates the mosaic to the mid-6th century based on style).

${ }^{83}$ Avi-Yonah (1981: 188) and Kitzinger (1973: 144, n. 51) agree that the inscriptions follow the B (Codex Vaticanus) version of the Septuagint.

${ }^{84}$ On Samson as a redeemer figure in the regional culture of late antique Galilee, see Grey 2013; and Magness 2013: 66-67.
} 
strength and his status as a messianic warrior-redeemer (see also Fogel 2009: 89-130; and Grey 2013).

Thus, we have the depiction of Samson as a giant in three mosaic pavements from the same period: two located in the eastern Lower Galilee-both securely identified as synagogues-and one in Cilicia. The Huqoq synagogue and the building at Mopsuestia are the only known examples where this combination of subject matter-Noah, Jonah, and Samson-occurs, suggesting that the mosaic programs of some synagogues in Palestine were informed by and participated in macro-regional trends.

Tower of Babel. The panel to the south of the Jonah scene depicts the construction of the Tower of Babel (Gen 11:1-9) and God's punishment of the people for building a tower intended to reach to heaven (Fig. 48). Just as the Jonah and Red Sea panels form an iconographic and thematic pair, the Tower of Babel panel in the southern end of the nave and the Noah's ark panel at its northern end may echo each other antiphonally. ${ }^{85}$ The chaos and violence that unfold throughout the panel serve as graphic depictions of the punishment that God exacted from the builders for their act of hubris. In this scene, the workmen are differentiated by hairstyles and facial hair, clothing, and even skin color in an attempt to portray different peoples. ${ }^{86}$ Amid the ongoing work, divine punishment for constructing the tower is represented by the deaths of some of the workmen who are shown falling headlong from the scaffolding and the ropes of the pulley as well as by a violent fight between workmen.

At the center of the scene, a square tower is in the process of being built by workmen carrying the ashlars used in its construction. ${ }^{87}$ On the top of the tower, a pair

85 There are many affinities between the two narratives. Both derive from the "primeval history" (Gen 1-11), and, indeed, Noah is said to have lived through the dispersion of the "generation of Babel"; both feature elaborate building projects that result in the creation of unique structures (even if one is the cause of catastrophe and the other the remedy to it); and, most importantly, both center on the chastisement of a sinful humanity prior to the birth of Abraham and the people of Israel. For connections between the narratives in Jewish and Christian traditions, consult Ginzberg 1998 1: 174-81 (narrative); 1998 5: 201-2 (sources and discussion) (see also Feldman 1999-2000).

86 The notion that God punished humanity for attempting to build the tower by introducing not only linguistic diversity but ethnic differentiation by skin color already appears in the 1st or 2nd century (Pseudo-Philo, Lib. Ant. Bibl. 7.5). For discussions, see Goldenberg 2003: 98-99; and Jacobson 1996: 384.

87 The use of stones rather than clay bricks is noteworthy. According to the biblical account (Gen 11:1-9), the tower was constructed from clay bricks (Gen 11:3), which were in fact the dominant building material in the city of Babylon (Finkel 2014: 235-39). But in some midrashic sources, the clause "they had brick for stone and bitumen for mortar" (Gen 11:3) is interpreted to suggest that the project proceeded of workers is depicted carrying a large stone block, while another worker lowers an indeterminate round object suspended from a rope over the left side of the tower. A wooden parapet wraps around the tower at its midpoint. A partially preserved worker is depicted straddling the parapet. Beneath the parapet, a portion of the lower tower is obscured by an installation of real ashlars that postdates the mosaic (possibly the remains of a bema). At the bottom of the tower, a worker carrying an ashlar on his back climbs three steps to the tower doorway. Adjacent to the right side of the tower is a wooden scaffolding structure, preserved only in fragments due to damage to the east side of the panel. It is clear from the placement of the dark-skinned worker sliding down the scaffolding that the structure originally reached to the top of the tower. Below the dark-skinned figure, another worker falls headlong from the tower or the scaffolding. Beneath the falling figure, a third worker carrying a jar on his left shoulder appears to be standing on the scaffolding ramp. At the base of the tower, two figures are strapping a large ashlar to the back of a crouching workman.

An elaborate pulley system used for the movement of construction materials stands to the left of the tower and is operated by manpower: four men are shown turning a winch. On the opposite side, a worker stands on the stepped base of the tower and pulls on a pulley rope. Another worker (only legs and feet are preserved) stands on an ashlar suspended in mid-air as it is being raised by the pulley. Across the top left side of the panel, ropes extending from the pulley are cut off by the panel's border. Two workers are depicted in acrobatic positions as they maintain their balance on the ropes, while a third figure holding a window (?) falls headlong to the ground.

To the left side of the pulley are vignettes depicting activities related to the construction of the tower, including quarrying stone and sawing, planing, and chiseling wood; each vignette is placed on a separate ground line. A worker is shown quarrying stones with a pick, which are depicted as ashlar blocks to make clear to the viewer what work is being performed. To the right of the quarrying, a worker loads the blocks onto a reclining camel for transport. Below, a pair of figures using a two-person saw split a piece of wood held in a large wooden vise. To the right, a light-skinned worker and a dark-skinned one engage in a fight. The dark-skinned figure holds an ax (or mallet) in his raised right hand as he grasps the throat of the light-skinned figure with his left hand (Fig. 49). In turn, the light-skinned figure grabs the dark-skinned figure by the arm with his left hand and holds a bow saw

especially rapidly and the bricks hardened into stone (see, e.g., Gen Rab. 38:3). 


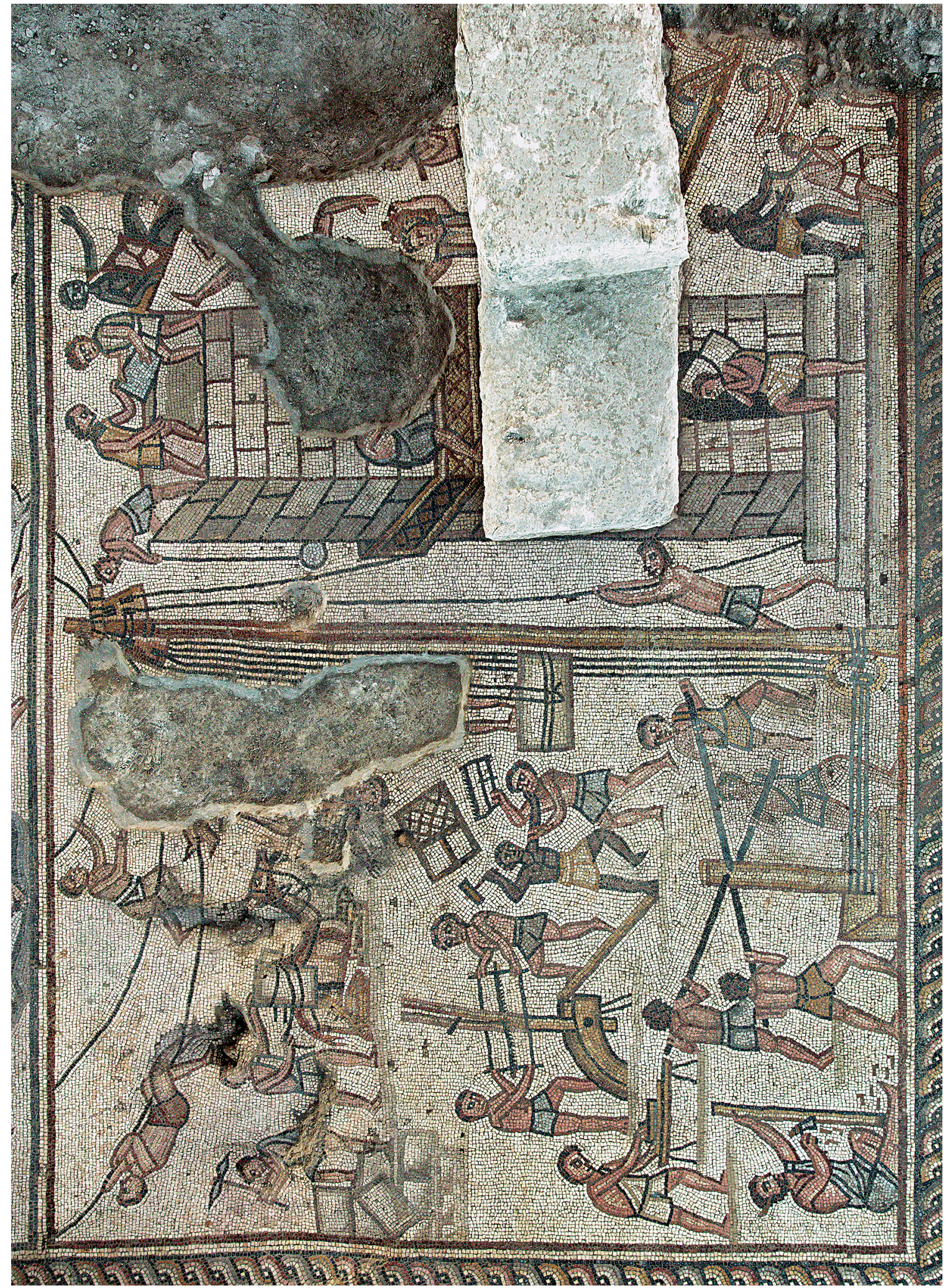

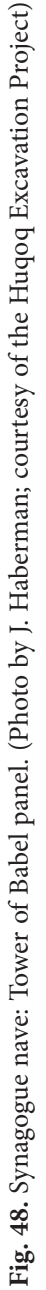




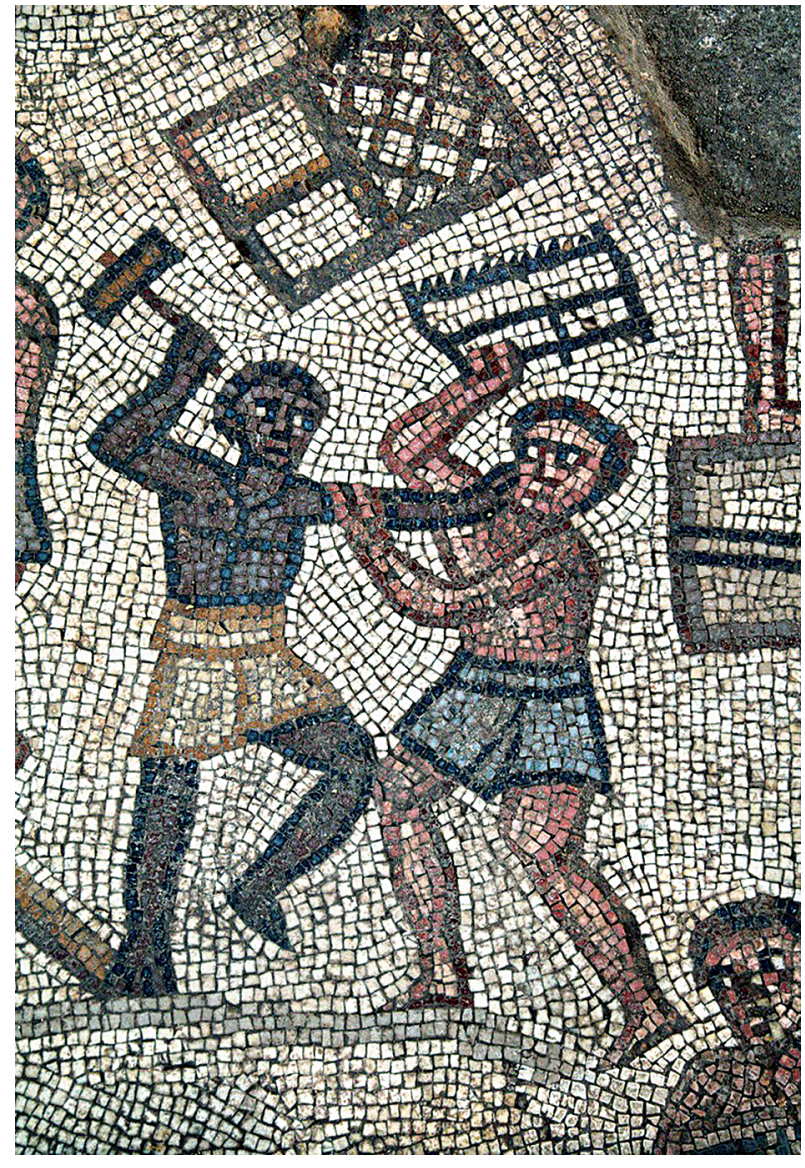

Fig. 49. Synagogue nave: detail of Tower of Babel panel showing workmen fighting. (Photo by J. Haberman; courtesy of the Huqoq Excavation Project)

in his raised right hand ${ }^{88}$ A nearby worker uses a hand plane to shape wood that has been laid on sawhorses. In the bottom left corner of the panel, a bearded worker is seated on the border, which doubles here as a ground line. He appears to have an object (tool?) tucked behind his right ear. His left leg is bent at the knee, and his right leg is extended in front of the piece of wood that he smooths with a tool (adze) as the shavings fall to the ground.

The only known example of a Tower of Babel scene that resembles Huqoq's occurs in the nearby synagogue at Wadi Hamam, lending further support to the previously suggested notion of a localized repertoire of shared

${ }^{88}$ According to Gen Rab. 38:10, the proliferation of languages caused by God led the builders of the tower to miscommunicate regarding the specific tools that one requested from another, thereby leading to violence; just as in the Huqoq panel, the workers wound each other with their tools. For a discussion of this tradition in the context of the Tower of Babel panel at Wadi Hamam, see Leibner and Miller 2010: 247, n. 56. themes (see Leibner and Miller 2010: 241-49, color fig. A on p. 253). The preserved portions of the Wadi Hamam scene depict individual and small groups of workmen engaged in many of the same construction tasks represented in the Huqoq mosaic. The similarities extend to a vignette showing a fight between two workmen who hold the same tools in both mosaics. A notable difference, however, is the shape of the towers: square at Huqoq and polygonal at Wadi Hamam. In their interpretation of the mosaic, Leibner and Miller discuss a number of large-scale construction projects in the Hebrew Bible, including the Tower of Babel, but ultimately favor an identification of their scene as depicting the construction of the Jerusalem temple (2010: 246-49). The Huqoq mosaic now permits a secure identification of the scene at Wadi Hamam as the Tower of Babel. The construction of the Tower of Babel is also depicted in medieval illuminated manuscripts. ${ }^{89}$

\section{Preliminary Observations about the Huqoq Mosaics}

A number of general thematic patterns have begun to emerge in the mosaics of the Huqoq synagogue. Particularly prominent among those present in the panels thus far uncovered are leitmotifs of water and the violent destruction of life, whether human or animal. The awesome power of water is a recurrent element in the nave panels depicting Noah's ark before the flood, pharaoh's army drowning in the Red Sea, and Jonah swallowed by fish amid a storm at sea. Even the zodiac cycle, which lies at the center of this sequence of scenes, employs marine imagery in the series of dolphins along the border. The theme of crisis and potential destruction in the nave mosaics resonates with the emphasis on conflict with foreign powers in the panels of the east aisle: the drowning of the Egyptian soldiers complements the scenes of military conflict with the Philistines and the Greeks found in the east aisle. The Tower of Babel panel likewise dramatizes the violent aftereffects of sin or hubris for a linguistically and ethnically fractured humanity. At the same time, the elephant panel may show as much interest in the potential for concord between Jews and their gentile rulers as in celebrating Jewish military heroism. This constellation of narrative traditions-each with its own distinctive take on the interrelated but distinct themes of human moral failure, Jewish-gentile relations, ecological crisis, military conflict, and divine deliverance-is reminiscent of Jewish penitential prayers from late antiquity, which appeal to God for assistance at times of communal

${ }^{89}$ The best known of the medieval miniatures comes from the early 15th-century Bedford Book of Hours, f. 17v (British Library). 
need by invoking these and other biblical and historical precedents. ${ }^{90}$

Taken together, the panels uncovered to date at Huqoq, which exhibit numerous interconnections with one another and with broader iconographic and textual traditions, have the same quality of "copious chaos" that Annabel Wharton (1994: 15; 1995: 43) has identified in the cycle of frescoes in the Dura Europos synagogue. Moreover, the Huqoq mosaics suggest that there was greater flexibility in the choice of subjects and their thematic arrangement within synagogue buildings than previously believed. They challenge many of the conventional scholarly assumptions regarding synagogue mosaics, especially in their relative uniformity and circumscribed range of imagery. Most notably, the Huqoq mosaics overturn the standard view that synagogue mosaics do not contain representations of "historical" narratives or scenes from daily life. Moreover, they call into question the extent to which a monolithic set of programmatic principles guided the production of synagogue mosaics or shaped the viewing experience of synagogue-goers. At least in the case of the Huqoq synagogue, the mosaic pavements uncovered thus far do not so much give expression to a coherent ideology or convey a unitary message as bring into productive dialogue a collection of scenes that share overlapping imagery and mutually reinforcing themes.

At the same time, the Huqoq mosaics suggest that certain themes were of particular interest to synagogue communities in the eastern Lower Galilee. The mosaics in general-and especially the commemorative panel, the elephant panel, and the Jonah panel-make conspicuous use of iconographic elements and visual formulae for representation drawn from the repertoire of classical art as well as figures from classical myth and history. As a group, the mosaics raise intriguing and important questions about the relationship of the Huqoq community to its immediate neighbors and, in particular, the synagogue at Wadi Hamam, where the similarities of the programs in terms of subject matter as well as style indicate production by the same workshop. At the same time, the Huqoq mosaics reveal connections to the wider

\footnotetext{
${ }^{90}$ In light of the centrality of water in the Huqoq mosaics, it might also be significant that the tradition of Jewish penitential prayer from late antiquity was closely related to-and may even have emerged from-practices of communal fasting undertaken in response to drought, especially as prescribed in $\mathrm{m}$. Ta'anit $2: 1-4$. It is significant that the Mishnah has here adapted a preexisting set of liturgical practices to rabbinic specifications (Naeh 2006: 53-56), suggesting that these types of penitential litanies were in circulation beyond the bounds of the rabbinic movement in Roman Palestine from at least the 2nd century C.E. On the history of Jewish penitential prayers in late antiquity and the poetics of their litany form, see Lieber 2008.
}

Galilee (Yaph'ia, Sepphoris) in certain features of their composition, iconography, and style.

However, the local and regional dimensions do not fully account for the subject matter and iconography of the Huqoq mosaics. They also possess surprising affinities with mosaics in religious and non-religious buildings from the wider Mediterranean. This juxtaposition of local idiosyncrasy, regional trends, and interregional connections has important implications for our understanding of the Galilee in late antiquity. The evidence emerging from this region challenges notions of a single center of mosaic production and, by extension, the view that towns and villages in Galilee were heavily dependent on cities such as Sepphoris for the creation of sophisticated and even innovative artistic projects. In addition to their engagement at local levels, villages like Huqoq and Wadi Hamam seem to have participated in robust transregional networks of cultural production that generated connections to other centers, such as Antioch. Such contacts might explain the remarkable similarities found in the 5th-century mosaic programs of a building in Cilicia and a synagogue in the eastern Lower Galilee.

\section{Jewish Settlement and Galilean-Type Synagogues in Light of the Huqoq Discoveries}

The Huqoq excavations have brought to light sturdy village houses filled with evidence of agricultural activity. These houses, which were constructed in the early 5 th century and were occupied for nearly 200 years, provide evidence of a flourishing Jewish settlement during a period of supposed decline. A high level of prosperity is indicated by the monumental, richly decorated synagogue building, which was constructed around the same time as the excavated village houses. The dating of the Huqoq synagogue to the early 5 th century does not by itself prove that all Galilean-type synagogues are later than the 2nd to 3rd centuries, but it does mean that Galileantype synagogues cannot be assigned an earlier date automatically based on stylistic considerations alone.

Approximately $8 \mathrm{~km}$ south of Huqoq, the 2007-2012 excavations at Khirbet Wadi Hamam, directed by Leibner and assisted by Benjamin Arubas on behalf of The Hebrew University of Jerusalem, brought to light a Galilean-type synagogue measuring ca. $17 \times 14 \mathrm{~m} .{ }^{.1}$ The

\footnotetext{
${ }^{91}$ For the synagogue at Khirbet Wadi Hamam, see Leibner 2010; Leibner and Miller 2010; and Leibner and Arubas 2015: 34-39. For a critique of the dating, see Magness 2012. Leibner's dating of the Wadi Hamam Phase II synagogue to ca. 300 C.E. would mean its mosaics were laid over a century earlier than those at Huqoq. We believe Magness's proposed late 4th-century date for the Wadi Hamam Phase II synagogue, which is based on an evaluation of the published ceramic and numismatic evidence, makes more sense in light of the strong parallels with the Huqoq mosaics.
} 
excavators have distinguished two successive synagogue buildings (Phases I, II), the construction of which they date to the early 3 rd century and the late 3rd to early 4 th centuries C.E., respectively. The Phase II synagogue was paved with a mosaic floor that survives in a highly fragmentary condition. Nonetheless, it is clear that the aisles were decorated with 10 or 12 panels containing figural scenes, of which parts belonging to four panels are preserved. As noted above, the striking similarities between the Huqoq and Wadi Hamam mosaics in style and content suggest production by the same workshop.

The synagogues at Wadi Hamam and Huqoq join Horvat 'Ammudim (excavated by Lee I. Levine in 1979) and the intermediate phase at Arbel in forming a subgroup of Galilean-type synagogues paved with mosaic floors instead of flagstones, all located in the eastern Lower Galilee..$^{92}$ This subgroup differs from synagogues paved with mosaics that are not of the Galilean type (e.g., Sepphoris, Hammath Tiberias, Beth Alpha) in having figural scenes in the aisles as well as in the nave..$^{93}$ They also differ in not labeling the figures in the mosaic panels (except in the Helios-zodiac cycle). It is possible that other Galilean-type synagogues had mosaic floors-for example, at Gush Halav, where numerous tesserae found in fills led the excavators to conclude that there may have been a mosaic floor "at some point in the building's history." To the subgroup of Galilean-type synagogues paved with mosaics, we may add the synagogue at Meroth in the Upper Galilee, which the excavators date to the late 4th or early 5th century and which originally had a plaster floor (see Ilan 1993; 1995). Interestingly, the excavators mention that the walls were plastered and painted in red and yellow. In the second half of the 5th century, a mosaic pavement was laid, which includes a panel at the

\footnotetext{
${ }^{92}$ For Horvat 'Ammudim, see Levine 1993. For Arbel, see Ilan and Izdarechet 1993.

93 Talgam's list of "Galilean synagogues" with mosaics (2018: 2-3, n. 6) includes synagogues that are not of the Galilean type (e.g., Horvat Kur, Hammath Tiberias).

${ }^{94}$ See Meyers, Meyers, and Strange 1990: 79, in which the authors claim, however, that the small number of tesserae argues against the possibility of a mosaic floor.
}

north end of the east aisle depicting a young warrior surrounded by a sword, bronze helmet, and oval shield that scholars have identified as David. ${ }^{95}$

The Huqoq synagogue displays numerous anomalies in layout and decoration. The floor in the nave is $0.20 \mathrm{~m}$ lower than the aisles, an arrangement unparalleled in other late antique synagogues. ${ }^{96}$ Unlike in most other ancient synagogues, there are no remains of benches at Huqoq, nor were any planned, judging from the arrangement of mosaic panels in the aisles. ${ }^{97}$ Perhaps the small step created by the height differential between the aisles and the nave was used for seating. The Huqoq synagogue has also yielded a rare example of a freestanding 3D marble menorah from northern Palestine. The Huqoq mosaics include the first non-biblical story ever discovered decorating an ancient synagogue (the elephant panel) and, perhaps, the first scene of everyday life. The imagery surrounding the inscription in the commemorative panel is unique in synagogue art. Likewise, the biblical scenes depicted at Huqoq are rare or unattested in other ancient synagogues.

To conclude, the Huqoq excavations provide evidence of a rural Jewish community in the eastern Lower Galilee that flourished in the 5th and 6th centuries C.E. and constructed a monumental Galilean-type synagogue, decorated with figural mosaic floors, colorful painted and molded plaster, and carved architectural elements. If the medieval public building at Huqoq is a synagogue, it is no less important than its predecessor, as virtually nothing is known about Jewish settlement in Galilee during the 12th and 13th centuries. Finally, the excavations reveal the development of the village of Yakuk in the Late Ottoman period and shed light on the events of 1948, which brought to an end the long history of settlement at the site.

\footnotetext{
${ }^{95}$ For a recent discussion of this panel, see Talgam 2014: 323-26. In a forthcoming article, Magness proposes identifying this figure as Samson.

96 This arrangement is reminiscent of some pre-70 C.E. synagogues, such as Magdala (Migdal) (see Avshalom-Gorni and Najar 2013).

97 There are also no benches in the Sepphoris synagogue (see Weiss 2005: 18-29).
}

\section{Appendix A: Pottery Catalog (Figs. 4, 7)}

\section{Daniel Schindler}

\section{Area 2000 (Ancient Village)}

No. 1: Bowl (Fig. 4:1 [scale 2:5])

Find Context: Locus 2073, Basket 20674\26 (2012)

Preservation: One sherd preserving most of the vessel profile; est. $0.17 \%$ diameter preserved.
Measurements: Est. diameter: $28 \mathrm{~cm}$

Clay: 7.5R 4/1; exterior and interior margins: 7.5R 4/4

Description: Fine-grained ware with a reddish-gray core and reddish-purple exterior and interior margins; rouletting on exterior of rim; many small white inclusions. Comparison: Hayes 1972: 329-38, PRS ("LRC") form 3F 
No. 2: Bowl (Fig. 4:2 [scale 2:5])

Find Context: Locus 2071, Basket $20525 \backslash 3$ (2012)

Preservation: One sherd preserving the rim; est. 0.07\% diameter preserved.

Measurements: Est. diameter: $28 \mathrm{~cm}$

Clay: 10R 5/6

Description: Very fine-grained reddish-orange ware; exterior and interior surfaces coated in red self-slip (7.5R 5/8); many small white and black grits.

Comparison: Hayes 1972: 329-38, PRS (“LRC”) form 3H

No. 3: Bowl (Fig. 4:3 [scale 2:5])

Find Context: Locus 2191, Basket $21513 \backslash 4$ (2014)

Preservation: One sherd preserving the rim; est. $0.11 \%$ diameter preserved.

Measurements: Est. diameter: $27 \mathrm{~cm}$

Clay: 2.5YR 5/6

Description: Fine-grained reddish-brown ware; some small white and black grits; occasional medium red grits; occasional medium-to-large white and black grits.

Comparison: Adan-Bayewitz 1993: 103-9, Galilean bowls form $1 \mathrm{E}$

No. 4: Casserole (Fig. 4:4 [scale 2:5])

Find Context: Locus 2073, Basket 20674\35-45 (2012)

Preservation: 11 sherds preserving the rim, handle, and most of the vessel profile; est. $0.30 \%$ diameter preserved.

Measurements: Est. diameter: $29 \mathrm{~cm}$

Clay: 2.5YR 3/3

Description: Sandy dark reddish-brown ware; some small white and stone grits.

Comparison: Schindler 2017: 189-91, casserole form 2A

No. 5: Cooking pot (Fig. 4:5 [scale 2:5])

Find Context: Locus 2184, Basket 21471\16 (2014)

Preservation: One sherd preserving the rim, additional sherds preserving a large part of the vessel profile; est. $0.18 \%$ diameter preserved.

Measurements: Est. diameter: $10.5 \mathrm{~cm}$

Clay: 2.5YR 5/6

Description: Sandy reddish-brown ware; some small-tomedium white and black grits; some small-to-medium quartz inclusions.

Comparison: Schindler 2017: 199-200, cooking pot form $2 \mathrm{~B}$

No. 6: Storage jar (Fig. 4:6 [scale 2:5])

Find Context: Locus 2142, Basket $21165 \backslash 3$ (2013)

Preservation: One complete rim and neck to the join with the shoulder.

Measurements: Diameter: $7 \mathrm{~cm}$

Clay: 10R 4/4

Description: Coarse red ware with a dark gray core where present; some medium stony inclusions.
Comparison: Schindler 2017:212-14, storage jar form 6A

No. 7: Juglet (Fig. 4:7 [scale 2:5])

Find Context: Locus 2111, Basket 20909\1-20 (2013)

Preservation: 20 sherds preserving roughly two-thirds of the entire vessel and the complete profile.

Measurements: Diameter: $3 \mathrm{~cm}$

Clay: 2.5YR 6/6

Description: Hard-fired light red ware; shoulder decorated with burnished gouged lines; many small black grits, occasional medium white and black grits.

Comparison: Magness 1993: 241, FBW juglet form 2B (nos. 1, 2)

No. 8: Oil lamp (Fig. 4:8 [scale 1:2])

Find Context: Locus 2039, Basket 20362\1-6 (2012)

Preservation: Six sherds preserving the entire vessel.

Measurements: Est. length: $9.5 \mathrm{~cm}$; est. width: $7.1 \mathrm{~cm}$

Clay: 5YR 7/4

Description: Fine, well-levigated pink ware; exterior surface has traces of red slip (10R 6/6); exterior surface has molded decoration.

Comparison: Schindler 2017: 232-34, lamp form 4B

\section{Area 3000, Stratum 2}

\section{No. 1: Bowl (Fig. 7:1 [scale 2:5])}

Find Context: Locus 3122, Basket 30967\2 (2013)

Preservation: One sherd preserving the rim.

Measurements: Est. diameter: $22 \mathrm{~cm}$

Clay: 10R 4/4

Description: Sandy reddish-brown ware; interior surface coated in white slip and covered with a light green glaze, which extends over the rim; some splashes of glaze on the exterior; some small and occasional large white grits.

Comparisons: Stern and Tatcher 2009: 126, fig. 3:18.2; see also Avissar and Stern 2005: 6-7, type I.1.1.3

No. 2: Bowl (Fig. 7:2 [scale 2:5])

Find Context: Locus 3106, Basket 30949\10 (2013)

Preservation: One sherd preserving a portion of the rim. Measurements: $1 \times 1 \mathrm{~cm}$

Clay: 10R 4/6

Description: Coarse red ware; evenly fired; surfaces coated in a white slip on which is a polychrome glaze (yellow and green); traces of fine sgraffito on interior; some small black and stony grits.

Comparison: Stacey 2004: 117-19, fig. 5:25-no exact parallels; may be the uppermost portion of a bowl with cyma-recta profile (esp. 5:25.1, 3-7)

\section{No. 3: Bowl (Fig. 7:3 [not to scale])}

Find Context: Locus 3129, Basket 31034\4 (2013)

Preservation: One sherd from the vessel body. 
Measurements: $4 \times 1.5 \mathrm{~cm}$

Clay: 5YR 7/4

Description: Fine-grained buff ware; evenly fired; interior surface coated in a white slip, on which is a yellow glaze with a splash of green glaze; some small white, black, and stony grits.

Comparison: Stacey 2004: 117-19, fig. 5:25

\section{No. 4: Bowl (Fig. 7:4 [not to scale])}

Find Context: Locus 3122, Basket 30967\18 (2013)

Preservation: One sherd from the vessel body.

Measurements: $1 \times 1 \mathrm{~cm}$

Clay: 10R 4/6

Description: Sandy dark red ware; evenly fired; interior surface decorated with traces of linear patterns pained in white slip, on which was placed a translucent green glaze; some small black and stony grits; some very small mineral inclusions.

Comparison: Avissar and Stern 2005: 19-21, type I.1.6.2

No. 5: (Bowl (Fig. 7:5 [not to scale])

Find Context: Locus 5152, Basket 51184\1 (2017)

Preservation: One sherd from the vessel body.

Measurements: $4.2 \times 2.5 \mathrm{~cm}$

Clay: 5Y 8/2-4

Description: Fine-grained yellowish cream-colored ware; interior and exterior surfaces coated in a white slip and a clear alkaline glaze; some small white/gray and stony grits.

Comparison: Stacey 2004: 110-15, fig. 5:20.5 (?)

\section{Area 3000, Stratum 5}

No. 6: Bowl (Fig. 7:6 [scale 2:5])

Find Context: Locus 5052, Basket 50384\6 (2016)

Preservation: One sherd preserving the rim; estimated $0.12 \%$ diameter preserved.

Measurements: Est. diameter: $20 \mathrm{~cm}$

Clay: 2.5YR 4/4

Description: Fine-grained reddish-brown ware; interior surface covered in a cream-colored slip and decorated with dark reddish-brown painted geometric decoration (2.5YR 3/3); some small-to-medium white, red, and stony grits; occasional small mineral grits (mica?).

Comparison: Stern 2016: 85-86, fig. 2:3
No. 7: Jug (Fig. 7:7 [scale 2:5])

Find Context: Locus 5033, Basket 50204\9 (2016)

Preservation: One sherd preserving the rim; est. $0.27 \%$ diameter preserved.

Measurements: Est. diameter: $9 \mathrm{~cm}$

Clay: 5YR 7/6

Description: Fine-grained light brownish-orange ware; surfaces fired reddish brown (2.5YR 6/6) and decorated with horizontal bands of dark purple paint (7.5YR 3/2) and spots of very dark green glaze; many small stony grits; occasional large white, red, and stone grits.

Comparison: Avissar 2005: 77-78, fig. 2:26.6

\section{No. 8: Coffeeltea cup (Fig. 7:8 [scale 2:5])}

Find Context: Locus 5011, Basket 50323\6, 7 (2016)

Preservation: Two sherds preserving the entire base (join).

Measurements: Est. diameter: $4.5 \mathrm{~cm}$

Clay: 5GY 4/2

Description: White porcelain with a green-colored painted lion on the base and traces of a purple-painted floral decoration on the exterior surface (5R 4/2); no visible grits.

Comparison: Boas 2000: 568-70

\section{No. 9: Coffee cup (Fig. 7:9 [scale 2:5])}

Find Context: Locus 5033, Basket 50204\7 (2016)

Preservation: One sherd preserving the base; est. 0.55\% diameter preserved.

Measurements: Est. diameter: $4 \mathrm{~cm}$

Clay: 5 Y $8 / 2$

Description: Hard-fired white ware covered in a transparent light yellowish over-glaze; base bears a stamp reading "Made in Japan" in red (7.5YR 4/8) paint/ink; no visible grits.

Comparison: None

No. 10: Tobacco pipe (Fig. 7:10 [scale 2:5])

Find Context: Locus 5009, Basket 50338\1 (2016)

Preservation: One sherd preserving the rim of the bowl. Measurements: Est. bowl opening diameter: $3 \mathrm{~cm}$

Clay: 7.5YR 6/1

Description: Fine-grained gray ware with a slipped and burnished dark reddish-brown exterior (2.5YR 3/2); some medium black grits.

Comparison: Avissar 2005: 89-90, type 5

\section{Appendix B: Huqoq Archaeobotanical Interim Report}

\section{Jessie George and Jennifer Ramsay}

The archaeobotanical analysis at Huqoq seeks to investigate the agricultural economy of the village over time. Through the analysis of charred macro-botanical material, the objective is to identify changes in trends in agricultural techniques, agricultural products, and processing behaviors from the earliest excavated strata at the 
Table 1. Cereal, Legume, and Fruit Species Identified by Period from the 2014-2016 Seasons

\begin{tabular}{|c|c|c|c|c|c|c|c|}
\hline Category & Scientific Name & $\begin{array}{l}\text { Common } \\
\text { Name }\end{array}$ & $\begin{array}{c}\text { 10th } \\
\text { Century }\end{array}$ & $\begin{array}{l}\text { 12th-13th } \\
\text { Centuries }\end{array}$ & Mamluk & $\begin{array}{l}\text { 15th-16th } \\
\text { Centuries }\end{array}$ & $\begin{array}{l}\text { 19th-20th } \\
\text { Centuries }\end{array}$ \\
\hline \multirow[t]{3}{*}{ Cereals } & Hordeum vulgare & Barley & $\mathrm{X}$ & $\mathrm{X}$ & $\mathrm{X}$ & $\mathrm{X}$ & $\mathrm{X}$ \\
\hline & Hordeum vulgare (hulled) & Hulled barley & & & $\mathrm{X}$ & $\mathrm{X}$ & \\
\hline & Triticum aestivum/durum & Bread wheat & $\mathrm{X}$ & $\mathrm{x}$ & $\mathrm{X}$ & $\mathrm{X}$ & $\mathrm{X}$ \\
\hline \multirow[t]{6}{*}{ Legumes } & Lens culinaris & Lentil & $\mathrm{X}$ & $\mathrm{X}$ & $\mathrm{X}$ & $\mathrm{X}$ & $\mathrm{X}$ \\
\hline & Vicia faba & Broad bean & $\mathrm{X}$ & & $\mathrm{X}$ & $\mathrm{X}$ & $\mathrm{X}$ \\
\hline & Vicia ervilia & Bitter vetch & & & $\mathrm{X}$ & $\mathrm{X}$ & $\mathrm{X}$ \\
\hline & Ceratonia siliqua & Carob & & & $\mathrm{X}$ & & \\
\hline & Cicer arietinum & Chickpea & & & & & $\mathrm{X}$ \\
\hline & Pisum sativum & Pea & & & & & $\mathrm{X}$ \\
\hline \multirow[t]{7}{*}{ Fruit } & Olea europaea & Olive & $\mathrm{X}$ & $\mathrm{X}$ & $\mathrm{X}$ & $\mathrm{X}$ & $\mathrm{X}$ \\
\hline & Prunus spp. & Stone fruit & $\mathrm{X}$ & $\mathrm{X}$ & $\mathrm{X}$ & $\mathrm{X}$ & \\
\hline & Vitis vinifera & Grape & $\mathrm{X}$ & & $\mathrm{X}$ & $\mathrm{X}$ & $\mathrm{X}$ \\
\hline & Ficus carica & Fig & & & $\mathrm{X}$ & & \\
\hline & Citrullus lanatus & Watermelon & & & $\mathrm{X}$ & & \\
\hline & Helianthus anuus & Sunflower & & & & & $\mathrm{X}$ \\
\hline & Ziziphus spina-christi & $\begin{array}{l}\text { Christ's thorn } \\
\text { jujube }\end{array}$ & & & & & $\mathrm{X}$ \\
\hline
\end{tabular}

start of the 5 th century C.E., coinciding with the construction of the Late Roman synagogue, to the 19th-20thcentury village of Yakuk. We hope that the identification of these changing trends will yield valuable information about the economic standing of the village and cultural influences over the various periods of occupation.

Soil samples for botanical analysis were taken during the 2014, 2015, and 2016 seasons. The sampling strategy employed was a "blanket sampling" approach, comprising at least one sample from each identified context (Pearsall 2000). This was not always possible or feasible for the entire extent of the period in question. Where sampling all contexts was not possible due to time constraints or logistical concerns, a subjective approach was employed, with sampling efforts concentrating on sealed loci and contexts directly connected to food processing and storage. A total of 85 soil samples were taken during the 2014-2016 seasons. The samples range in size from 6 to 18 liters, with a mean sample size of 14 liters. Fifteen samples were taken from Area 2000 (the ancient village) during the 2014 season. The remaining 70 samples were taken from Area 3000, which includes the modern village of Yakuk, the medieval public building, and the Late Roman synagogue. Of the 85 samples, 20 have been analyzed: 5 samples from Area 2000 and 15 from Area 3000 (Table 1).
A machine flotation system similar to the Shellmound Archaeological Project (SMAP) barrel system was used to process soil samples. The system uses a modified water heater as the main basin, replacing the barrel or oil drum used in SMAP systems. The machine possesses a single settling tank, which necessitates frequent cleaning between flotations to prevent contamination when water is recycled. Suspended botanical material separated from the sediment in the process of flotation is directed through an open spout into two geological sieves of $1 \mathrm{~mm}$ (coarse fraction) and $250 \mu \mathrm{m}$ (light fraction). Material too dense to be held in suspension in the agitated water (heavy fraction) settles to the bottom of the main tank and is then sorted for organic material in the field lab.

The dried and labeled samples were sent to the lab of Jennifer Ramsay at the College at Brockport, State University of New York, and to Jessie George at the Ancient Agriculture and Paleoethnobotany Laboratory (AAPL) at the University of California, Los Angeles, under the direction of Alan Farahani, for sorting and identification under a stereoscopic microscope at $40 \times$ magnification. Wood charcoal was separated out for future analysis, and any other diagnostic carbonized plant material was sorted out and identified by George, using the AAPL reference 


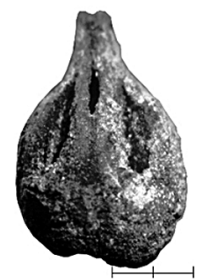

Fig. 50. Grape pip (Vitis vinifera) present in all but 12th-13th-century analyzed samples. (Scale is $2 \mathrm{~mm}$.) (Photo by J. Ramsay)

collection along with published reference material, and by Ramsay, through her personal reference collection.

\section{Area 2000}

During the last season of excavations of Area 2000 in 2014, 15 samples were taken from Squares SE 6/5, SE $5 / 5$, and SE 5/6. These samples continue the trends observed in samples taken from the 2012 season. Fruit species remain a dominant presence in Late Roman village samples, with the highest presence represented by olive (Olea europaea) and stone fruit species (Prunus spp.), and a single sample containing the remains of grape ( $\mathrm{Vi}$ tis vinifera) (Fig. 50). Wheat (Triticum spp.) continues to be the dominant cereal presence. As a generally preferred and less hardy and reliable grain than barley, this may be an indication of higher economic status of the village in this period. There is some evidence for consumption of legumes, but the material is poorly preserved and difficult to identify.

\section{Area 3000}

The complexity of Area 3000 and the range of periods represented yielded a much more varied botanical assemblage. During the 2014, 2015, and 2016 seasons, 70 samples were taken from the area in total (48 in 2014, 7 in 2015, and 15 in 2016). Of these, only 15 samples were analyzed; two were taken from 10th-century loci, two from 12th-13thcentury contexts, five were dated to the Mamluk period (13th-15th centuries), one from the Late Mamluk to Early

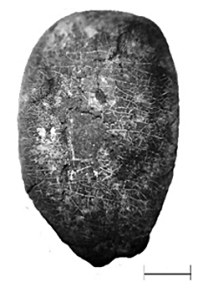

Fig. 51. Carob seed (Ceratonia siliqua) found only in a single Mamluk sample. (Scale is $2 \mathrm{~mm}$.) (Photo by J. George)

Ottoman period (15th-16th centuries), and five from the 19 th and 20th centuries. These dates were established on the basis of ceramic and numismatic evidence.

Whereas samples from 10th-century and 12th-13thcentury contexts show similar presences to the village material, Mamluk assemblages diverge from earlier periods. In the latter, the presence of barley (Hordeum vulgare) surpasses that of wheat. Consumption or preservation of legumes increases. Chickpea (Cicer arietinum), lentil (Lens culinaris), and, most notably, carob (Ceratonia siliqua) (Fig. 51), which is thus far absent from all other periods, are the most dominant Fabaceae present. Additionally, Mamluk samples reveal a higher presence of fig (Ficus carica) seeds and the highest presence of grape (Vitis vinifera) (Fig. 50).

Samples dated to the 19th and 20th centuries show an increase in wheat over barley in comparison with the Mamluk period. Fig remains a dominant presence for fruit consumed, with the addition of a substantial presence of Christ's thorn jujube (Ziziphus spina-christi), which may indicate human consumption or the use of dung for fuel. Legume presences at this time shift to pea (Pisum sativum), broad bean (Vicia faba), and bitter vetch (Vicia ervilia).

Our preliminary analysis of Huqoq's archaeobotanical material already indicates changes in food and agricultural practices over time. It is expected that as analysis of the material continues, more subtle patterns of the changing agricultural economy of the village will emerge, giving valuable information regarding the village's changing cultural and economic standing in the surrounding region.

\section{Appendix C: Radiocarbon Dating of a Charcoal Sample from the Huqoq Mosaic Bedding}

\section{Elisabetta Boaretto and Michael Chazan}

At the end of the 2013 season, the mosaic panel depicting Samson carrying the gate of Gaza, located at the southern end of the synagogue's east aisle, was removed for conservation and is now in the Israel Antiquities Authority's new facility in Jerusalem. At the beginning of the
2014 season, a section measuring ca. $1.75 \times 1.75 \mathrm{~m}$ was cut through the plaster bedding of the mosaic. The bedding (L3183) consisted of $1 \mathrm{~cm}$ of fine white plaster into which the tesserae had been laid (and which still preserved their impressions). Below this was a $3 \mathrm{~cm}$ thick layer of soft 
TABLE 2. Radiocarbon Dating of Charcoal Sample HQ $2014 \# 2$

\begin{tabular}{|c|c|c|c|c|c|c|c|c|}
\hline Lab No. & Type & $\begin{array}{l}C \\
\% \\
\end{array}$ & $\begin{array}{c}{ }^{14} \text { C Age } \\
\pm 1 \sigma \text { year B.P. }\end{array}$ & Locus & Basket & $\begin{array}{l}\text { Calibrated Range } \\
\pm 1 \sigma \text { year C.E. }\end{array}$ & $\begin{array}{c}\text { Calibrated Range } \\
\pm 2 \sigma \text { year C.E. }\end{array}$ & $\begin{array}{c}\text { Botanical } \\
\text { Identification }\end{array}$ \\
\hline $\begin{array}{l}\text { RTD } \\
7798.2\end{array}$ & Charcoal & 62.7 & $1675 \pm 16$ & 3183 & 31436 & $\begin{array}{l}350(31.7 \%) 370 \\
380(36.5 \%) 400\end{array}$ & $335(95.4 \%) 410$ & Cupressus sp. \\
\hline
\end{tabular}

gray plaster mixed with crushed pottery, charcoal, and ash. Charcoal and plaster samples were saved for analysis.

Three charcoal samples (B31436) directly collected from the plaster were selected based on their size for possible radiocarbon dating at the DANGOOR Research Accelerator Mass Spectrometry (D-REAMS) Laboratory at the Weizmann Institute of Science in Rehovot, Israel. Before chemical pre-treatment and preparation for the radiocarbon determination, the samples were analyzed for botanical identification. Of the three samples, only one retained wood structures allowing for botanical identification, and this sample was selected for dating. ${ }^{98}$ Table 2 presents all of the information about the sample, its radiocarbon age, and the calibrated range according to $\pm 1 \sigma$ ( \pm 1 standard deviation, meaning $68.2 \%$ probability that the true age is included in those limits) and $\pm 2 \sigma$ ( \pm 2 standard deviation, meaning $95.4 \%$ probability that the true age is included in those limits).

Sample pre-treatment to remove contaminants and preparation as graphite for the measurement with the accelerator was based on the procedure presented in

${ }^{98}$ In 2017, a suite of over 50 samples was taken from profiles through the fill below the medieval public building and below the synagogue's mosaic floor.
Yizhaq et al. 2005. The radiocarbon determination was done at the D-REAMS accelerator, as in Regev et al. 2017. Radiocarbon ages are reported in conventional radiocarbon years (before present $=1950$ ) in accordance with international convention (Stuiver and Polach 1977). Thus, all calculated ${ }^{14} \mathrm{C}$ ages have been corrected for fractionation, so the results are equivalent with the standard $\delta^{13} \mathrm{C}$ value of $-25 \%$ (wood). Calibrated ages in calendar years have been obtained from the calibration tables in Reimer et al. 2013 by means of the OxCal program (v. 4.2) (Bronk Ramsey 2010; see also 1995; 2001).

The sample, RTD 7798.2, was identified as Cupressus sp. (cypress) and was in a good state of preservation, as indicated by the high percentage of carbon, $62.7 \% \mathrm{C}$. As this could be a long-lived tree, the date should be considered a terminus post quem. The high-precision ${ }^{14} \mathrm{C}$ age of RTD 7798.2 is $1675 \pm 16$ years B.P., providing a calibrated range for $\pm 1 \sigma$ and $\pm 2 \sigma$ covering most of the 4 th century C.E. Based on this result, there is a $94.5 \%$ probability that $335-410$ C.E. is a terminus post quem for the preparation of the mosaic floor. We believe this is essential information for any chronological interpretation with the integration of the ceramic and numismatic evidence.

\section{Acknowledgments}

The roles of the contributors to this article and appendices are as follows: Magness (director); Kisilevitz (assistant director); Grey and Mizzi (supervisors of Area 3000); Schindler (ceramics); Wells (architecture); Britt and Boustan (mosaics); O'Connell (painted and molded plaster); Ramsay and George (palaeobotany); Hubbard (geoarchaeology); Boaretto and Chazan (radiocarbon dating). From 2014 to 2017, the following institutions were consortium members of the Huqoq Excavation Project: The University of North Carolina at Chapel Hill; Brigham Young University; the University of Toronto; Baylor University (2016-2017); and Trinity University (TX) (2014). We gratefully acknowledge the funding provided during these years by the consortium members and The William R. Kenan Jr. Charitable Trust; the National Geographic Society Expeditions Council and Waitt Grants Program; the Loeb Classical Library Foundation; the International Catacomb Society; the Dumbarton Oaks Re- search Library and Collection; the Memorial Foundation for Jewish Culture; The Foundation for Biblical Archaeology; and numerous individual donors. In addition to the authors of this article and the appendices, the staff members from 2014 to 2017 included Miki Golan (dig administrator); Orna Cohen (site conservator); Carolyn Swan (glass specialist); Nathan Elkins (numismatist); Haskel Greenfield and Annie Brown (zooarchaeologists); Brian Coussens and Jocelyn Burney (educational coordinators); Bradley Erickson (computer specialist and webmaster); Jim Haberman (photographer); Mary Robinson-Mohr (registrar); Randy Mohr (dig artist); Slava Pirsky (top plans and section drawings); Mimi Lavie (cleaning and conservation of artifacts); Arnold Frankin (medievalist); Griffin Higher Photography (aerial photos); and Paul Flesher (computer specialist [2012-2015] and educational director [2014]). Finally, we thank the two anonymous $B A S O R$ reviewers for their helpful comments. 


\section{References}

Adan-Bayewitz, D.

1993 Common Pottery in Roman Galilee: A Study of Local Trade. Bar-Ilan Studies in Near Eastern Languages and Culture. Ramat-Gan: Bar-Ilan University.

Amit, D.

1995 Architectural Plans of Synagogues in the Southern Judean Hills and the "Halakah." Pp. 129-56 in Ancient Synagogues: Historical Analysis and Archaeological Discovery, Vol. 1, ed. D. Urman and P. V. M. Flesher. Studia Post-Biblica 47 (1). Leiden: Brill.

1998 A Marble Menorah from the Ancient Synagogue at Ma'on. Judea and Samaria Research Studies 7: 15568 (Hebrew; English summary on pp. xvi-xvii).

2007 The Dating of Ancient Synagogues. Cathedra 124: 6-12 (Hebrew).

2013 Mosaic Inscription from a Synagogue at Horvat Huqoq. Bible History Daily, January 2. https://www. biblicalarchaeology.org/daily/biblical-artifacts/ inscriptions/mosaic-inscription-from-a-synagogueat-horvat-huqoq (accessed May 22, 2018).

Arce, J., ed.

2002 Centcelles: El monumento tardorromano; Iconografía y arquitectura. Rome: Bretschneider.

Arubas, B. Y., and Talgam, R.

2014 Jews, Christians and "Minim": Who Really Built and Used the Synagogue at Capernaum-A Stirring Appraisal. Pp. 237-74 in Knowledge and Wisdom: Archaeological and Historical Essays in Honour of Leah Di Segni, ed. G. C. Bottini, L. D. Chrupcała, and J. Patrich. Publications of the Studium Biblicum Franciscanum 54. Jerusalem: Terra Santa.

Avissar, M.

2005 The Pottery. Pp. 35-78 in Tel Yoqne'am: Excavations on the Acropolis, by M. Avissar. IAA Reports 25. Jerusalem: Israel Antiquities Authority.

Avissar, M., and Stern, E. J.

2005 Pottery of the Crusader, Ayyubid, and Mamluk Periods in Israel. IAA Reports 26. Jerusalem: Israel Antiquities Authority.

Avi-Yonah, M.

1961 Synagogue Architecture in the Classical Period. Pp. 157-90 in Jewish Art: An Illustrated History, ed. C. Roth. New York: McGraw-Hill.

1981 The Mosaics of Mopsuestia-Church or Synagogue? Pp. 186-90 in Ancient Synagogues Revealed, ed. L. I. Levine. Jerusalem: Israel Exploration Society.

Avshalom-Gorni, D., and Najar, A.

2013 Migdal. Hadashot Arkheologiyot-Excavations and Surveys in Israel 125. http://www.hadashot-esi.org. il/report_detail_eng.aspx?id=2304\&mag_id=120 (accessed May 22, 2018).

Bahat, D.

1981 A Synagogue at Beth-Shean. Pp. 82-85 in Ancient Synagogues Revealed, ed. L. I. Levine. Jerusalem: Israel Exploration Society.
Balty, J.

1977 Mosaïques antiques de Syrie. Brussels: Centre Belge de recherches archéologiques à Apamée de Syrie.

1995 Mosaïques antiques du Proche-Orient: Chronologie, iconographie, interprétation. Centre de recherches d'histoire ancienne 140; Annales littéraires de l'Université de Besançon, 551. Paris: Belles Lettres.

Barag, D.

1993 En-Gedi: The Synagogue. NEAEHL 2: 405-9.

Baramki, D. C.

1972 A Byzantine Church at Mahat el Urdi, Beit Jibrin, 1941-1942. Liber Annuus 22: 130-52.

Bar-Kochva, B.

2010 The Image of the Jews in Greek Literature: The Hellenistic Period. Hellenistic Culture and Society 51. Berkeley: University of California Press.

Ben David, C.

2005 The Jewish Settlement on the Golan in the Roman and Byzantine Period in Light of the Finds of the Archaeological Survey in the Lower Golan. Golan Studies 1. Qazrin: Golan Research Institute (Hebrew).

Biebel, F. M.

1938 The Synagogue Church. Pp. 318-24 in Gerasa, City of the Decapolis, ed. C. H. Kraeling. New Haven, CT: American Schools of Oriental Research.

Boas, A. J.

2000 Pottery and Small Finds from the Late Ottoman Village and the Early Zionist Settlement. Pp. 54780 in Ramat Hanadiv Excavations: Final Report of the 1984-1998 Seasons, ed. Y. Hirschfeld. Jerusalem: Israel Exploration Society.

Bodnaruk, M.

2015 Producing Distinction: Aristocratic and Imperial Representation in the Constantinian Age. Pp. 135-55 in Shifting Genres in Late Antiquity, ed. G. Greatrex and H. Elton with the assistance of L. McMahon. London: Routledge.

Britt, K., and Boustan, R.

2017 The Elephant Mosaic Panel in the Synagogue at Huqoq: Official Publication and Initial Interpretations. Journal of Roman Archaeology Supplementary Series 106. Portsmouth, RI: Journal of Roman Archaeology.

Bronk Ramsey, C.

1995 Radiocarbon Calibration and Analysis of Stratigraphy: The OxCal Program. Radiocarbon 37: 425-30.

2001 Development of the Radiocarbon Calibration Program OxCal. Radiocarbon 43: 355-63.

2010 OxCal 4.2. https://c14.arch.ox.ac.uk/oxcal.html (accessed May 31, 2018).

Budde, L.

1960 Die frühchristlichen Mosaiken von Misis-Mopsuhestia in Kilikien. Pantheon 18: 116-26.

1969 Antike Mosaiken in Kilikien, Vol. 1: Frühchristliche Mosaiken in Misis-Mopsuhestia. Beiträge zur 
Kunst des christlichen Ostens 5. Recklinghausen: Bongers.

Buschhausen, $\mathrm{H}$.

1972 Die Deutung des Archemosaiks in der Justinianischen Kirche von Mopsuestia. Jahrbuch der österreichischen Byzantinistik 21: 57-72.

Carandini, A.; Ricci, A.; and de Vos, M.

1982 Filosofiana, the Villa of Piazza Armerina: The Image of a Roman Aristocrat at the Time of Constantine. 2 vols. Trans. M. C. Keith, from Italian. Palermo: Flaccovio.

Chéhab, M.

1958- Mosaïques du Liban. 2 vols. Bulletin du Musée de 1959 Beyrouth 14, 15. Paris: Maisonneuve.

Crowfoot J. W., and Hamilton, R. W.

1929 The Discovery of a Synagogue at Jerash. Palestine Exploration Quarterly 61: 211-19.

Deliyannis, D. M.

2010 Ravenna in Late Antiquity. Cambridge: Cambridge University Press.

De Luca, S., and Lena, A.

2014 The Mosaic of the Thermal Bath Complex of Magdala Reconsidered: Archaeological Context, Epigraphy and Iconography. Pp. 1-33 in Knowledge and Wisdom: Archaeological and Historical Essays in Honour of Leah Di Segni, ed. G. C. Bottini, L. D. Chrupcała, and J. Patrich. Jerusalem: Terra Santa.

Dothan, M.

1983 Hammath Tiberias: Early Synagogues and the Hellenistic and Roman Remains. Ancient Synagogues Studies. Jerusalem: Israel Exploration Society.

Dresken-Weiland, J.

1995 Ein frühchristliches Jonah-relief in Iconium. Mitteilungen des Deutschen Archäologischen Instituts, Römische Abteilung 102: 405-12.

Dunbabin, K. M. D.

1978 The Mosaics of Roman North Africa: Studies in Iconography and Patronage. New York: Clarendon.

1999 Mosaics of the Greek and Roman World. Cambridge: Cambridge University Press.

Engemann, J.

1997 Deutung und Bedeutung frühchristlicher Bildewerke. Darmstadt: Primus.

Epstein, J. N., and Melamed, E. Z., eds.

1955 Mekhilta d'Rabbi Shim 'on b. Jochai. Jerusalem: Mekitse Nirdamim (Hebrew).

Feldman, L. H.

1992 Josephus' Interpretation of Jonah. Association of Jewish Studies Review 17: 1-29.

1999- Rearrangement of Pentateuchal Narrative Material

2000 in Josephus' Antiquities, Books 1-4. Hebrew Union College Annual 70-71: 129-51.

Ferrua, A.

1991 The Unknown Catacomb: A Unique Discovery of Early Christian Art. Trans. I. Inglis, from Italian. New Lanark, U.K.: Geddes \& Grosset.
Fine, S., and Meyers, E. M.

1997 Synagogues. Pp. 118-23 in The Oxford Encyclopedia of Archaeology in the Near East, Vol. 5, ed. E. M. Meyers. New York: Oxford University Press.

Finkel, I.

2014 The Ark before Noah: Decoding the Story of the Flood. London: Hodder \& Stoughton.

Fleischer, E.

1988 Eretz-Israel Prayer and Prayer Rituals as Portrayed in the Geniza Documents. Jerusalem: Magnes (Hebrew).

Foerster, G.

1978 The Story of Jonah on the Mosaic Pavement of a Church at Beth Govrin. Pp. 289-94 in Atti del IX Congresso Internazionale di Archeologia Cristina, Roma, 21-27 settembre 1975, Vol. 2. Rome: Pontificio Istituto di Archeologia Cristiana.

1987 The Zodiac in Ancient Synagogues and Its Place in Jewish Thought and Literature. Eretz-Israel 19: 225-34 (Hebrew; English abstract on p. 79*).

2004 Has There Indeed Been a Revolution in the Dating of Galilean Synagogues? Pp. 526-29 in Continuity and Renewal: Jews and Judaism in Byzantine-Christian Palestine, ed. L. I. Levine. Jerusalem: Dinur Center for the Study of the History of Israel; Yad Izhak Ben-Zvi (Hebrew).

Fogel, S.

2009 "Samson's Shoulders Were Sixty Cubits": Three Issues about Samson's Image in the Eyes of the Rabbis. M.A. thesis, Ben-Gurion University of the Negev (Hebrew).

Friedman, M. A.

1984 The Verb אתחזק in Palestinian Synagogue Inscriptions. Tarbiz 53: 605-6 (Hebrew).

Friedman, Z.

2004 The Ships Depicted in the Lod Mosaic Reconsidered. International Journal of Nautical Archaeology 33: $164-68$.

Ginzberg, L.

1998 The Legends of the Jews. 2nd ed. 7 vols. Trans. H. Szold, from Hebrew. Baltimore: Johns Hopkins University Press.

Goldenberg, D. M.

2003 The Curse of Ham: Race and Slavery in Early Judaism, Christianity, and Islam. Princeton: Princeton University Press.

Goldin, J.

1971 The Song at the Sea: Being a Commentary on a Commentary in Two Parts. New Haven, CT: Yale University Press.

Goodenough, E. R.

1953- Jewish Symbols in the Greco-Roman Period. 13 vols. 1968 Bollingen Series 37. New York: Pantheon.

Grabar, A.

1966 Une thème de l'iconographie chrétienne: L’oiseau dans la cage. Cahiers archéologiques 16: 9-16. 
Gregg, R. C.

2015 Shared Stories, Rival Tellings: Early Encounters of Jews, Christians, and Muslims. New York: Oxford University Press.

Grey, M. J.

2013 "The Redeemer to Arise from the House of Dan": Samson, Apocalypticism, and Messianic Hopes in Late Antique Galilee. Journal for the Study of Judaism 44: 553-89.

Guidetti, P., and Micheli, F.

2011 Ancient Art Serving Marine Conservation: PeerReviewed Letter. Frontiers in Ecology and the Environment 9: 374-75.

Gundel, $\mathrm{H}$.

1992 Zodiakos: Tierkreisbilder im Altertum; Kosmische Bezüge und Jenseitvorstellungen im antiken Alltagsleben. Kulturgeschichte der antiken Welt 54. Mainz: Zabern.

Hachlili, R.

2002 The Zodiac in Ancient Jewish Synagogal Art: A Review. Jewish Studies Quarterly 9: 219-58.

2009 Ancient Mosaic Pavements: Themes, Issues, and Trends; Selected Studies. Leiden: Brill.

2013 Ancient Synagogues-Archaeology and Art: New Discoveries and Current Research. Handbook of Oriental Studies 1, The Near and Middle East 105. Leiden: Brill.

Haddad, E., and Avissar, M.

2003 A Suggested Reconstruction of One of the Merchant Ships on the Mosaic Floor in Lod (Lydda), Israel. International Journal of Nautical Archaeology 32: 73-77.

Hasan-Rokem, G.

2014 Leviticus Rabbah 16,1-“Odysseus and the Sirens" in the Beit Leontis Mosaic from Beit She'an. Pp. 159-89 in Talmuda de-Eretz Israel: Archaeology and the Rabbis in Late Antique Palestine, ed. S. Fine and A. Koller. Studia Judaica 73. Berlin: de Gruyter.

Hayes, J. W.

1972 Late Roman Pottery. London: British School at Rome.

Hirschfeld, Y.

1995 The Palestinian Dwelling in the Roman-Byzantine Period. Studium Biblicum Franciscanum, Collectio Minor 34. Jerusalem: Franciscan Printing Press; Israel Exploration Society.

Hofstetter, E., and Krauskopf, I.

1997 Seirenes. Pp. 1093-104 in Lexicon Iconographicum Mythologiae Classicae, Vol. 8: Thespiades-Zodiacus et Supplementum Abila-Thersites, Part 1. Zurich: Artemis.

Horovitz, S., and Rabin, I. A., eds.

1997 Mekhilta de-Rabbi Ishmael. 2nd ed. Jerusalem: Shalem (Hebrew).

Ilan, Z.

1993 Meroth. NEAEHL 3: 1028-31.
1995 The Synagogue and Study House at Meroth. Pp. 256-88 in Ancient Synagogues: Historical Analysis and Archaeological Discovery, Vol. 1, ed. D. Urman and P. V. M. Flesher. Studia Post-Biblica 47 (1). Leiden: Brill.

Ilan, Z., and Damati, E., eds.

1987 Meroth: The Ancient Jewish Village; The Excavations at the Synagogue and Bet-Midrash. Tel Aviv: Society for the Protection of Nature in Israel (Hebrew).

Ilan, Z., and Izdarechet, A.

1993 Arbel. NEAEHL 1: 87-89.

Işık, $\mathrm{F}$.

2007 Girlanden-Sarkophage aus Aphrodisias. Mainz: Zabern.

Jacobson, $\mathrm{H}$.

1996 A Commentary on Pseudo-Philo's Liber Antiquitatum Biblicarum. Arbeiten zur Geschichte des antiken Judentums und des Urchristentums 31. Leiden: Brill.

Jellinek, A., ed.

1967 Bet ha-Midrasch. 3rd ed. 6 vols. Jerusalem: Wahrmann Books.

Kadari, T.

2002 The Repentance of Jonah the Prophet. Kobez Al Yad, Minora Manuscripta Hebraica 16: 67-84 (Hebrew).

2016 Aggadic Motifs in the Story of Jonah: A Study of Interaction between Religions. Pp. 107-25 in Religious Stories in Transformation: Conflict, Revision and Reception, ed. A. Houtman, T. Kadari, M. Poorthuis, and V. Tohar. Jewish and Christian Perspectives Series 31. Leiden: Brill.

Kitzinger, E.

1965 The Stylistic Developments in Pavement Mosaics in the Greek East from the Age of Constantine to the Age of Justinian. Pp. 341-52 in La mosäique gréco-romaine: Actes du colloque international sur la mosaïque antique organisé à Paris, du 29 août au 3 septembre 1963, ed. C.-P. Gilbert and H. Stern. Paris: Éditions du Centre National de la Recherche Scientifique.

1973 Observations on the Samson Floor at Mopsuestia. Dumbarton Oaks Papers 27: 133-44.

Kohl, H., and Watzinger, C.

1916 Antike Synagogen in Galilaea. Wissenschaftliche Veröffentlichungen der Deutschen Orient-Gesellschaft 29. Leipzig: Hinrichs.

Kondoleon, C.

2000 Mosaic of Tethys. Pp. 152-53 in Antioch: The Lost Ancient City, ed. C. Kondoleon. Princeton: Princeton University Press in association with the Worcester Art Museum.

Lapin, $\mathrm{H}$.

2017 Population Contraction in Late Roman Galilee: Reconsidering the Evidence. Bulletin of the American Schools of Oriental Research 378: 127-43. 
Lavin, I.

1963 The Hunting Mosaics of Antioch and Their Sources: A Study of Compositional Principles in the Development of the Early Medieval Style. Dumbarton Oaks Papers 17: 179-286.

Leibner, $\mathrm{U}$.

2004 History of Settlement in the Eastern Galilee during the Hellenistic, Roman and Byzantine Periods in Light of an Archaeological Survey. Ph.D. dissertation, Bar-Ilan University (Hebrew).

2009a Settlement and History in Hellenistic, Roman, and Byzantine Galilee: An Archaeological Survey of the Eastern Galilee. Texts and Studies in Ancient Judaism 127. Tübingen: Mohr Siebeck.

2009b The Settlement Crisis in the Eastern Galilee during the Late Roman and Early Byzantine Periods: Response to Jodi Magness. Pp. 314-19 in Jewish Identities in Antiquity: Studies in Memory of Menahem Stern, ed. L. I. Levine and D. R. Schwartz. Texts and Studies in Ancient Judaism 130. Tübingen: Mohr Siebeck.

2010 Excavations at Khirbet Wadi Hamam (Lower Galilee): The Synagogue and the Settlement. Journal of Roman Archaeology 23: 220-37.

2014 An Illustrated Midrash of Mekilta de R. Ishmael, Vayehi Beshalah, 1-Rabbis and the Jewish Community Revisited. Pp. 83-96 in Talmuda de-Eretz Israel: Archaeology and the Rabbis in Late Antique Palestine, ed. S. Fine and A. Koller. Studia Judaica 73. Berlin: de Gruyter.

Leibner, U., and Arubas, B. Y.

2015 Summary of the Excavation Project at Khirbet Wadi Hamam, a Roman Period Village in the Galilee. Qadmoniot 149: 28-39 (Hebrew).

Leibner, U., and Ben David, C.

2014 Imported Fine Ware in Palaestina Secunda: Geographic, Economic, and Ethnic Aspects. Bulletin of the American Schools of Oriental Research 371: 185-201.

Leibner, U., and Miller, S.

2010 A Figural Mosaic in the Synagogue at Khirbet Wadi Hamam. Journal of Roman Archaeology 23: 238-64.

Levi, D.

1947 Antioch Mosaic Pavements. 2 vols. Publications of the Committee for the Excavation of Antioch and Its Vicinity 4. Princeton: Princeton University Press.

Levine, L. I.

1981 The Inscription in the 'En-Gedi Synagogue. Pp. 140-45 in Ancient Synagogues Revealed, ed. L. I. Levine. Jerusalem: Israel Exploration Society.

1993 'Ammudim, Horvat. NEAEHL 1: 55-56.

2005 The Ancient Synagogue: The First Thousand Years. 2nd ed. New Haven, CT: Yale University Press.

2012 Visual Judaism in Late Antiquity: Historical Contexts of Jewish Art. New Haven, CT: Yale University Press.

Lieber, L.

2008 Confessing from A to Z: Penitential Forms in Early Synagogue Poetry. Pp. 99-125 in Seeking the Favor of God, Vol. 3: The Impact of Penitential
Prayer beyond Second Temple Judaism, ed. M. J. Boda, D. K. Falk, and R. A. Werline. Early Judaism and Its Literature 23. Atlanta: Society of Biblical Literature.

Lightfoot, C. S.

2010 The Roman Mosaic from Lod, Israel. The Metropolitan Museum of Art Blog, September 23. https:// www.metmuseum.org/blogs/now-at-the-met/ features/2010/the-roman-mosaic-from-lod-israel (accessed May 31, 2018)

$L I M C=$ Ackerman, H. C., and Gisler, J.-R., eds.

1981- Lexicon Iconographicum Mythologiae Classicae. 10 2009 vols. in 11. Zurich: Artemis.

Ling, R.

1979 Hylas in Pompeian Art. Mélanges d'archéologie et d'histoire de l'Ecole française de Rome 91: 773-816.

Lowden, J.

1997 Early Christian and Byzantine Art. Art \& Ideas. London: Phaidon.

Mackie, G.

2003 Early Christian Chapels in the West: Decoration, Function, and Patronage. Toronto: University of Toronto Press.

Magness, J.

1993 Jerusalem Ceramic Chronology, circa 200-800 CE. JSOT/ASOR Monograph Series 9. Sheffield: Sheffield Academic.

1997 Synagogue Typology and Earthquake Chronology at Khirbet Shema', Israel. Journal of Field Archaeology 24: 211-20.

2001 The Question of the Synagogue: The Problem of Typology. Pp. 1-48 in Judaism in Late Antiquity, Part 3: Where We Stand; Issues and Debates in Ancient Judaism, Vol. 4: The Special Problem of the Synagogue, ed. A. J. Avery-Peck and J. Neusner. Handbook of Oriental Studies 1, The Near and Middle East 55. Leiden: Brill.

2009 Did Galilee Experience a Settlement Crisis in the Mid-Fourth Century? Pp. 296-313 in Jewish Identities in Antiquity: Studies in Memory of Menahem Stern, ed. L. I. Levine and D. R. Schwartz. Texts and Studies in Ancient Judaism 130. Tübingen: Mohr Siebeck.

2010 The Ancient Synagogue at Nabratein. Bulletin of the American Schools of Oriental Research 358: 61-68.

2012 The Pottery from the Village of Capernaum and the Chronology of Galilean Synagogues. Tel Aviv 39: $110-22$.

2013 Samson in the Synagogue. Biblical Archaeology Review 39 (1): 32-39, 66-67.

Magness, J.; Kisilevitz, S.; Britt, K.; Grey, M.; and Spigel, C.

2014 Huqoq (Lower Galilee) and Its Synagogue Mosaics: Preliminary Report on the Excavations of 2011-13. Journal of Roman Archaeology 27: 327-55.

Magness, J.; Kisilevitz, S.; Grey, M.; Mizzi, D.; and Britt, K.

2016a Huqoq-2015. Hadashot Arkheologiyot-Excavations and Surveys in Israel 128. http://www.hadashot-esi. org.il/report_detail_eng.aspx?id=25060\&mag_ id=124 (accessed May 22, 2018). 
2017 Huqoq-2016. Hadashot Arkheologiyot-Excavations and Surveys in Israel 129. http://www.hadashot-esi. org.il/report_detail_eng.aspx?id=25304\&mag_id= 125 (accessed May 22, 2018).

2018 Huqoq-2017. Hadashot Arkheologiyot-Excavations and Surveys in Israel 130. http://www. hadashot-esi.org.il/report_detail_eng.aspx?id= 25419 (accessed May 22, 2018).

Magness, J.; Kisilevitz, S.; Grey, M.; Spigel, C.; Gordon, B.; Coussens, B.; and Britt, $\mathrm{K}$.

2016b Huqoq-2014. Hadashot Arkheologiyot-Excavations and Surveys in Israel 130. http://www. hadashot-esi.org.il/report_detail_eng.aspx?id= 25057 (accessed May 22, 2018).

Magness, J., and Schindler, D.

2015 Pottery and Jewish Settlement in Late Roman Galilee. Bulletin of the American Schools of Oriental Research 374: 191-207.

Maguire, $\mathrm{H}$.

1991- An Early Christian Marble Relief at Kavala. Del1992 tion tes Christianikes Archaiologikes Etaireias 16: 283-95.

2000 Profane Icons: The Significance of Animal Violence in Byzantine Art. Res: Anthropology and Aesthetics 38: $18-33$.

Mann, J.

1925 Genizah Fragments of the Palestinian Order of Service. Hebrew Union College Annual 2: 269-338.

$\mathrm{Ma}^{\mathrm{c}} \mathrm{Oz}, \mathrm{Z}$. U.

1981 The Art and Architecture of the Synagogues of the Golan. Pp. 98-115 in Ancient Synagogues Revealed, ed. L. I. Levine. Jerusalem: Israel Exploration Society.

1993 Golan: Hellenistic Period to the Middle Ages. NEAEHL 2: 534-46.

1999 The Synagogue at Capernaum: A Radical Solution. Pp. 137-48 in The Roman and Byzantine Near East 2: Some Recent Archaeological Research, ed. J. H. Humphrey. Journal of Roman Archaeology Supplementary Series 31. Portsmouth, RI: Journal of Roman Archaeology.

Marzano, A.

2013 Harvesting the Sea: The Exploitation of Marine Resources in the Roman Mediterranean. Oxford Studies on the Roman Economy. Oxford: Oxford University Press.

Mazor, G., and Bar Nathan, R.

1998 Bet She'an, Antiquities Authority Excavation. Excavations and Surveys in Israel 17: 7-36.

Meyers, E. M.; Kraabel, A. T.; and Strange, J. F.

1976 Ancient Synagogue Excavations at Khirbet Shema', Upper Galilee, Israel, 1970-1972. Meiron Excavation Project 1; Annual of the American Schools of Oriental Research 42. Durham, NC: Published for the American Schools of Oriental Research by Duke University Press.

Meyers, E. M., and Meyers, C. L.

2009 Excavations at Ancient Nabratein: Synagogue and Environs. Meiron Excavation Project, 6. Winona Lake, IN: Published for the American Schools of Oriental Research by Eisenbrauns.
Meyers, E. M.; Meyers, C. L.; and Strange, J. F.

1990 Excavations at the Ancient Synagogue of Gush Halav. Meiron Excavation Project 5. Winona Lake, IN: Published for the American Schools of Oriental Research by Eisenbrauns.

Mikva, R. S

2012 Midrash vaYosha: A Medieval Midrash on the Song at the Sea. Texts and Studies in Medieval and Early Modern Judaism 28. Tübingen: Mohr Siebeck.

Miles, M. R.

1993 Santa Maria Maggiore’s Fifth-Century Mosaics: Triumphal Christianity and the Jews. Harvard Theological Review 86: 155-75.

Moon, W. G.

1992 Nudity and Narrative: Observations on the Frescoes from the Dura Synagogue. Journal of the American Academy of Religion 60: 587-658.

Naeh, S.

2006 The Role of Biblical Verses in Prayer According to the Rabbinic Tradition. Pp. 43-59 in Prayers That Cite Scripture, ed. J. L. Kugel. Cambridge, MA: Harvard University Center for Jewish Studies.

Naveh, J.

1978 On Stone and Mosaic: The Aramaic and Hebrew Inscriptions from Ancient Synagogues. Jerusalem: Israel Exploration Society (Hebrew).

NEAEHL $=$ Stern, E., ed.

1993- The New Encyclopedia of Archaeological Excavations 2008 in the Holy Land. 5 vols. Jerusalem: Israel Exploration Society; Carta; New York: Simon \& Schuster; Washington, DC: Biblical Archaeology Society.

Olszewski, M. T., and Saad, H.

2017 Wanted: A Remarkable Piece of History. Popular Archaeology 28. http://popular-archaeology.com/ issue/fall-2017/article/wanted-a-remarkable-pieceof-history (accessed May 22, 2018).

Ovadiah, R.

1974 Jonah in a Mosaic Pavement at Beth Guvrin. Israel Exploration Journal 24: 214-15.

Parlasca, K.

1959 Die römischen Mosaiken in Deutschland. Römisch-Germanische Forschungen 23. Berlin: de Gruyter.

Patrich, J., and Tsafrir, Y.

1993 A Byzantine Church Complex at Horvath Beit Loya. Pp. 265-72 in Ancient Churches Revealed, ed. Y. Tsafrir. Jerusalem: Israel Exploration Society.

Pearsall, D. M.

2000 Paleoethnobotany: A Handbook of Procedures. 2nd ed. San Diego, CA: Academic Press.

Piccirillo, M.

1992 The Mosaics of Jordan. American Center for Oriental Research Publications 1. Amman: American Center for Oriental Research.

Regev, L.; Steier, P.; Shachar, Y.; Mintz, E.; Wild, E. M.; Kutschera, W.; and Boaretto, E.

2017 D-REAMS: A New Compact AMS for Radiocarbon Measurements at the Weizmann Institute of Science, Rehovot, Israel. Radiocarbon 59: 775-84. 
Reimer, P. J.; Bard, E.; Bayliss, A.; Beck, J. W.; Blackwell, P. G.; Bronk Ramsey, C.; Buck, C. E.; Cheng, H.; Edwards, R. L.; Friedrich, M.; Grootes, P. M.; Guilderson, T. P.; Haflidason, H.; Hajdas, I.; Hatté, C.; Heaton, T. J.; Hoffmann, D. L.; Hogg, A. G.; Hughen, K. A.; Kaiser, K. F.; Kromer, B.; Manning, S. W.; Niu, M.; Reimer, R. W.; Richards, D. A.; Scott, E. M.; Southon, J. R.; Staff, R. A.; Turney, C. S. M.; and van der Plicht, J.

2013 IntCal13 and Marine13 Radiocarbon Age Calibration Curves 0-50,000 Years cal вр. Radiocarbon 55: 1869-87.

Roussin, L. A.

1995 East Meets West: The Mosaics of the Villa at 'Ein Yael (Jerusalem). Pp. 31-42 in Fifth International Colloquium on Ancient Mosaics, Held at Bath, England, on September 5-12, 1987, under the Aegis of L'Association Internationale pour l'Étude de la Mosaïque Antique and Organized by The Association for the Study and Preservation of Roman Mosaics, Part 2, ed. P. Johnson, R. Ling, and D. J. Smith. Journal of Roman Archaeology Supplementary Series 9 (2). Ann Arbor, MI: Journal of Roman Archaeology.

Schindler, D. J.

2017 Late Roman and Byzantine Galilee: A Provincial Case Study from the Perspective of the Imported and Common Pottery. Ph.D. dissertation, University of North Carolina at Chapel Hill.

Seager, A. R., and Kraabel, A. T.

1983 The Synagogue and the Jewish Community. Pp. 16890 in Sardis from Prehistoric to Roman Times: Results of the Archaeological Exploration of Sardis, 1958-1975, ed. G. M. A. Hanfmann, W. E. Mierse, and C. Foss. Cambridge, MA: Harvard University Press.

Spier, J., ed.

2007 Picturing the Bible: The Earliest Christian Art. New Haven, CT: Yale University Press.

Spigel, C.

2016 Debating Ancient Synagogue Dating: The Implications of Deteriorating Data. Bulletin of the American Schools of Oriental Research 376: 83-100.

Spiro, M.

1990 Pegasos and the Seasons in a Pavement from Caesarea Maritima. Pp. 31-44 in IL 60: Essays Honoring Irving Lavin on His Sixtieth Birthday, ed. M. Aronberg Lavin. New York: Italica.

Stacey, D.

2004 The Pottery. Pp. 89-147 in Excavation at Tiberias, 1973-1974: The Early Islamic Periods, ed. D. Stacey. IAA Reports 21. Jerusalem: Israel Antiquities Authority.

Stern, E. J.

2016 The Ceramic Finds from the Ottoman Flour Mills in the Ridwan Gardens, 'Akko. 'Atiqot 87: 83-96.

Stern, E. J., and Tatcher A.

2009 The Early Islamic, Crusader, and Mamluk Pottery. Pp. 118-75 in Horbat 'Uza: The 1991 Excavations,
Vol. 2, The Late Periods, by N. Getzov, D. AvshalomGorni, Y. Gorin-Rosen, E. J. Stern, D. Syon, and A. Tatcher. IAA Reports 42. Jerusalem: Israel Antiquities Authority.

Stichel, R.

1978 Die Inschriften des Samson-Mosaiks in Mopsuestia und ihre Beziehung zum biblischen Text. Byzantinische Zeitschrift 71: 50-61.

Stöger, $\mathrm{H}$.

2011 The Spatial Organization of the Movement Economy: The Analysis of Ostia's Scholae. Pp. 215-42 in Rome, Ostia, Pompeii: Movement and Space, ed. R. Laurence and D. J. Newsome. Oxford: Oxford University Press.

Stuiver, M., and Polach, H. A.

1977 Discussing Reporting ${ }^{14} \mathrm{C}$ Data. Radiocarbon 19: 355-63.

Sukenik, E. L.

1932 The Ancient Synagogue of Beth Alpha: An Account of the Excavations Conducted on Behalf of The Hebrew University, Jerusalem. Jerusalem: Hebrew University Press; London: Oxford University Press.

1934 Ancient Synagogues in Palestine and Greece. Schweich Lectures 1930. London: Published for the British Academy by Humphrey Milford, Oxford University Press.

1951 The Ancient Synagogue at Yafa near Nazareth. Bulletin of the Louis M. Rabinowitz Fund for the Exploration of Ancient Synagogues 2: 6-24.

Talgam, R.

2012 Constructing Identity through Art: Jewish Art as a Minority Culture in Byzantium. Pp. 399-454 in Jews in Byzantium: Dialectics of Minority and Majority Cultures, ed. R. Bonfil, O. Irshai, G. G. Stroumsa, and R. Talgam. Jerusalem Studies in Religion and Culture 14. Leiden: Brill.

2014 Mosaics of Faith: Floors of Pagans, Jews, Samaritans, Christians, and Muslims in the Holy Land. Treasures of the Past. Jerusalem: Yad Izhak BenZvi; University Park, PA: Pennsylvania State University Press.

2015 The Late Roman Mosaics at Lod. Pp. 50-107 in The Lod Mosaic: A Spectacular Roman Mosaic Floor. New York: Scala Arts \& Heritage.

2018 An Illustration of the Third Book of Maccabees in a Late-Antique Galilean Synagogue? Journal of Roman Archaeology 31: 1-11.

Touchefeu-Meynier, O.

1992 Odysseus. LIMC 6 (1): 962-64.

Travis, W. J.

2002 Of Sirens and Onocentaurs: A Romanesque Apocalypse at Montceaux-l'Etoile. Artibus et Historiae 23 (45): 29-62.

Tsafrir, Y.

1989 The Synagogue at Meroth, the Synagogue at Capernaum, and the Dating of Galilean Synagogues: A Reconsideration. Eretz-Israel 20: 337-44 (Hebrew). 
Vincent, L.-H.

1961 Un sanctuaire dans la région de Jéricho: La synagogue de Na'arah. Revue biblique 68: 163-77.

Vitto, F.

2014 Could the Biblical Story about Jonah and the Fish Have Appeared in Jewish Art? Paper presented at The 40th Annual Archaeological Congress of Israel, University of Haifa, Haifa, Israel (Hebrew).

2015 Wall Paintings in the Synagogue of Rehov: An Account of Their Discovery. Israel Museum Studies in Archaeology 7: 2-12.

Weiss, Z.

2005 The Sepphoris Synagogue: Deciphering an Ancient Message through Its Archaeological and Socio-Historical Contexts. Jerusalem: Israel Exploration Society; Institute of Archaeology, Hebrew University of Jerusalem.

Weiss, Z., and Talgam, R.

2002 The Nile Festival Building and Its Mosaics: Mythological Representations in Early Byzantine Sepphoris. Pp. 55-90 in The Roman and Byzantine Near East, Vol. 3: Late Antique Petra, Nile Festival Building at Sepphoris, Deir Qal'a Monastery, Khirbet Qana Village and Pilgrimage Site, 'Ain-'Arrub Hiding Complex, and Other Studies, ed. J. H. Humphrey. Journal of Roman Archaeology Supplementary Series 49. Portsmouth, RI: Journal of Roman Archaeology.

Werlin, S. H.

2015 Ancient Synagogues of Southern Palestine, 300-800 C.E.: Living on the Edge. Brill Reference Library of Judaism 47. Leiden: Brill.

Wharton, A. J.

1994 Good and Bad Images from the Synagogue of Dura Europos: Contexts, Subtexts, Intertexts. Art History 17: 1-25.

1995 Refiguring the Post Classical City: Dura Europos, Jerash, Jerusalem and Ravenna. Cambridge: Cambridge University Press.

Wilkinson, I. P.

2017 Micropalaeontological Applications in Archaeology: Mobility and Provenance. Pp. 143-58 in The Archaeological and Forensic Applications of Microfossils: A Deeper Understanding of Human History, ed. M. Williams, T. Hill, I. Bloomer, and I. P. Wilkin- son. Bath: Geological Society of The Micropalaeontological Society.

Wittkower, R.

1939 Eagle and Serpent: A Study in the Migration of Symbols. Journal of the Warburg Institute 2: 293325.

Yeivin, $\mathrm{Z}$.

1974 Inscribed Marble Fragments from the Khirbet Susiya Synagogue. Israel Exploration Journal 24: 201-9.

1989 Khirbet Susiya-The Bema and Synagogue Ornamentation. Pp. 93-98 in Ancient Synagogues in Israel: Third-Seventh Century CE; Proceedings of Symposium, University of Hafia [sic], May 1987, ed. R. Hachlili. BAR International Series 499. Oxford: B.A.R.

2004 The Synagogue at Eshtemoa' in Light of the 1969 Excavations. 'Atiqot 49: 59*-98* (Hebrew; English summary on pp. 155-58).

Yizhaq, M.; Mintz, G.; Cohen, I.; Khalaily, H.; Weiner, S.; and Boaretto, E.

2005 Quality Controlled Radiocarbon Dating of Bones and Charcoal from the Early Pre-Pottery Neolithic B (PPNB) of Motza (Israel). Radiocarbon 47: 193206.

Zangenberg, J. K.; Münger, S.; Hakola, R.; Bonnie, R.; and Wyssmann, P.

2013a Horbat Kur-2011. Hadashot Arkheologiyot-Excavations and Surveys in Israel 125. http://www. hadashot-esi.org.il/report_detail_eng.aspx?id= 2230\&mag_id=120 (accessed May 22, 2018).

Zangenberg, J. K.; Münger, S.; Hakola, R.; and McCane, B. R.

2013b The Kinneret Regional Project Excavations of a Byzantine Synagogue at Horvat Kur, Galilee, 20102013: A Preliminary Report. Hebrew Bible and Ancient Israel 2: 557-76.

Zanker, P., and Ewald, B. C.

2012 Living with Myths: The Imagery of Roman Sarcophagi. Trans. J. Slater, from German. Oxford Studies in Ancient Culture and Representation. Oxford: Oxford University Press.

Zori, N.

1966 The House of Kyrios Leontis at Beth Shean. Israel Exploration Journal 16: 123-34. 